I N T ER N ATIONAL MONETARY FUND

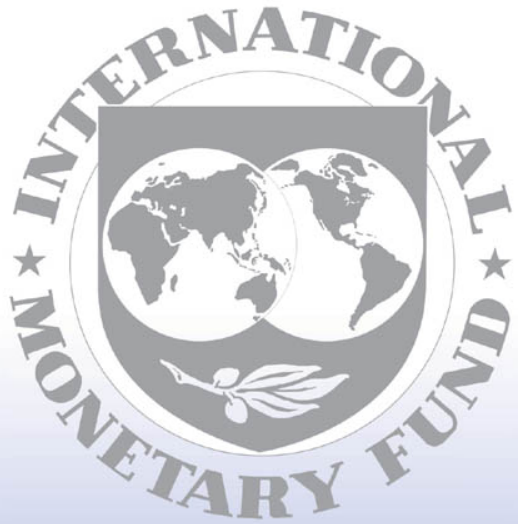

Staff

Country

Reports 


\section{Japan: Economic and Policy Developments}

This Economic and Policy Developments Paper on Japan was prepared by a staff team of the International Monetary Fund as background documentation for the periodic consultation with the member country. It is based on the information available at the time it was completed on July 18, 2001. The views expressed in this document are those of the staff team and do not necessary reflect the views of the government of Japan or the Executive Board of the IMF.

The policy of publication of staff reports and other documents by the IMF allows for the deletion of market-sensitive information.

To assist the IMF in evaluating the publication policy, reader comments are invited and may be sent by e-mail to Publicationpolicy@imf.org.

Copies of this report are available to the public from

International Monetary Fund - Publication Services

70019 th Street, N.W. - Washington, D.C. 20431

Telephone: (202) 6237430 - Telefax: (202) 6237201

E-mail: publications@imf.org • Intemet: http://www.imf.org

Price: $\$ 15,00$ a copy

\section{International Monetary Fund \\ Washington, D.C.}


This page intentionally left blank

CInternational Monetary Fund. Not for Redistribution 


\section{INTERNATIONAL MONETARY FUND}

\section{JAPAN}

\section{Economic and Policy Developments}

Prepared by T. Callen, M. Mühleisen,

S. Kalra, and T. Nagaoka (all APD)

Approved by the Asia and Pacific Department

July 18,2001

Contents

Page

Selected Economic Indicators, 1993-2001 4

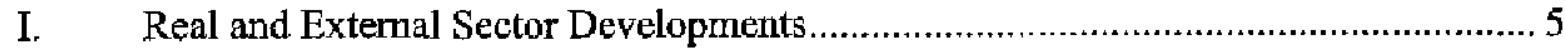

A. Real Sector Developments in 1999......................................................

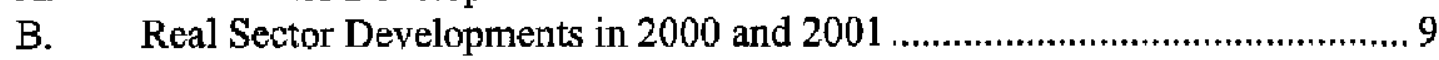

C. The Output Gap and Prices ...................................................................... 14

D. The Labor Market .................................................................................. 15

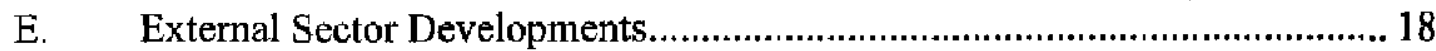

F. Statistical Issues .............................................................................. 20

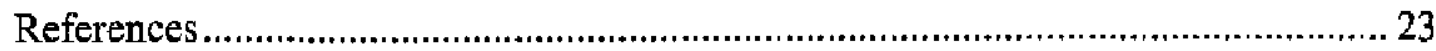

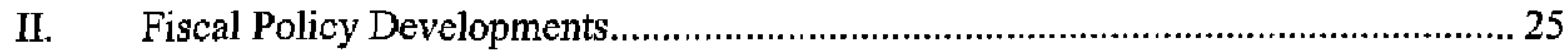

A. Budget Policies ...................................................................................... 25

B. Fiscal Investment and Loan Program .......................................................... 35

C. Fiscal Reforms ................................................................................. 38

D. Medium-term Fiscal Sustainability .........................................................42

References..................................................................................................... 46

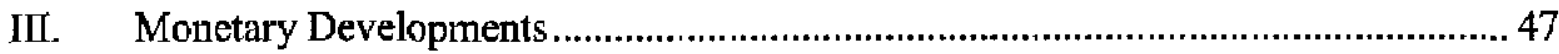

A. Policy Developments .........................................................................47

B. Interest Rates and Monetary Stance............................................................. 49

C. $\quad$ Money and Credit ...................................................................................5

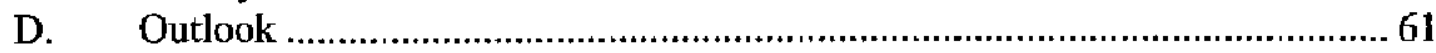

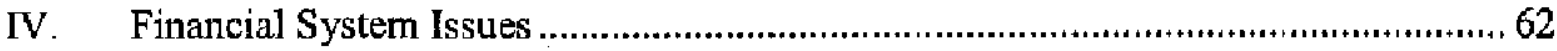

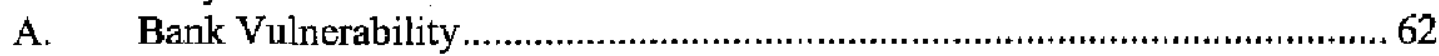

B. Policies to Strengthen the Banking System ...........................................73

C. Restructuring in the Banking and Insurance Sector....................................77

D. Remaining Challenges ............................................................................... 80

CInternational Monetary Fund. Not for Redistribution 


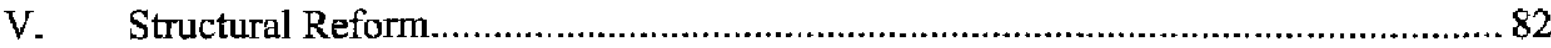

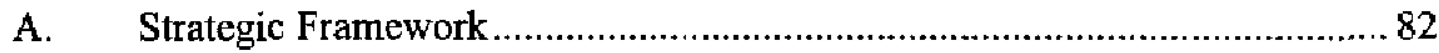

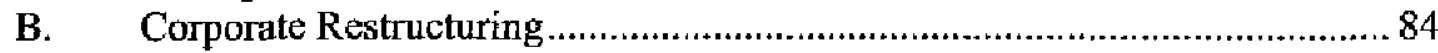

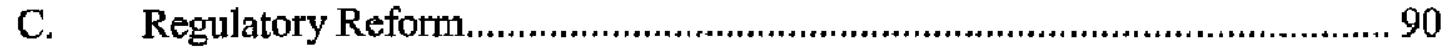

D. Administrative Reform m

E. Information Technology Issues............................................................. 95

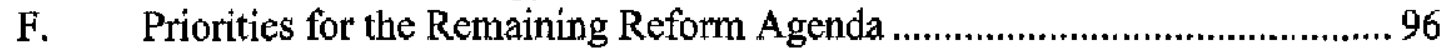

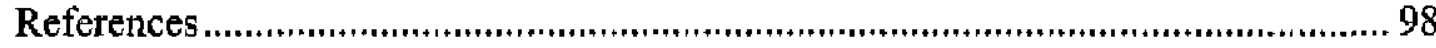

VI. Trade Policy and Economic Assistance.

References ............................................................................................................ 100

\section{Text Boxes}

I.1. The Impact of the IT Sector on Recent Economic Developments.......................... 11

TV.1 Japan--Methods to Estimate Future Bank Loan Losses .........................................6. 67

V.1. Blueprint for the Structural Reform of the Japanese Economy ................................ 83

V.2. Reorganization of Central Government ................................................................ 93

\section{Eigures}

I.1. Gross Domestic Product at 1995 Prices, 1990-2001 …….................................... 6

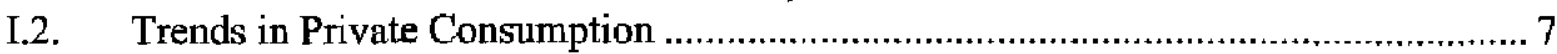

3. Indicators of Business Activity and Investment, 1990-2001 ............................... 8

I.4. Residential Investment and Inventory Investment, 1990-2001 .......................... 10

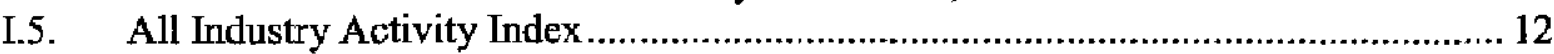

L.6. Information Technology Indicators, 1997-2001 …........................................... 13

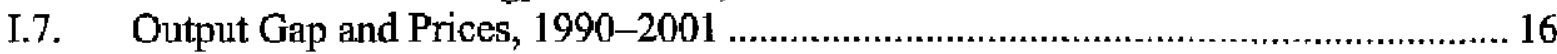

I.8. Labor Market Conditions, 1990-2001 _....................................................... 17

I.9. $\quad$ External Sector Developments, 1990-2001 _.................................................. 19

I.10. Growth and Volatility Comparisons ................................................................ 22

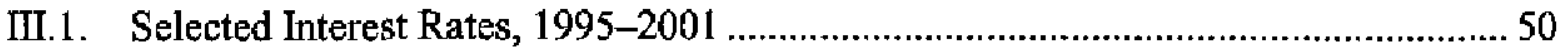

III.2. Funding Conditions for the Domestic Nonfinancial Sector.................................52

III.3. Monetary Policy Stance, 1995-2001 ............................................................53

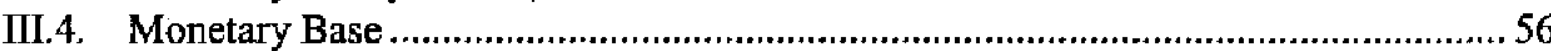

III.5. Money and Credit Growth, 1995-2001 ........................................................58

III.6. Developments in Money Multipliets, 1990-2001 .............................................6 60

TV.1. Major Banks' Profits, FY1990-2000 ……............................................................... 71

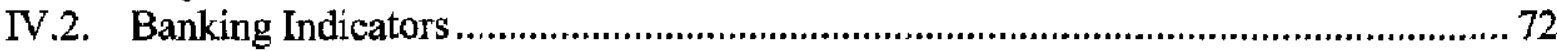

V.1. Selected Indicators of Business Conditions, 1980-2001 _................................... 86

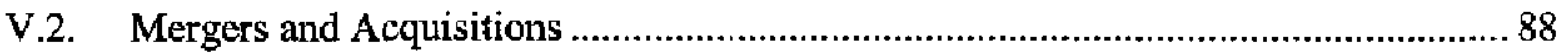

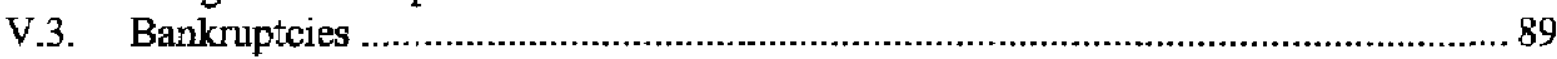


Tables

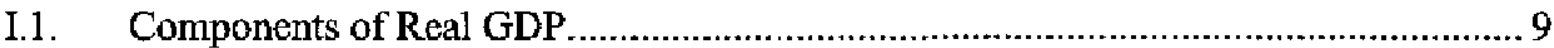

II.1. Central Government General Account Budget, FY1996-2001 ….......................... 27

II,2. Tax Receipts of the Central Government General Account, FY1996-2001 ............28

II.3. Summary of Economic Stimulus Packages, 1993-2000 ….............................. 29

II.4. Central Government Bond Issues, FY1999-2001 .......................................... 30

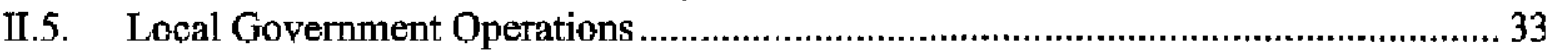

II.6. General Government Public Works Projects ................................................ 34

II.7. General Government Operations, 1998-2002 …........................................... 35

II.8. $\quad$ Fiscal Investment and Loan Program (FELP), FY1996-2001 _........................... 37

II.9. General Government Finances, 2000 .............................................................. 42

II.10. Baseline Scenario for Medium-Term Debt Consolidation ........................................ 45

III.1. Monetary Base and the Bank of Japan's Transactions (Flow Table) ....................... 54

III.2. Monetary Survey ...............................................................................................57

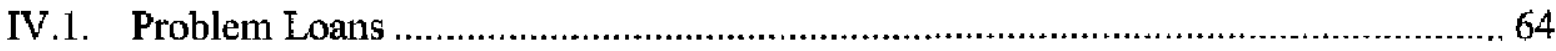

IV.2. Classification of Bank Loans ,......................................................................... 65

IV.3. Sensitivity Analysis for Uncovered Loan Losses of Major and Regional Banks...... 69

IV.4. Bank Support Framework ................................................................................. 77

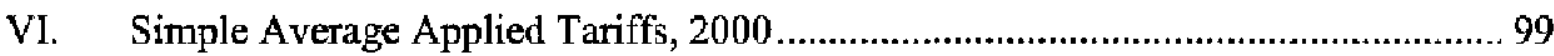


Table 1. Japan: Selected Economic Indicators, 1994-2002

Population: 126.9 million (2000)

GDP per capita: US\$37.470 (2000)

Quota: SDR 8,241.5 million

\begin{tabular}{|c|c|c|c|c|c|c|c|c|c|}
\hline \multirow{2}{*}{ 每 } & \multirow[b]{2}{*}{1994} & \multirow[b]{2}{*}{1995} & \multirow[b]{2}{*}{1996} & \multirow[b]{2}{*}{1997} & \multirow[b]{2}{*}{1998} & \multirow[b]{2}{*}{1999} & \multirow[b]{2}{*}{2000} & \multicolumn{2}{|l|}{ Proj. } \\
\hline & & & & & & & & 2001 & 2002 \\
\hline \multicolumn{10}{|l|}{ Growth (percent change) } \\
\hline Real GDP & 1.0 & 1.6 & 3.3 & 1.9 & .1 .1 & 0.8 & 1.5 & -0.2 & 0.5 \\
\hline Domestic demand & 1.3 & 2.1 & 3.8 & 1.0 & -1.4 & 0.9 & 1.1 & 0.3 & 0.2 \\
\hline Private consumption & 2.5 & 1.5 & 1.9 & 1.1 & 0.2 & 1.2 & 0.5 & 0.2 & 0.8 \\
\hline Residential investment & 7.4 & .5 .8 & 13.4 & -15.3 & -13.9 & 0.8 & 1.6 & -4.0 & 0.6 \\
\hline Business investment & -6.5 & 2.5 & 4.2 & 13.2 & -2.3 & -4.3 & 4.4 & 1.6 & 1.7 \\
\hline Government consumption & 2.8 & 4.3 & 2.8 & 1.3 & 1.9 & 4.0 & 3.6 & 2.0 & 1.7 \\
\hline Public investment & 3.6 & .0 .3 & 9.3 & -10.4 & -2.6 & 6.1 & -7.3 & -4.1 & -12.2 \\
\hline Stockbuilding $1 /$ & -0.2 & 0.6 & 0.3 & 0.0 & -0.6 & -0.2 & 0.1 & 0.1 & 0.0 \\
\hline Net exports $\mathrm{i} /{ }^{\circ}$ & -0.2 & -0.5 & -0.4 & 1.0 & 0.3 & -0.1 & 0.4 & -0.5 & 0.3 \\
\hline Exports of goods and services & 3.4 & 4.1 & 6.4 & 11.3 & -2.3 & 1.3 & 12.1 & -2.9 & 5.4 \\
\hline Imports of goods and services & 7.7 & 12.8 & 13.2 & 1.2 & -6.8 & 2.9 & 9.9 & 2.4 & 3.0 \\
\hline \multicolumn{10}{|l|}{ Saving-Investment (percent of GDP) } \\
\hline Gmoss national saving & 30.7 & 30.2 & 30.6 & 30.9 & 29.9 & 28.6 & 28.5 & 28.1 & 27.6 \\
\hline Gross domestic investment & 28.1 & 28.2 & 29.2 & 28.7 & 26.9 & 25.9 & 26.0 & 25.7 & 24.8 \\
\hline \multicolumn{10}{|l|}{ Inflation (antiual average) } \\
\hline CPI & 0.7 & -0.1 & 0.1 & 1.7 & 0.6 & -0.3 & -0.6 & -0.7 & -0.7 \\
\hline GDP deflator & 0.1 & -0.4 & -0.6 & 0.3 & -0.1 & -1.4 & -1.7 & -0.9 & -1.1 \\
\hline Unemployment rate (annual average) & 2.9 & 3.1 & 3.3 & 3.4 & 4.1 & 4.7 & 4.7 & 5.0 & 5.5 \\
\hline \multicolumn{10}{|l|}{ Government (percent of GDP) } \\
\hline Revenue & 31.2 & 31.1 & 31.0 & 30.8 & 30.5 & 30.1 & 30.4 & 30.4 & 30.3 \\
\hline Expenditure & 33.5 & 34.6 & 35.2 & 34.1 & 35.0 & 36.9 & 38.3 & 37.3 & 36.3 \\
\hline Balance & -2.2 & -3.5 & $.4,2$ & -3.2 & -4.5 & -6.8 & -8.0 & -6.9 & -6.0 \\
\hline Balance excluding social secunty & -5.0 & -6.3 & -6.7 & -5.8 & -6.5 & -8.6 & -9.2 & .7 .7 & -6.5 \\
\hline Structural balance $2 J$ & -1.9 & -3.2 & -4.3 & -3.4 & -3.6 & -5.4 & -5.5 & -5.2 & -4.1 \\
\hline \multicolumn{10}{|l|}{ Money and credit (percent change, end-pericd) } \\
\hline M2 plus CDs & 2.9 & 3.2 & 2,9 & 3.8 & 3.9 & 2.6 & 2.2 & $3.24 J$ & $\ldots$ \\
\hline Eroad liquidity & 3.7 & 4.1 & 3.5 & 3.3 & 3.1 & 2.4 & 3.2 & 3.051 & $\ldots$ \\
\hline Dornestic credit & -0.4 & 1.8 & 1.4 & 1.3 & 2.6 & 2.9 & 2.6 & 4.561 & $\ldots$ \\
\hline Bank lending & -0.2 & 2.1 & -0.4 & 0.0 & -4.7 & -5.9 & -3.8 & $-3.84 /$ & $\cdots$ \\
\hline \multicolumn{10}{|l|}{ Interest rate } \\
\hline Three-month CD rate (annual average) & 2.1 & 1.1 & 0.5 & 0.5 & 0.6 & 0.1 & 0.2 & 0.017 & $\ldots$ \\
\hline Official discount rate (end-period) & 1.8 & 0.5 & 0.5 & 0.5 & 0.5 & 0.5 & 0.5 & 0.2571 & $\cdots$ \\
\hline \multicolumn{10}{|l|}{ Balance of payments (in billions of US\$) } \\
\hline Exports, f.o.b. & 386.0 & 429.4 & 400.2 & 409.2 & 374.4 & 403.9 & 459.6 & 428.0 & 460.1 \\
\hline Imports, f.o.b. & 241.5 & 297.2 & $\$ 16.7$ & 307.8 & 251.6 & 280.5 & 342.8 & 333.3 & 345.2 \\
\hline Cument account balance & 130.6 & $1 \mathrm{t} 1.4$ & 65.8 & 94.1 & $\$ 21.0$ & 106.8 & 116.9 & 102.2 & 118.4 \\
\hline Percent of GDP & 2.7 & 2.1 & 1.4 & 22 & 3.1 & 2.4 & 2.5 & 2.4 & 2.8 \\
\hline Temss of trade (percent change) & 7,1 & 0.5 & -6.9 & -3.9 & 6.7 & 4.7 & -5.1 & -0.8 & -0.7 \\
\hline Change in reserves & 25.4 & 58.7 & 36.8 & 6.9 & -7.4 & 77.3 & 49.3 & ... & $\ldots$ \\
\hline Total reserves minus gold (in billions of US\$) & 125.9 & 183.2 & 216.6 & 219.6 & 215.5 & 286.9 & 354.9 & $356.04 d$ & $\ldots$ \\
\hline \multicolumn{10}{|l|}{ Exchange rates (annual average) } \\
\hline Yen/dollar rate & 102.2 & 94.1 & 108.8 & 121.0 & 130.9 & 113.9 & 107.8 & 125.37 & $\ldots$ \\
\hline Real effective exchange rate 3 / & 143.5 & 149.5 & 126.7 & 117.8 & 107.4 & 120.1 & 127.4 & $120.44 \delta^{\prime}$ & $\ldots$ \\
\hline
\end{tabular}

Sources: Nikkei Telecom; and staff estimates and projections as of July 3, 2001,

1/ Contribution to GDP growth.

y/ Including social security, excluding bank support.

3 / Based on normalized unit labor costs; $1990=100$.

4/ June 2001.

5/ May 2001 .

6/ April 2001.

$7 /$ July $18,2001$. 


\section{REAL AND External Sector Developments ${ }^{1}$}

1. The legacy of the collapse of the asset price bubble and the failure of the bank and corporate sectors to reduce the excess debt and capital built-up during the 1980s continue to weigh on the Japanese economy and make it vulnerable to external and domestic shocks. These vulnerabilities have been clearly evident in recent years as the economy has failed to turn temporary upturns into longer periods of self-sustaining growth. For example, the recovery in 1996 gave way to a severe downzurn in 1998-with real GDP declining by 1 percent - as the government withdrew fiscal stimulus, concerns about the health of the banking system following the closure of three financial institutions burt confidence, and the Asia financial crisis adversely impacted external demand. Following the moderate recovery that began in 1999, the economy has again stumbled since the middle of 2000 as the downturn in the world economy and the global electronics market undermined exports and investment. With real GDP contracting in the first quarter of 2001, there is again considerable concern about the short-term outlook for the Japanese economy.

2. This chapter discusses economic developments since 1999. It emphasizes that the recovery from the 1998 recession was unbalanced, initially being based on a large fiscal stimulus and subsequently on the strength of the global economy and the booming world electronics market. The failure of domestically-driven private demand, particularly consumption, which accounts for over 50 percent of GDP, to support growth has meant that the economy faltered as the positive impact of these factors dissipated. Consequently, until the factors that are currently constraining private expenditure-including uncertainty about bank and corporate restructuring and questions about long-term fiscal sustainability--are decisively dealt with, a self-sustaining recovery is likely to continue to prove elusive.

\section{A. Real Sector Developments in 1999}

\section{A strong expansion of public sector demand underpinned a modest economic} recovery during 1999 . Following the 1998 recession, real GDP grew by $3 / 4$ of a percent in 1999, while the all-industries production index - the best supply-side proxy for real GDP-.increased by 1 percent. A return to an expansionary fiscal stance resulted in public consumption and investment growing strongly, by 4 percent and 6 percent, respectively, with public demand contributing 1 percentage point to GDP growth (Figure I.1). However, private demand continued to subtract from growth. Private consumption rebounded modestly as consumer confidence improved following official intervention to address the problems in the financial sector, but this was offset by a further decline in business investment and stockbuilding (Figures I.2 and I.3). The contribution from the external sector also turned negative as exports continued to be affected by the aftermath of the Asia financial crisis, but imports picked-up with the domestic recovery and the continued rise in import penetration of Japanese markets.

\footnotetext{
${ }^{1}$ Prepared by Tim Callen (ext. 38873).
} 
Figure I.1. Japan: Gross Domestic Product at 1995 Prices, 1990-2001
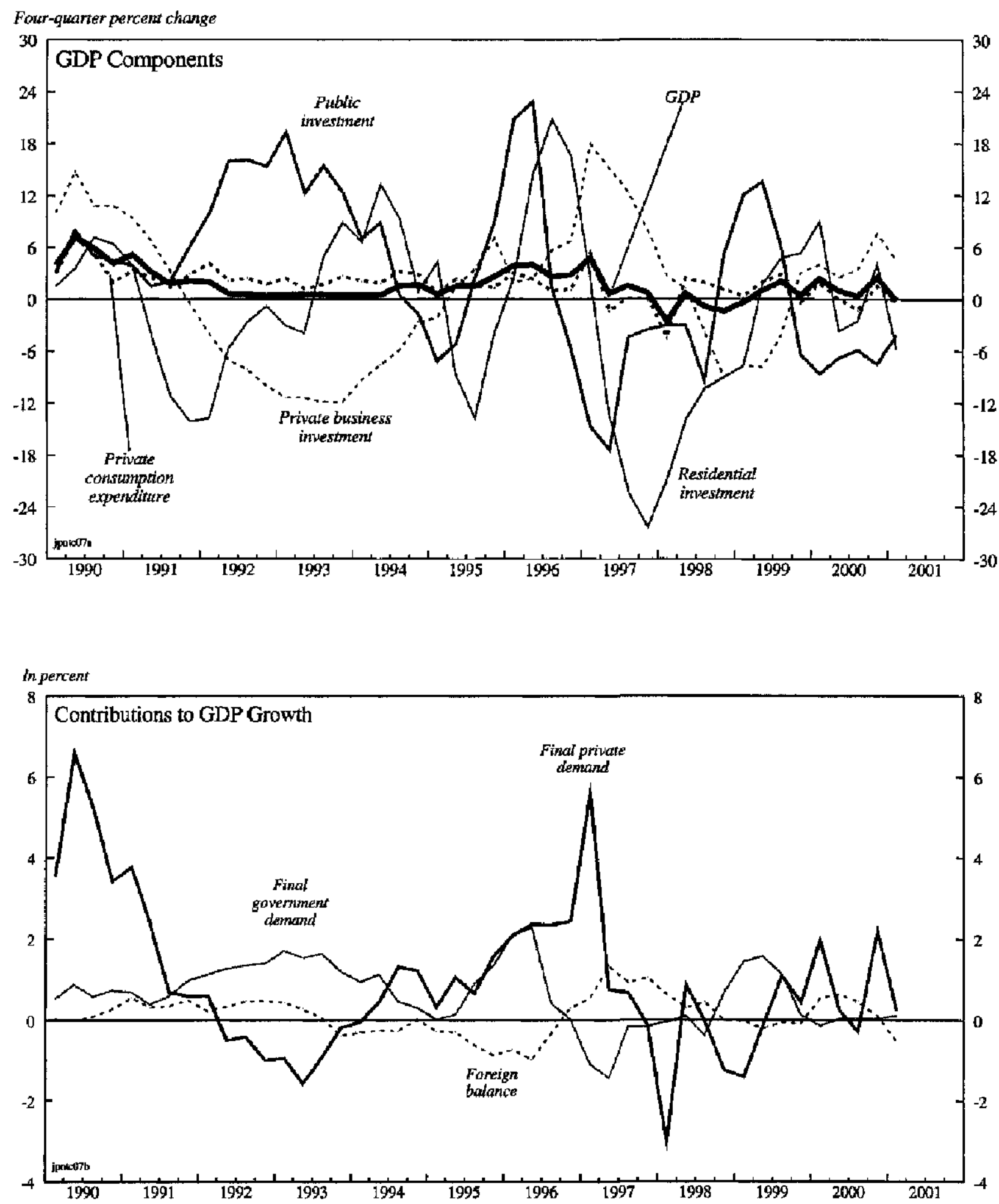

Soures: Nikkei Telecom; and WEFA. 
Figure I.2. Japan: Trends in Private Consumption
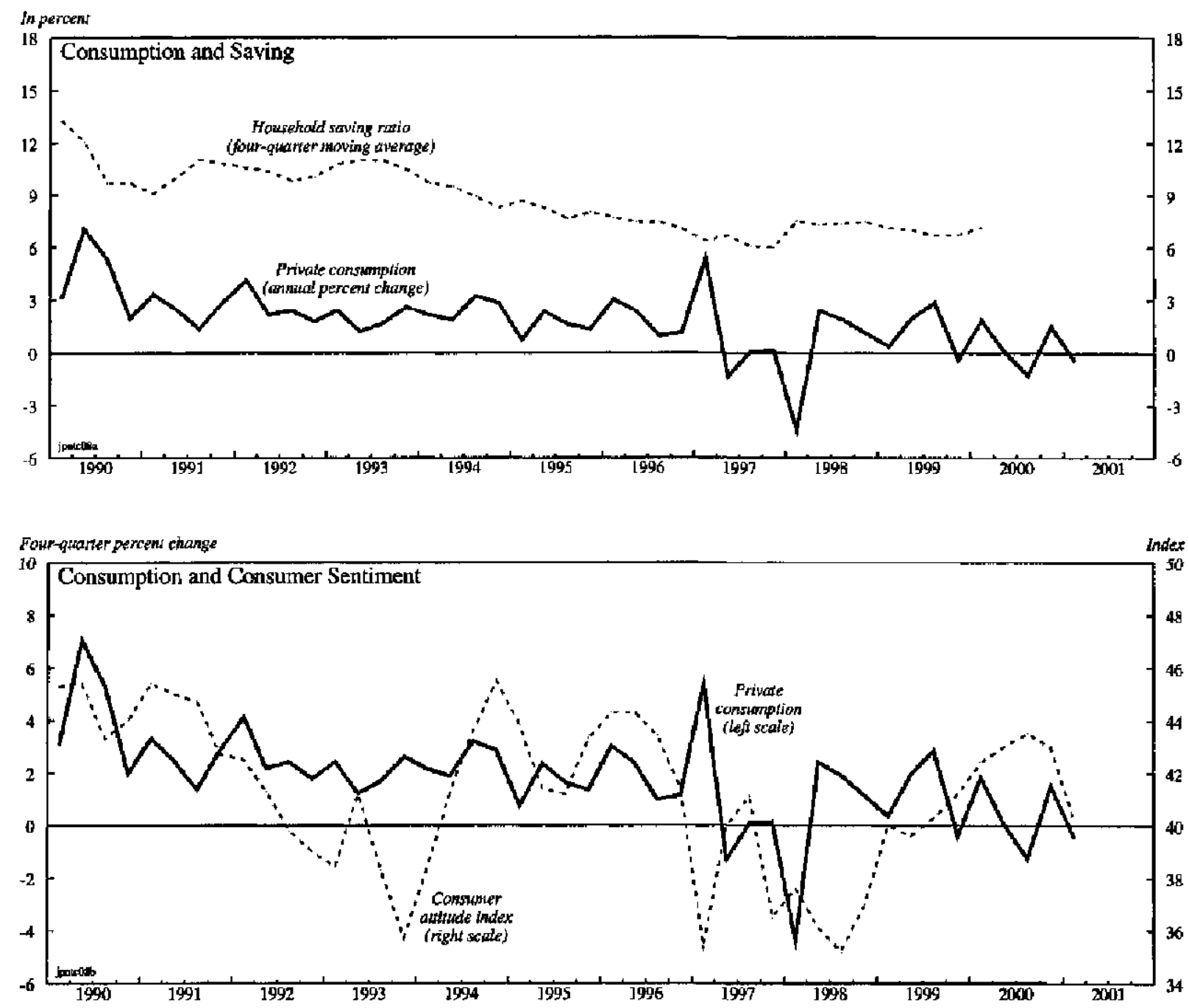

Percent of disposable income

Percent of digposoble income

1000 Household Net Worth and Liabilities

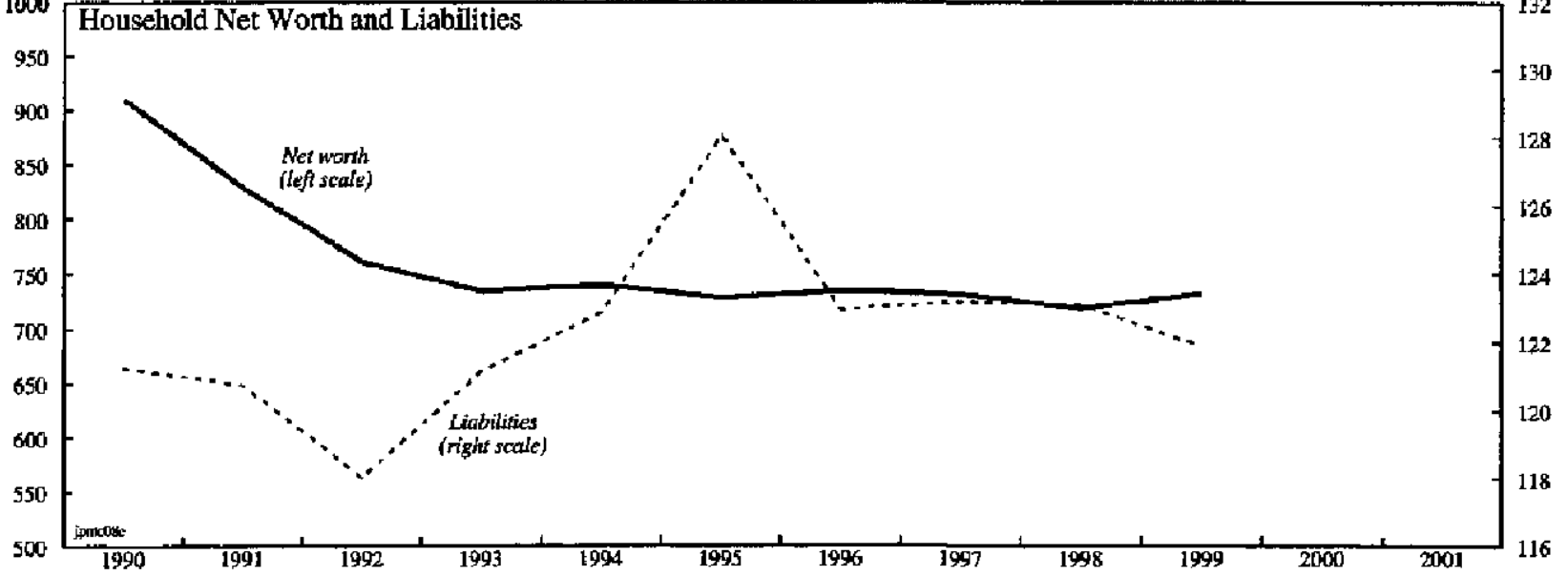

Sources: Nikkei Telecom; and WEFA, Nomttra Database. 
Figure I.3. Japan: Indicators of Business Activity and Investment, 1990-2001
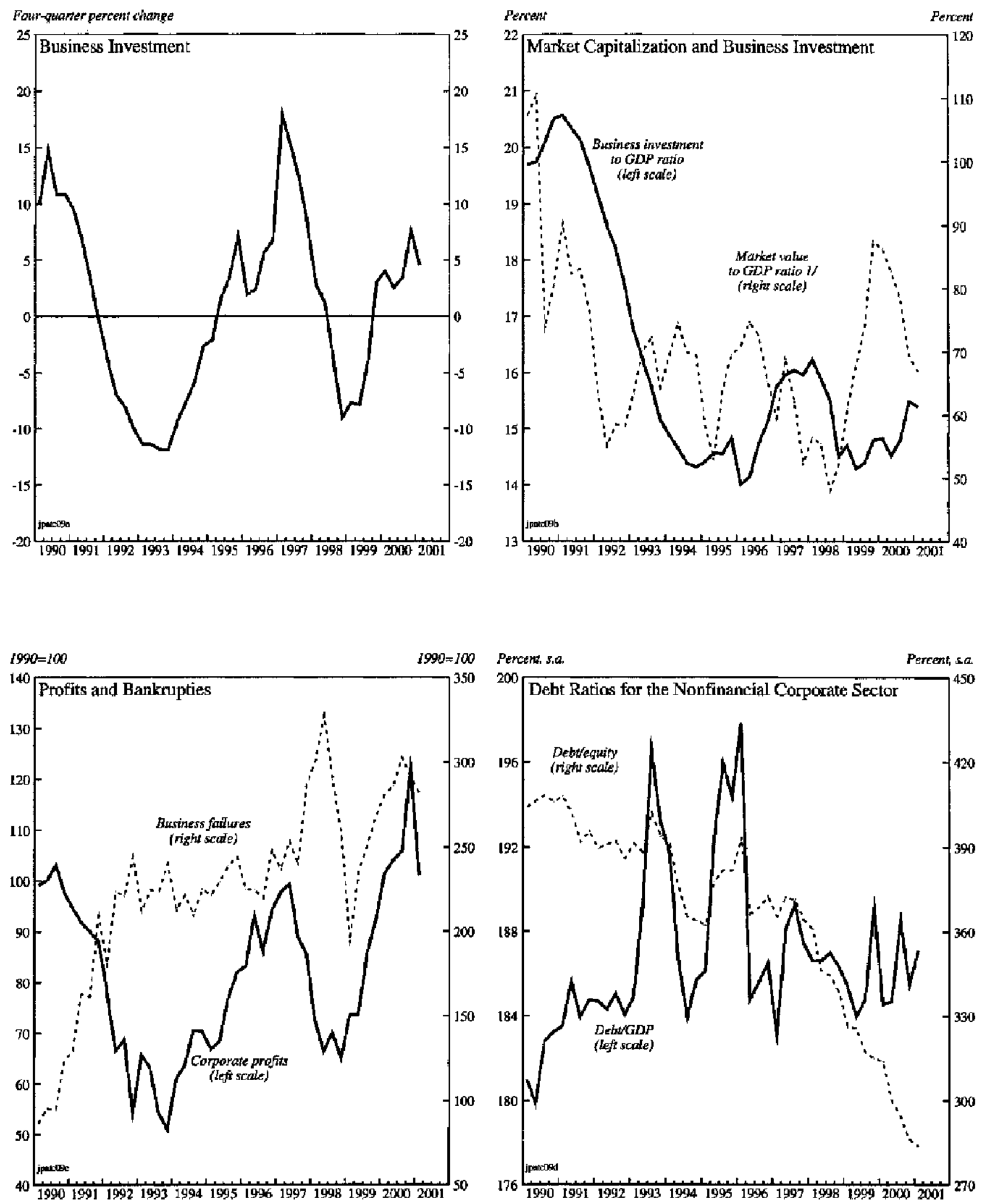

Sources: Nikkei Telacom; and WEFA, Nomura Database.

1/ TSE stack market value in percent of GDP. 
4. Growth, however, was largely concentrated in the first half of the year (Table 1.1). The fiscal stimulus packages of $¥ 17$ trillion in April 1998 and $¥ 24$ trillion in November 1998 had a particularly large impact in the first half of 1999. Public investment grew by 12 percent relative to the second half of 1998, and residential investment also increased robustly, rising by $31 / 4$ percent, in response to the increase in tax credits for housing loans introduced in the FY 1999 budget (Figure I.4). However, private consumption remained subdued, while business investment and net exports declined.

\begin{tabular}{|c|c|c|c|c|c|c|c|c|c|c|c|}
\hline \multicolumn{12}{|c|}{ Table I.1. Components of Real GDP } \\
\hline & \multirow[t]{2}{*}{1998} & \multirow[t]{2}{*}{1999} & \multirow{2}{*}{2000} & \multicolumn{2}{|c|}{1999} & \multicolumn{2}{|c|}{2000} & \multicolumn{3}{|c|}{2000} & \multirow{2}{*}{$\frac{2001}{Q 1}$} \\
\hline & & & & H1 & H2 & H1 & H2 & $\mathrm{Q}^{2}$ & $Q^{3}$ & Q4 & \\
\hline & \multicolumn{11}{|c|}{ (Percent change from previous period, unless otherwise stated) } \\
\hline Real GDP & -1.1 & 0.8 & 1.5 & 1.3 & .0 .1 & 1.7 & -0.3 & 0.1 & -0.7 & 0.6 & -0.2 \\
\hline Private consumption & 0.2 & 1.2 & 0.5 & 0.6 & 0.6 & 0.3 & -0.2 & 0.1 & 0.0 & -0.6 & 0.0 \\
\hline Private business investment & -2.3 & -4.3 & 4.4 & -2.0 & 1.4 & 1.9 & 3.6 & -2.5 & 1.5 & 6.7 & -1.0 \\
\hline Residential investment & -13.9 & 0.8 & 1.6 & 3.3 & 1.7 & 0.7 & 0.0 & -5.3 & 0.5 & 4.5 & -5.2 \\
\hline Government consumption & 1.9 & 4.0 & 3.6 & 2.3 & 2.0 & 1.8 & 1.6 & 1.2 & 0.5 & 0.9 & 0.0 \\
\hline Public investment & -2.6 & 6.1 & -7.3 & 12.1 & -11.3 & 4.1 & -10.4 & 4.0 & -11.9 & -0.6 & 5.2 \\
\hline Change in stocks (contribution) & -0.6 & -0.2 & 0.1 & 0,1 & $-0,1$ & 0.2 & 0.0 & 0.1 & 0.0 & 0.0 & 0.0 \\
\hline Net exports (contribution) & 0.3 & -0.1 & 0.4 & -0.2 & 0.1 & 0.5 & -0.2 & 0.1 & -0.1 & -0.4 & -0.2 \\
\hline Exports of goods and services & -2.3 & 1.3 & 12.1 & -0.2 & 5.0 & 8.0 & 2.6 & 4.0 & 0.2 & 0.8 & -3.6 \\
\hline Imports of goods and services & -6.8 & 2.9 & 9.9 & 2.1 & 5.0 & 4.2 & 5.9 & 3.9 & 1.3 & 5.1 & -2.2 \\
\hline
\end{tabular}

5. As the impact of the large fiscal stimulus waned in the second half of the year, the economy stalled. As has been the case in recent years, public investment fell sharply in the third quarter of 1999 by $12^{3 / 4}$ percent and residential investment also slowed as the initial surge in demand following the introduction of the tax incentives eased. However, at the same time, there were signs of a pick-up in other components of private demand. As corporate profits rebounded, business investment began to recover in the third quarter, and surged by $2 \frac{1}{2}$ percent (quarterly rate) in the fourth quarter. Private consumption also rose modestly in the second half of 1999 despite a large, and difficult to explain, $31 / 4$ percent (quarterly rate) slump in the fourth quarter (other indicators of consumption-such as shipments of consumer goods for domestic use, sales at large retail stores, and registrations of new passenger vehicles-did not suggest a large decline, raising the possibility that consumption may have been under-recorded in the national accounts). Further, with the lagged impact of the weakening of the yen during 1998 and the strengthening of the world economy resulting in a considerable acceleration in export growth, the contribution from the external sector turned positive in the second half of the year, despite some acceleration in import growth in the fourth quarter as preparations were made for potential supply disruptions over the new year period.

\section{B. Real Sector Developments in 2000 and 2001}

6. On the back of the buoyant world economy and global electronics market, the economy strengthened in early 2000 , and for the year as a whole real GDP grew by $1 \frac{1}{2}$ percent. Again, however, growth was not broad-based, with the principal drivers being 
Figure I.4. Japan: Residential Investment and Inventory Investment, 1990-2001
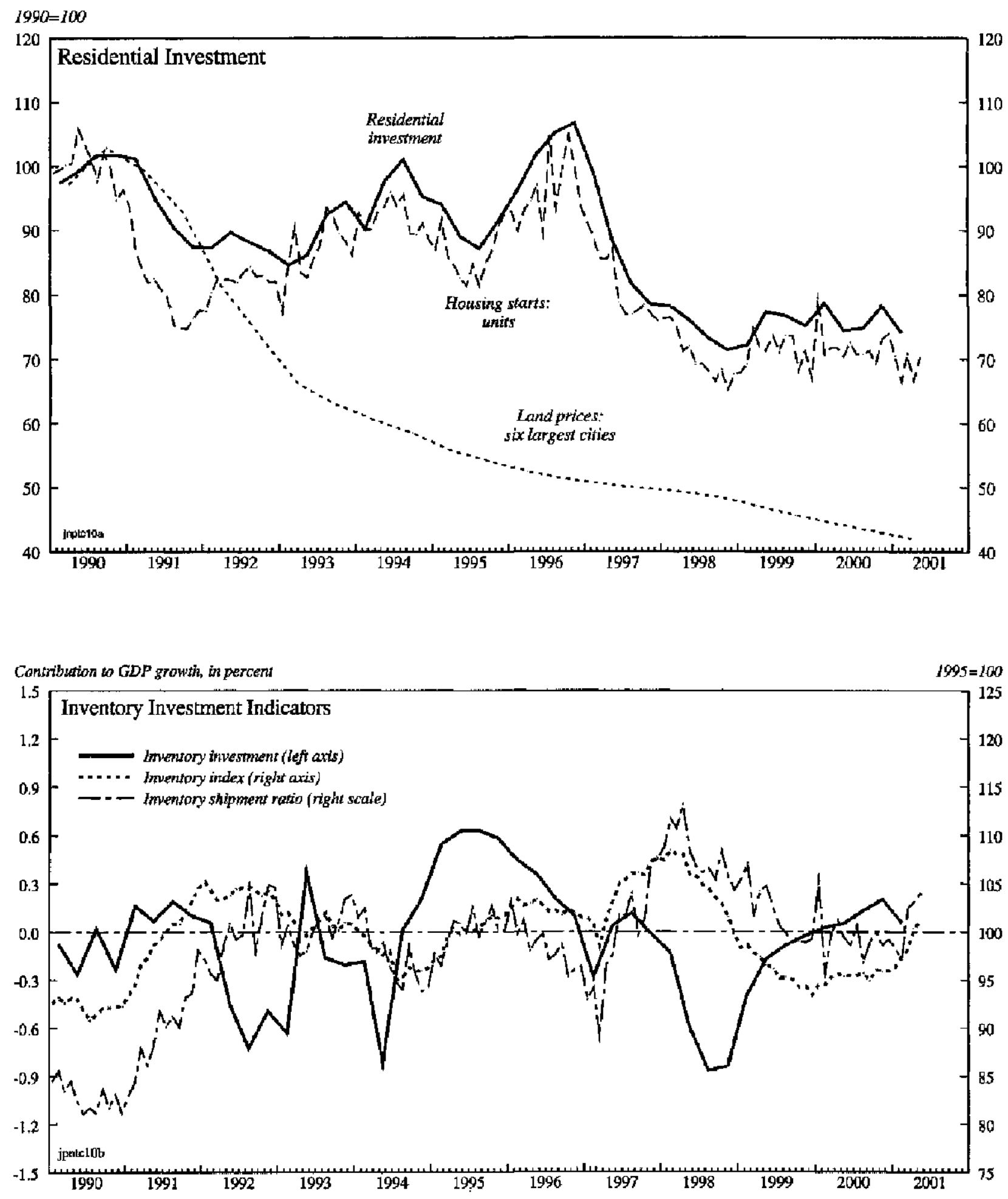

Soumes: Nikki Talecom; WEFA, Nomura Database; and siaft estimates. 
business investment ( $3 / 4$ percentage point contribution) and net exports ( $1 / 2$ percentage point contribution), while the other components of demand made small or zero contributions.

7. Growth was again concentrated in the first half of the year. With the growth of the global electronics market peaking at around 50 percent ( $y / y$ in nominal terms) in the second quarter of 2000 , demand for electrical machinery products grew strongly and underpinned robust export growth. Further, as the stocks that had accumulated in late 1999 were wound down, import growth was subdued, and consequently net exports contributed significantly to growth. Business investment also strengthened further - which had been foreshadowed by the sharp acceleration in machinery orders during the second half of 1999 -underpinned by robust corporate profit growth. A rebound in private consumption in the first quarter, following its fourth quarter slump, and the impact of the fiscal stimulus from the November 1999 supplementary budget also added to the growth momentum. For the year as a whole, however, public investment declined by $7 \frac{1}{4}$ percent, as the central government package was considerably smaller than in 1998, while the local governments increasingly cut back their spending in an attempt to strengthen their finances (even with this decline, the ratio of public sector investment-to-GDP remained at over 7 percent, considerably higher than the 2-3 percent rates in the United States and Germany).

\section{In this environment, industrial production expanded rapidly, with growth} peaking at $83 / 4$ percent (12-month rate) in August 2000 (Figure I.5). Industrial shipments for exports were particularly strong, rising by $11 \frac{1 / 2}{2}$ percent (4-quarter rate) in the second quarter of 2000 . However, the strong production growth was largely attributable to the very rapid growth in the electrical machinery (22/2 percent, 12 -month rate) and industrial machinery sectors (141/4 percent, 12-month rate) (see Box I.1 for details of the role of the IT sector in recent years). However, highlighting the narrow base of the expansion, many other sectorsparticularly chemicals, transportation equipment, and food and tobacco-performed poorly. The expansion also did not spread to the same extent in the tertiary sector, and consequently growth of the all-industries production index peaked at a much lower rate- of $3 \frac{3 / 4}{4}$ percent in mid-2000.

\section{Box I.1: The Impact of the IT Sector on Recent Economic Developments}

The information technology (IT) sector contrlbuted significantly to growth during 2000 . As the global electronics market strengthened during the first half of 2000 , IT related production, exports, and investment all surged (Figure I.6). Growth in IT-related exports hit 50 percent (y/y) and IT-related production 25 percent $(y / y)$ during the first half of 2000 , and at their peak contributed around one-third and nearly one-half of the increase in overall exports and industrial production respectively. Orders for IT-related investment goods and new job offers in the IT-sector also surged. While, a less disaggregated breakdown is available for investment itself, the MOF corporate survey indicates that investment by the electrical machinery sector-a broad proxy for IT products - has also grown strongly, contributing around one-third of total investment during 2000.

However, growth in the IT-sector has slowed sharply since the third quarter of 2000. IT-related exports fell by 25 percent $(y / y)$ in April 2001 and IT production by 12 percent $(y / y)$, contributing significantly to the slowdown in aggregate exports and production. Likewise, new orders and job offers have slowed, although actual investment by the electrical machinery sector remained around 30 percent $(y / y)$ in the first quarter of 2001. 
Figure I.5. Japan: All Industry Activity Index
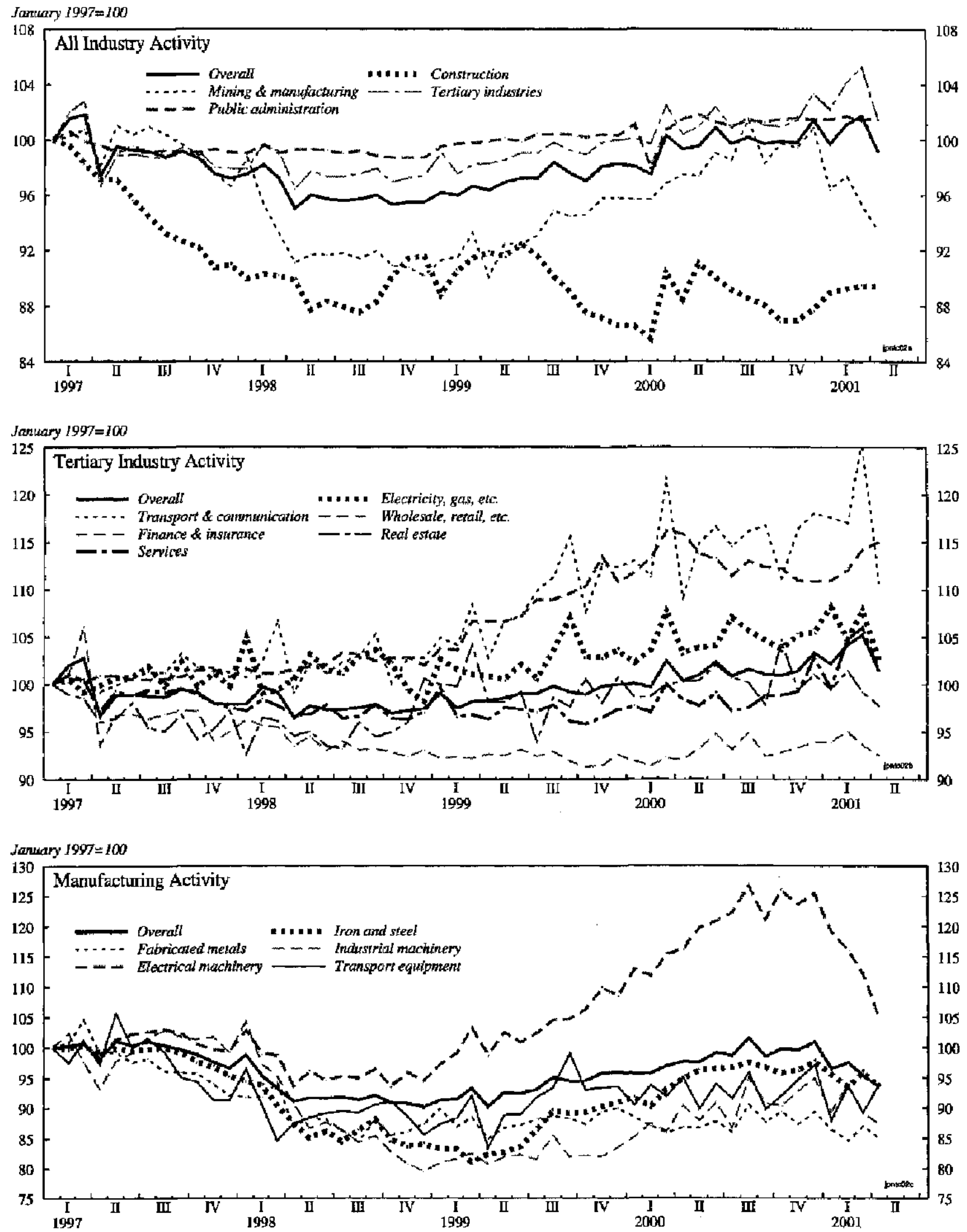

Source: CEIC databese. 
Figure I.6. Japan: Information Technology Indicators, 1997-2001 1/
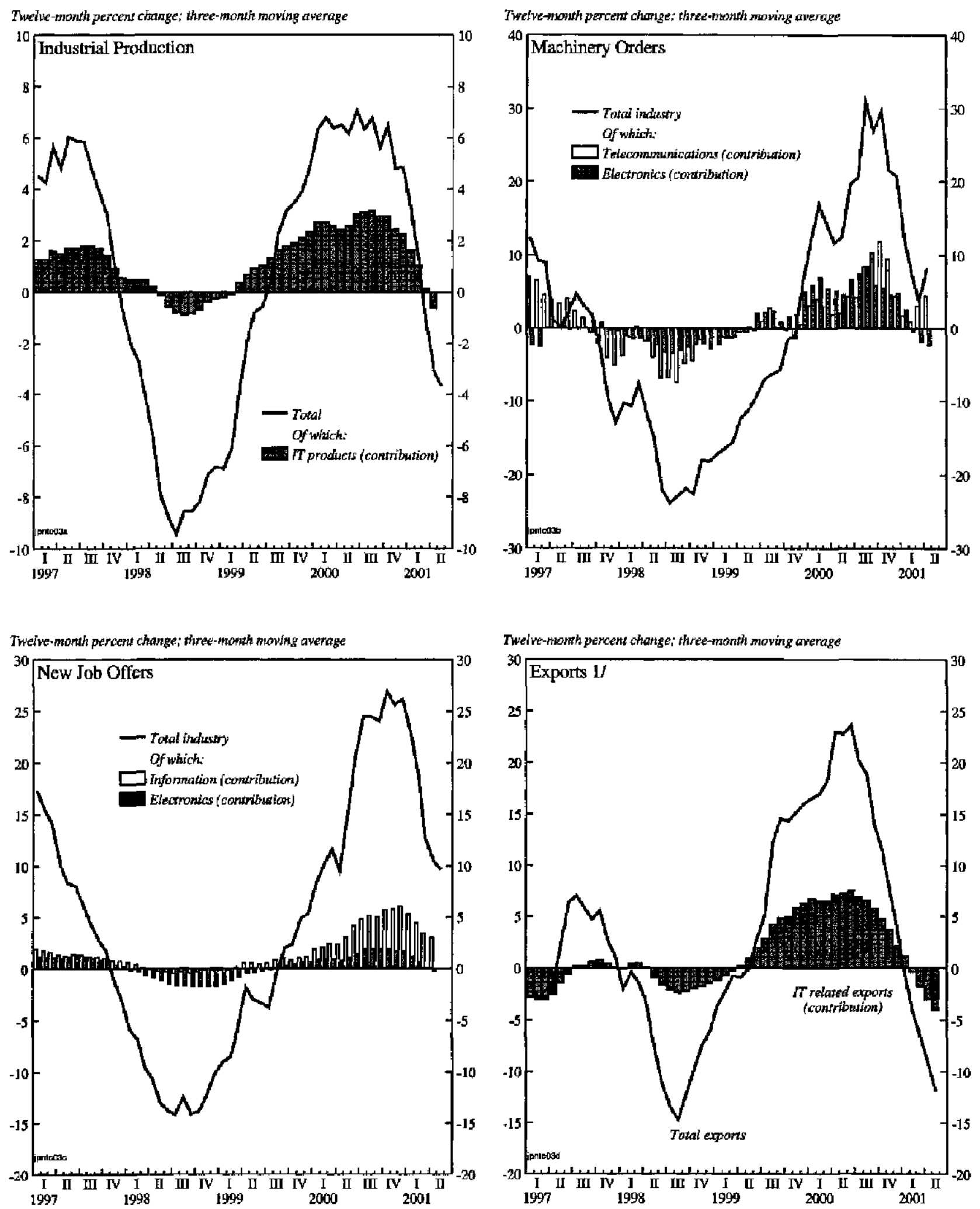

Sources: Ministry of Economy, Trade and Industry; Cablnat Office; and Minlstry of Finance, Jesan Tarit Assoclation.

1/ Custorns clearance basis; in U.S. dolar terms. 
9. However, the economy began to stall from the middle of the year as the external environment deteriorated, and activity turned down quite sharply at the beginning of 2001. Export growth slowed with the deterioration in the external environment-and the demand for IT-related products in particular - and the lagged impact of the appreciation of the yen during 1999. Import growth continued through the second half of 2000 , before turning down in early 2001 , and the contribution of net exports to growth turned significantly negative from the third quarter of 2000 .

10. Business investment initially remained robust, but has subsequently weakened. Despite evidence that the economy was slowing, business investment continued to expand quite strongly in the second half of 2000 - particularly in the fourth quarter-as the electrical machinery sector spent heavily and there was a surge in investment in the retail sector as businesses pushed to finish stores ahead of new regulations governing store sitings. However, from the fourth quarter, evidence that this growth would not be sustained was mounting. New machinery orders eased, and then fell sharply in the first quarter of 2001, while the deterioration in business conditions was clearly evident in the sharp slowing of corporate profits-according to the MoF Corporate Survey, profit growth declined to zero $(y / y)$ in the first quarter, from 32 percent ( $y / y$ ) growth in the previous quarter-and in the results of the March and June 2001 Tankan surveys. Business investment declined by 1 percent in the first quarter of 2001. Although investment in the manufacturing sector remained strong, led by the electrical machinery sector and new strength in transportation, this was more than offset by weaker spending in the nonmanufacturing sector, partly in response to the investment in the retail sector that had been brought forward into the fourth quarter.

11. Uncertainties about bank and corporate restructuring and their implications for job prospects, together with questions about the long-term fiscal situation, may have exacerbated the adverse impact of external developments on consumer confidence. Private consumption weakened during the second half of 2000 as households saved an increasing proportion of their income in light of the rising economic uncertainties, while monthly earnings also fell (see discussion in paragraph 17). Private consumption remained flat in the first quarter of 2001 despite a boost to purchases of consumer durables ahead of the introduction of a new recycling law on April 1, 2001 (which requires the payment of a disposal fee on the purchase of new household appliances). During this period, public investment continued to fluctuate widely, being sharply negative in the third quarter of 2000 as the impact of the November 1999 supplementary budget waned, but contributing strongly in the first quarter of 2001 as the measures in the November 2000 supplementary budget began to take effect.

\section{The Output Gap and Prices}

12. The output gap has widened since the middle of $\mathbf{2 0 0 0}$ as growth has slowed. Staff estimates from a Cobb-Douglas production function suggest that potential growth in Japan is currently around $1 \frac{1}{2}$ percent, although given the ongoing structural change in the economy 
there is considerable uncertainty around this estimate. ${ }^{2}$ Consequently, despite the return to growth in 1999, the output gap is estimated to have widened to around 3 percent (i.e. output was 3 percent below potential) (Figure I.7). After narrowing slightly in the first half of 2000 , the gap has again widened, and is estimated at around 4 percent in the first quarter of 2001 .

13. Deflationary pressures have continued. Having stabilized during the second half of 1999, the consumer price index excluding fresh food, fuel, water, and light-a measure of underlying prices - resumed its decline in early 2000 , and is currently falling by $1 / 2-3 / 4$ percent year-on-year (Figure I.7). Wholesale prices of domestic products have shown a similar recent trend. On the other hand, the headline CPI and WPI indices have been boosted by energy price developments and yen depreciation. In recent months, the CPI has declined by $1 / 2$ percent year-on-year, while wholesale prices have risen by around 1 percent year-on-year. ${ }^{3}$ Lastly, a large jump in the GDP deflator in the first quarter of 2001 resulted in the decline in this index moderating to $1 \frac{1 / 4}{4}$ percent year-on-year, compared to the $1 \frac{1 / 2}{13 / 4}$ percent declines during 2000 .

\section{In addition to the weak demand environment, a number of other factors may} have contributed to deflation in Japan in recent years. Nagaoka (2000) found that there was a sizable departure from the historic Phillips curve relationship (using the core CPI) during 1998 and 1999. While it is difficult to disentangle the impact of demand and supply shocks on the price level, the Bank of Japan believes that in recent years the impact of deregulation and the streamlining of distribution channels in the retail sector have, in addition to the weak demand environment, contributed to price declines (see Bank of Japan, 2001).

\section{The Labor Market}

15. The impact of the slowing economy is also evident in the labor market. Overtime hours, which had increased quite strongly between early 1999 and mid-2000, particularly in the manufacturing sector, began to decline in late 2000 as firms responded to slowing exports and shipments. Employment, which had actually continued to decline in the first half of 2000 , rose modestly during the second half of the year, but has begun to fall again in recent months, while the ratio of job offers to applicants has also turned down (Figure I.8). In terms of sectoral composition, employment in the construction sector has declined quite sharply over the past two years, that in the services sector has continued the trend increase evident during the 1990s, while in the manufacturing sector, employment levels have stabilized.

16. However, the unemployment rate has yet to be significantly affected. The unemployment rate, which had risen from $3 \frac{1}{2}$ percent to $4 \frac{1}{2}$ percent during the 1998

\footnotetext{
${ }^{2}$ See Bayoumi, 1999, for a detailed discussion on estimating potential growth and the output gap in Japan.

${ }^{3}$ Measurement biases in the CPI are estimated to lead to an overstatement of inflation by around 1 percent (see Shiratsuka,1999).
} 
Figure I.7. Japan: Output Gap and Prices, 1990-2001 1/
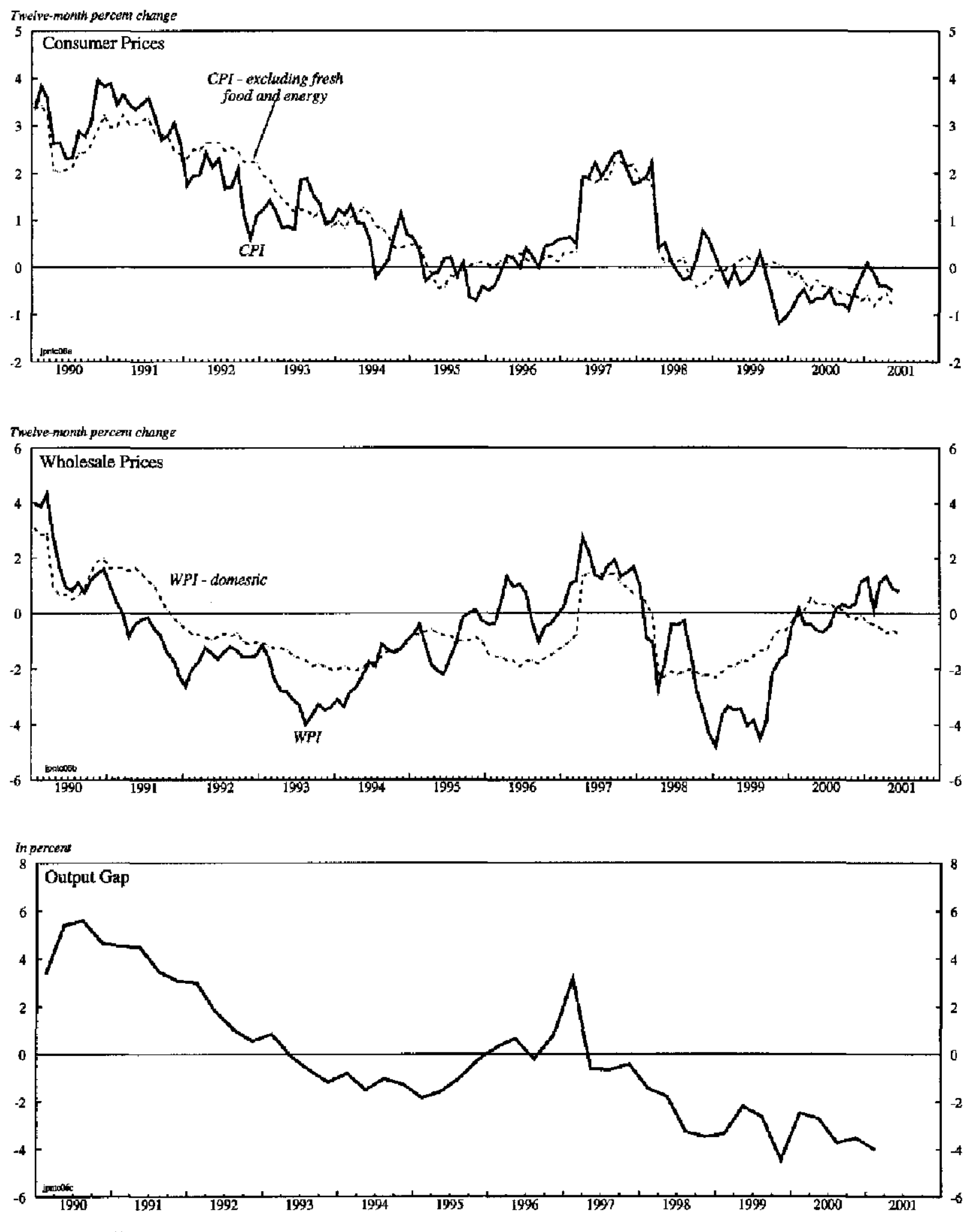

Spurces: Nikkei Telecoom; and WEFA. 
Figure I.8. Japan: Labor Market Conditions, 1990-2001
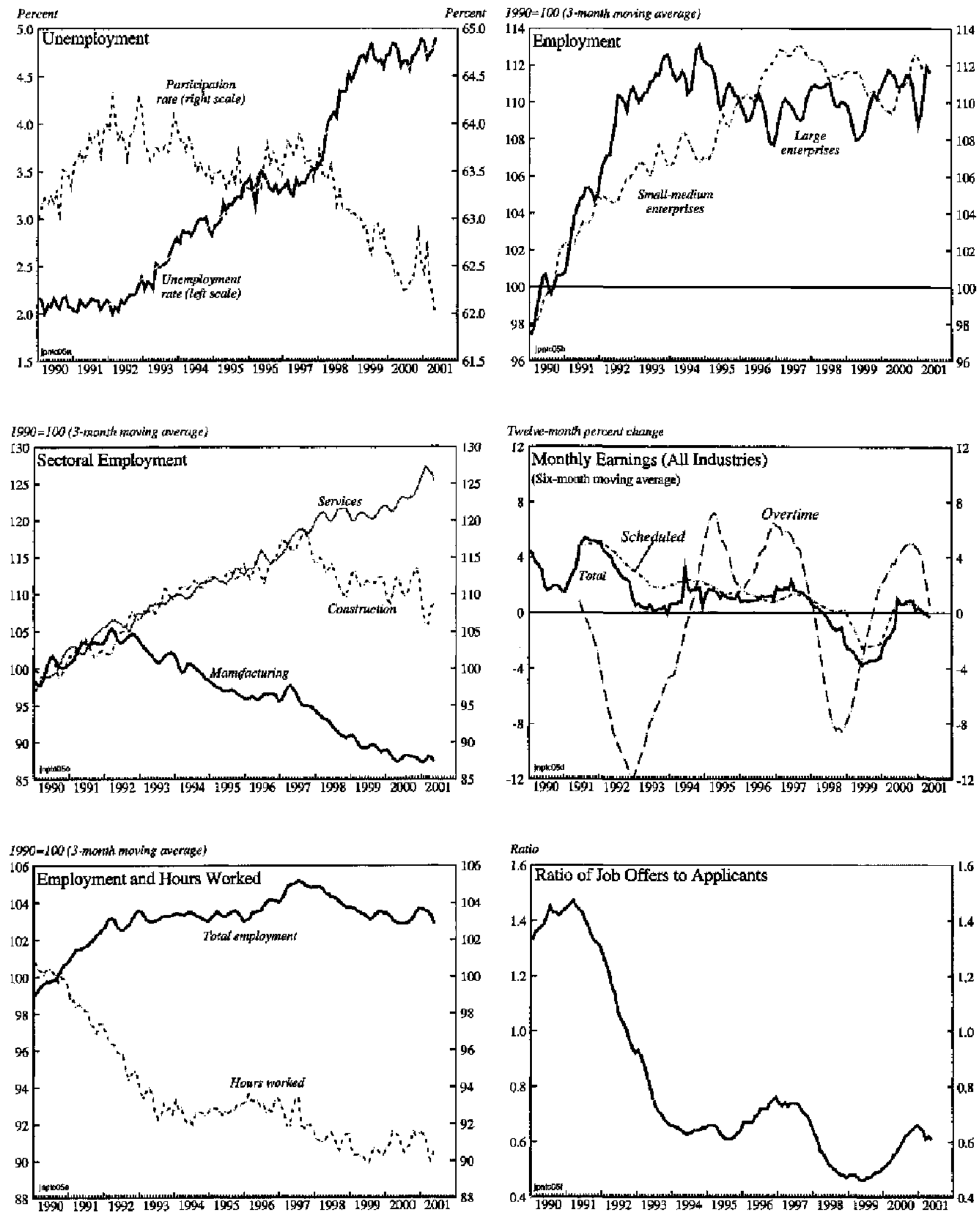

Sources: Nikkei Telecom; and WEFA. 
recession, has risen only modestly further, and has fluctuated around $4 \frac{3}{4}$ percent over the past two years. Official estimates (by the Ministry of Health, Labour, and Welfare) suggest that the structural unemployment rate is around $3 \frac{1}{2}-4$ percent (compared to around 2 percent in the early 1990s), implying that a modest amount of this unemployment is due to cyclical factors. Evidence of an increased structural mismatch in the labor market is also evident in the outward movement of the Beveridge curve since the mid-1990s. ${ }^{4}$ The unemployment and vacancy rates have both risen at the same time suggesting that people who are losing their jobs do not have the skills that new employers are seeking.

\section{A modest recovery in wages has recently faltered. Monthly earnings grew by a} modest $1 / 2$ percent in 2000 (11/2 percent in real terms), after declining by $31 / 4$ percent in 1999 . The recovery in earnings was due to some pick-up in scheduled earnings, an increase in overtime pay as more overtime hours were worked, and a smaller decline in bonus payments (which are tied to past corporate profits) than had occurred in 1999. However, most recently earnings growth has faded as firms have cut back overtime in line with production.

\section{E. External Sector Developments}

\section{Developments in the carrent account over the past two years have been} dominated by the global electronics cycle, increased import penetration in domestic markets, and the rise in international oil prices. Export volumes (customs-clearance basis), which had recovered modestly in 1999 as the impact of the Asia financial crisis waned, grew by $91 / 4$ percent in 2000 as the strong growth in the world economy and the buoyant global electronics market underpinned demand for Japanese products in the first half of the year (Figure 1.9). However, as the positive impact of these factors dissipated in the second half, export volumes declined, and fell by a particularly sharp 31/4 percent in the first quarter of 2001. Import volumes grew strongly-by $91 / 2$ percent in 1999 and 11 percent in 2000 partly due to the recovery of the domestic economy from the 1998 recession, but also because of a considerable rise in import penetration as businesses, particularly in the retail sector, increasingly sourced high-quality, low-cost goods from overseas. Again, however, import growth has more recently eased as the domestic economy bas slowed. After improving in 1999, the terms of trade deteriorated substantially during 2000 as import prices (in dollar terms) rose by $10 \frac{1 / 4}{4}$ percent as a result of the sharp rise in international oil prices. As a result of these developments, the trade surplus narrowed from 3 percent of GDP in 1998 to $2 \frac{1}{2}$ percent of GDP in 2000 , and, to around 2 percent of GDP in the first quarter of 2001 . With the invisibles account in broad balance, the current account surplus also narrowed from 3 percent of GDP in 1998 to $2 \frac{1}{2}$ percent of GDP in 2000, although a strong increase in investment income meant that the current account surplus remained at $2 \frac{1}{2}$ percent of GDP in the first quarter of 2001.

19. Japanese trade with Asia expanded strongly during 2000. Exports to Asia grew by $281 / 2$ percent (U.S. dollar terms) during 2000, while imports from these countries rose by 29 percent (U.S. dollar terms). This compares to the more modest growth in trade with the

\footnotetext{
${ }^{4}$ See Callen and Nagaoka, 2001, in the accompanying Selected Issues volume.
} 
Figure I.9. Japan: External Sector Developments, 1990-2001
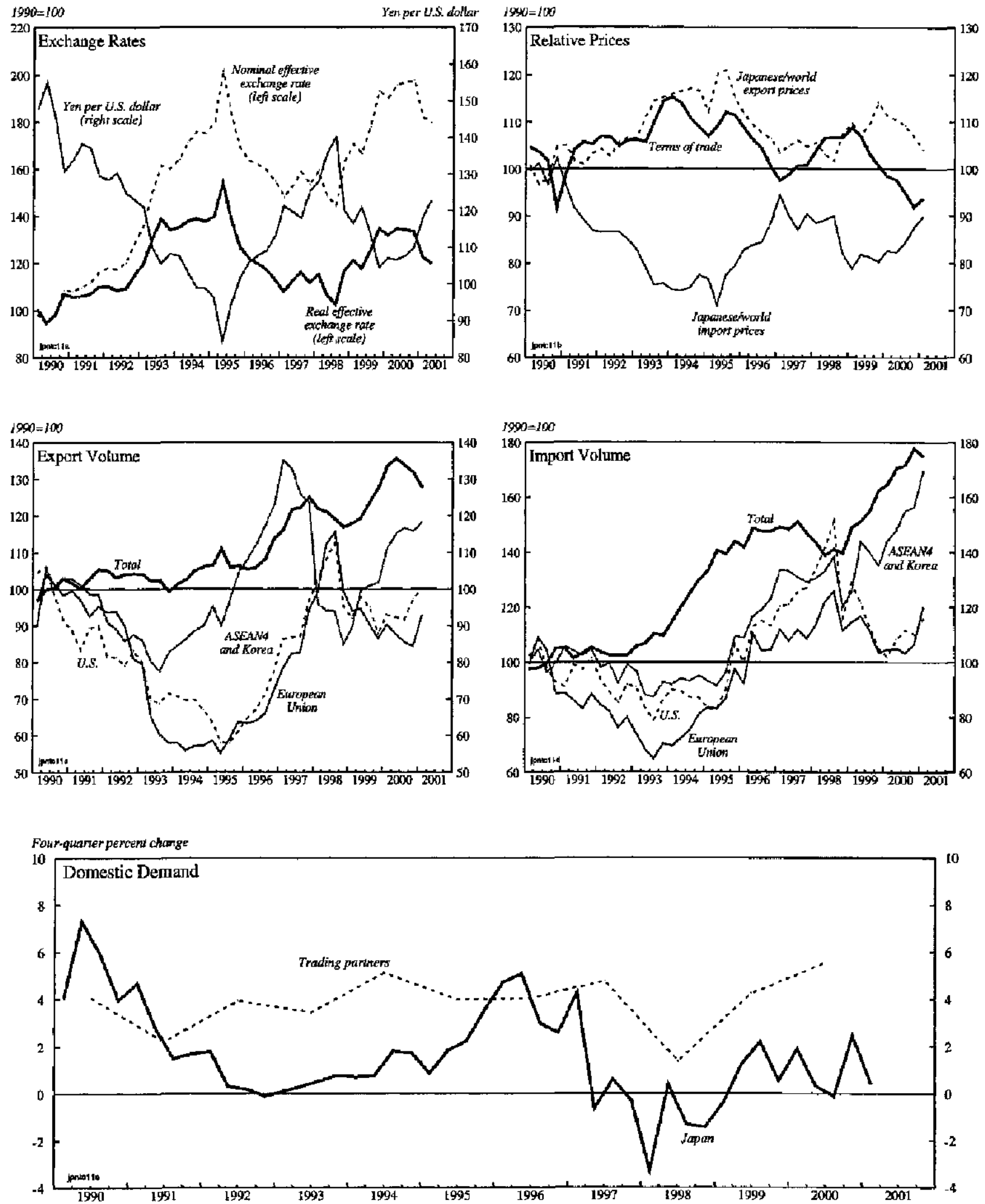

Soufces: Nikkei Telecom; WEFA, Nomura Database; and staff estimates. 
U.S. and Europe. Around 40 percent of Japanese exports currently go to Asia, which is now the largest destination for Japanese exports, with Taiwan POC, Korea, and China being the most important countries in the region. ${ }^{5}$ Some 40 percent of imports are also now sourced from Asian countries. Imports from China, in particular, have shown remarkable growth in recent years, and their share has risen to $14 \frac{1}{2}$ percent of the total.

\section{In the financial account, net FDI and portfolio outflows both increased during} 2000. Net FDI outflows increased to $\$ 23.4$ billion ( $1 / 2$ percent of GDP) in 2000 from only $\$ 10$ billion in 1999 . Japanese FDI abroad increased with new investments concentrated in the U.S. and U.K., while flows to Asia, which have declined substantially in recent years, remained weak. Direct investment in Japan declined slightly to $\$ 8$ billion in 2000 , although this was due to the withdrawals of investment in two large companies as new investments actually reached a record level. While net portfolio outflows increased to $\$ 37$ billion in 2000 , from $\$ 25.6$ billion in 1999 , gross flows declined substantially. On the asset side, Japanese investment abroad was about half of that in 1999 as investments in bonds and money market instruments declined, while foreign portfolio investments in Japan fell from $\$ 143$ billion in 1999 to $\$ 49$ billion in 2000 as a large inflow into equities turned into a small outflow. Reserves increased by close to $\$ 50$ billion in 2000 to stand at $\$ 362$ billion $(9.8$ months of imports of goods and services).

\section{F. Statistical Issues}

\section{The assessment of economic developments in Japan has been complicated by} statistical weaknesses. As documented in last year's Economic and Policy Developments paper, the national accounts statistics bave been very volatile over the past decade. ${ }^{6}$ Concerns about the quality of the national accounts data resulted in the establishment of a working group of statisticians in April 2000 to recommend improvements to the metbodology.

22. In October $\mathbf{2 0 0 0}$, revised national account statisties were published which have addressed a number of the shortcomings in the earlier data. The new statistics, which are only available back to 1980 , were compiled under the System of National Accounts 1993 (SNA93) methodology. The major changes to the expenditure side data are: the inclusion of computer software in capital formation (and the capital stock); the inclusion of consumption of fixed capital of government-owned assets in public consumption; and the transfer of medical expenses insured by the government from private to public consumption. A new seasonal adjustment methodology has also been adopted with the introduction of the X12ARIMA procedure which adjusts for the effects of differences in the number of trading days and the presence of leap-years when calculating seasonal factors, while the "Income and

${ }^{5}$ See Callen and McKibbin, 2001, for a discussion of the trade and financial links between Japan and Asia, and the implications of these links for the transmission of shocks within the region.

${ }^{6}$ See Japan: Economic and Policy Developments, IMF Staff Country Report No. 00/143, November 2000. 
Expenditure Survey for One-Person Households" is now being used in the estimation of private consumption.

23. The new statistics raised the estimated level of nominal GDP by around

$21 / 2$ percent. The inclusion of software investment and public capital depreciation each added about 1 percent to the level of real GDP, while the composition of real GDP has also changed with the share of public consumption rising by around $51 / 2$ percentage points (to 15 percent) and private consumption declining from around 60 percent to 55 percent. In turn, these revisions raised the estimated level of potential GDP, but have done little to change estimates of the output gap.

\section{More recently, a new estimation method for public investment has been} introduced (from the March 2001 quarter) to improve the quality of the data in the preliminary quarterly estimates. Previously, the March quarter data was estimated as the difference between the preliminary fiscal-year figure and the sum of public investment in the preceding three quarters. Under the new methodology, construction statistics as well as preliminary fiscal year data estimated by more accurate fiscal information are used to estimate the March quarter data, with the preceding three quarters' figures being retroactively revised as needed.

\section{Despite the methodological improvements, the volatility of real GDP remains} high. The coefficient of variation of real GDP rose from 0.71 during 1981-1990 to 3.25 during 1991-2000 under the new methodology, (this compares to 3.75 for the period 1991-99 under the old methodology) while for private consumption it rose from 0.8 to 3.83 (Figure I.10). While part of this is attributable to the way policies have been formulated and implemented, technical factors relating to the measurement of the national account statistics have also been responsible. By comparison, the coefficient of variation of real GDP in Germany during $1991-2000$ was 1.75 and in the U.S. 0.58 .

26. Since the beginning of 1999 , growth has been negative in four of the nine quarters despite the fact that the economy expanded in both 1999 and 2000 . However, movements in real GDP have sometimes been at odds with other statistical indicators. For example, as noted above, the sharp drop in private consumption in the fourth quarter of 1999 and the subsequent rebound in the first quarter of 2000 do not appear consistent with other indicators of consumption. The national accounts statistics also give a somewhat confusing picture of developments in the second half of 2000 -showing the economy contracted in the third quarter and then expanded in the fourth quarter-and the overall picture of a moderate decline in activity relative to the first half of the year sits at odds with the continued growth in the all-industries production index. Again in the first quarter of 2001 , real GDP declined while the all-industries production index recorded growth of $1 / 2$ percent, due to strength in the tertiary sector, and the sharp increase in the GDP deflator in the quarter raises the possibility that real expenditures have been underreported.

27. One of the primary weaknesses of the quarterly national accounts data is that the household surveys on which the estimates of private consumption are based are small. The Family Income and Expenditure Survey (FIES) has a sample of 8,000 who are 
Figure I.10. Japan: Growth and Volatility Comparisons

Coefficient of wariation of gaurterly changes in output.

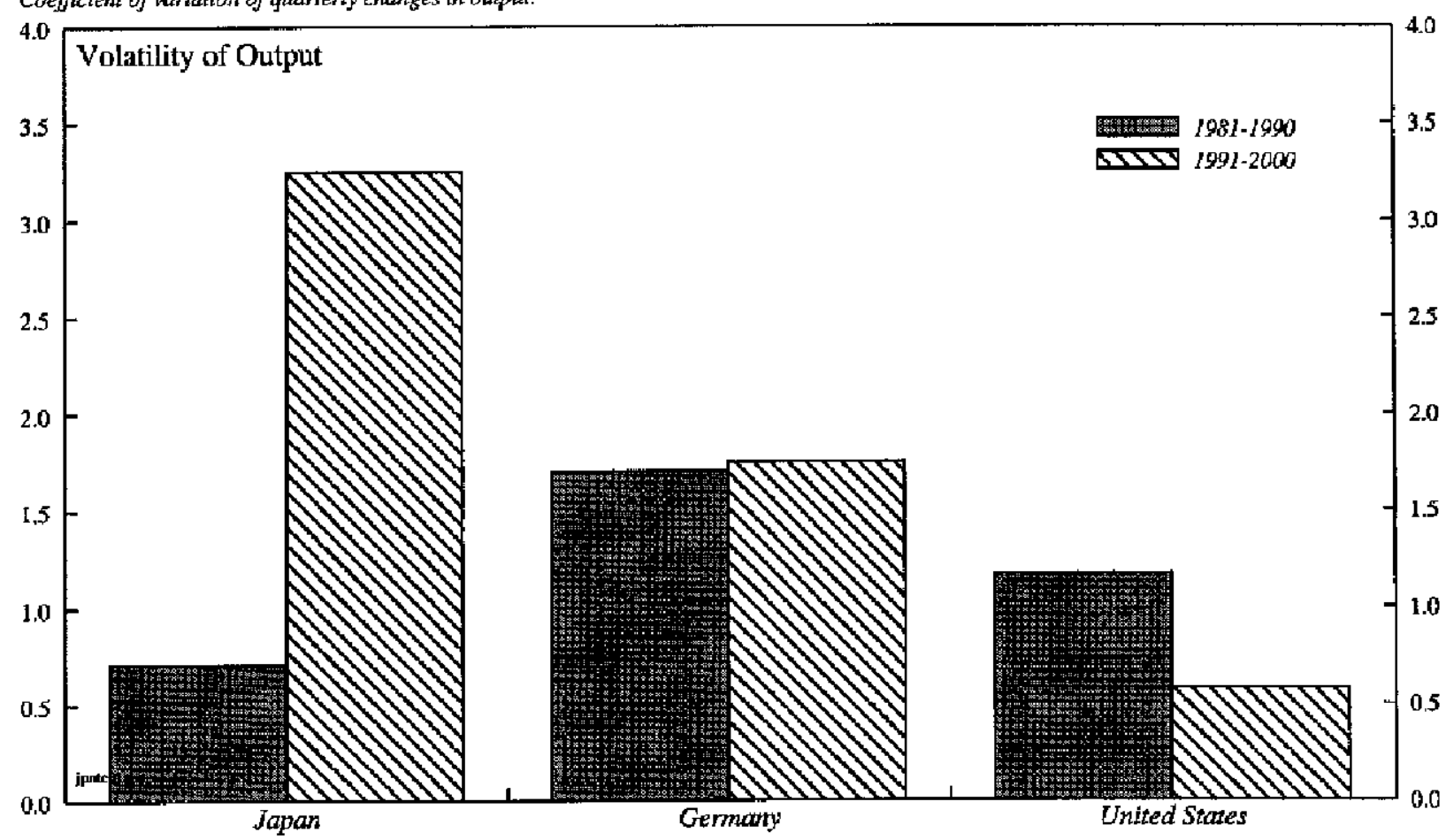

Coefficient of variation of quarieriy changes in output.

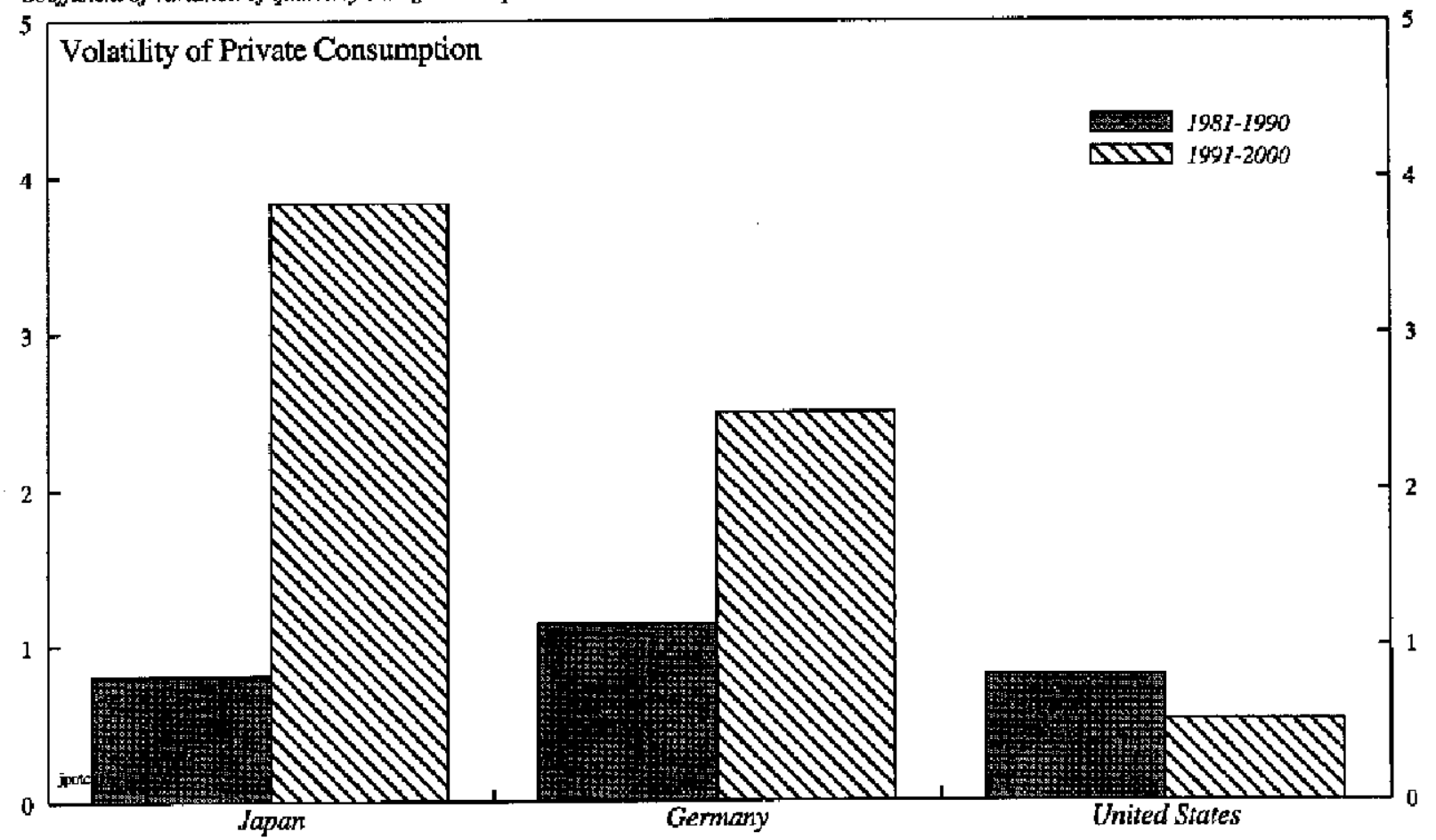

Spurces: IMF, CEl Database; NIkkel Teleøom; and staff calculations. 
surveyed on a rolling six month period (with one-sixth of the survey changing each month). The relatively small size of the sample leads to volatility, particularly in "lumpy" expenditure items such as consumer durables. Meanwhile, the survey of one-person housebolds has a sample of only 750 and is conducted on a rolling three month basis. Again, the small sample size leads to considerable volatility in the data. To improve the quality of the data, a new survey will be introduced in October 2001 which will sample the expenditure of 30,000 households on specific durable consumption goods.

\section{A number of other factors also reduce the usefulness of the national accounts statistics:}

- Timeliness of the data. The national accounts data are generally published two months and ten days after the end of the quarter. The main impediment to the more timely release of the data is the Corporate Survey (published by the Ministry of Finance) which is the main input into the business investment data and is generally released two months and seven days after the end of the quarter.

- Coverage of computer software remains limited. Only “order-made" software is currently included in business investment, while software packages and in-house developed software are not included as capital formation because of a lack of information.

- Investment deflator. There are some doubts about whether the index of computer prices in the WPI (which is also used in the construction of the investment deflator) is adequately capturing the decline in quality-adjusted prices, which may be leading to an understatement of real investment expenditures.

- Lack of quarterly income and production side data. Data limitations mean that only expenditure side statistics and compensation of employees are calculated on a quarterly basis.

\section{References}

Bank of Japan, 2001, "Price Developments in Japan: A Review Focusing on the 1990s," in Bank of Japan Quarterly Bulletin, May 2001.

Bayoumi, T.,1999, "Where Are We Going? The Output Gap and Potential Growth," in T. Bayoumi and C. Collyns (eds) Post-Bubble Blues: How Japan Responded to Asset Price Collapse.

Callen, T., and W. McKibbin, 2001,"Japan and Asia: Policies and Prospects," in the accompanying Selected Issues volume.

Callen, T., and T. Nagaoka, 2001, "Structural Reforms, Information Technology, and Medium-Term Growth Prospects," in the accompanying Selected Issues volume. 
Morsink, J., R. Ramaswamy, M. Mühleisen, and T. Nagaoka, 2000, Japan: Economic and Policy Developments, IMF Staff Country Report No.00/143, November.

Nagaoka, T., 2000, "Japan: The Unemployment Deflation Puzzle," in Japan: Selected Issues, IMF Staff Country Report No. 00/144.

Shiratsuka, S., 1999, "Measurement Errors in Japanese Consumer Price Index," IMES Discussion Paper, Institute for Monetary and Economic Studies, Bank of Japan, No.99-E-23. 


\section{Fiscal Policy Developments ${ }^{1}$}

1. Public finances in Japan are under serious strain. A decade of expansionary fiscal policy has resulted in a high fiscal deficit relative to GDP and a level of government debt that, on some measures, is the highest among the G-7 countries. This situation has generated concerns about the sustainability of fiscal policy. Rising debt service obligations, weak revenues owing to the continued stagnation in economic activity, and rigidities in expenditure management have sharply reduced the room for maneuver in the central and local government budgets. In addition, together with sluggish income growth, adverse demographics have erased much of the earlier surpluses of the social security system, and the situation is projected to deteriorate as population ageing intensifies.

2. The new government has made a commitment to turn the fiscal situation around. Following the large stimulus in FY 1999, the fiscal stance-as measured by the structural balance of the general government - was broadly unchanged in FY2000, and for FY2001, a modest degree of consolidation is expected. ${ }^{2}$ For FY2002, a political commitment has been made to cap net JGB issues to $¥ 30$ trillion, which may significantly increase the withdrawal of fiscal stimulus relative to the current year. The bond issuance target is the first step of a fiscal reform program outlined recently by the Council on Economic and Fiscal Policy (CEFP). The Council's program also states that the goal of fiscal policy over the medium term is to achieve a primary surplus.

3. The Council's reform blueprint outlines a range of other fiscal reforms. The seven-point plan covers issues related to the privatization of public corporations and the postal savings system; a review of public works projects; shoring up the finances of the pension and health care systems; reorganization of relations between the central and local governments to increase the latter's revenue base while increasing accountability; and improvements in budget preparation and spending allocation procedures to enhance expenditure management and fiscal transparency. Taken together, these elements would imply a major overhaul of fiscal management in Japan. However, the details are yet to be fully worked out and a specific timetable for their implementation has not been presented.

4. This chapter is organized as follows. Section A provides a discussion of the budget policies of the central and local governments, and their implications for general government balances. Section B is devoted to the Fiscal Investment and Loan Program (FILP). Section C focuses on recent fiscal reform measures and the remaining agenda. Section $D$ discusses the implications of budget policies for public debt and the adjustment required to stabilize the level of debt over the medium-term.

\section{A. Budget Polieies}

5. The central government's general account budget is considered to be the key lever of control over the fiscal system, although the fiscal stance depends also on the

\footnotetext{
${ }^{1}$ Prepared by Sanjay Kalra (ext. 36142)

${ }^{2}$ The fiscal year starts on April 1.
} 
position of the special accounts and the local governments. ${ }^{3}$ The government's bond issuance is determined by the general account budget which - together with the budgets for 38 special accounts that are controlled by government ministries - is approved by the Diet. The Diet also approves the budgets for government financial institutions and the FILP. It also reviews the Local Government Finance Program (LGFP) which provides a framework for the financing of local governments. The various accounts, agencies, and programs are interlinked. The consolidation of general government operations from these accounts is undertaken as part of the preparation of national income accounts by the Economic and Social Research Institute of the Cabinet Office. To assess the implications of these, and other government operations, the Fund staff uses the broader concept of general government (based on national income accounts-based data) to obtain a comprehensive indicator of the fiscal position. The annual national accounts data are, however, available with a lag of eight months after the end of the fiscal year, thus requiring the staff to estimate the general government's fiscal position for FY2000 on the basis of available quarterly data.

\section{Central government operations}

Fiscal Year 2000

6. The FY2000 initial budget did not contain significant reform measures. In keeping with past practice, the initial general account budget was formulated in relation to the initial budget of the previous year (Table II.I). Central government general expendituretotal general account expenditure excluding debt service payments and local allocation tax transfers-was slated to increase by $2 \frac{1}{2}$ percent, largely on account of higher transfers to the social security special account. The level of public works spending was kept unchanged. Reflecting higher tax revenue projections, and to shore up the weak financial position of the local governments, grants to local governments were increased by around $¥ 1 \frac{1}{2}$ trillion. At the same time, the higher public debt level generated an increase in projected debt service payments of over $¥ 2$ trillion. The budget also included a substantial allocation for the Deposit Insurance Corporation ( $¥ 4 \frac{1}{2}$ trillion) following heavy losses related to bank failures. On the revenue side, the projected increase of $¥ 4$ trillion ( 0.8 percent of GDP) in tax revenues came largely from the interest tax windfall from a high volume of maturing postal savings deposits (Table II.2). The budget provided for net JGB issues of $¥ 32 \frac{1}{2}$ trillion, about $¥ 11 / 2$ trillion more than in the previous year.

\section{A supplementary budget was passed in November 2000 to help sustain economic} recovery. The budget contained expenditure measures of about $¥ 5$ trillion ( 1 percent of GDP), of which half was on public works. The supplementary budget followed the announcement of a stimulus package with a headline figure of $¥ 11$ trillion ( $21 / 4$ percent of GDP). In addition to the real water spending, the package contained additional measures, including to support small and medium-sized enterprises and to stimulate housing investment and employment, mainly through an extension of loan guarantees and increased lending by government financial institutions (Table II.3). This brought the total bond issuance to

\footnotetext{
${ }^{3}$ These concepts, and linkages among them, are discussed in Bayoumi (1998) and IMF (2001).
} 
Table II.1. Japan: Central Government General Account Budget, FY1996-2001

(In bilions of yen)

\begin{tabular}{|c|c|c|c|c|c|c|c|c|c|}
\hline & \multirow[t]{2}{*}{1996} & \multirow{2}{*}{$\frac{1997}{\text { Settlement }}$} & \multirow[t]{2}{*}{1998} & \multicolumn{3}{|c|}{1999} & \multicolumn{2}{|c|}{2000} & \multirow{2}{*}{$\frac{2001}{\text { Injtial }}$} \\
\hline & & & & \multirow{3}{*}{$\begin{array}{l}\text { Initial } \\
81,860\end{array}$} & \multirow{3}{*}{$\begin{array}{l}\text { Revised } \\
89,019\end{array}$} & \multirow{3}{*}{$\frac{\text { Settlement }}{89,037}$} & \multirow{3}{*}{ Initial } & \multirow{3}{*}{$\frac{\text { Revised }}{89,770}$} & \\
\hline Expenditures & 78,848 & 78,470 & 84,392 & & & & & & 82,652 \\
\hline Of which: & & & & & & & & & \\
\hline Social security & 15,032 & 15,385 & 15,658 & 16,095 & 19,112 & 19,022 & 16,767 & 17,761 & 17,555 \\
\hline Public works & 12,340 & 11,067 & 13,034 & 9,931 & 12,235 & 12,972 & 9,434 & 11,494 & 9,435 \\
\hline Defense & 4,815 & 4,950 & 4,956 & 4,932 & 4,915 & 4,897 & 4,936 & 4,934 & 4,955 \\
\hline Official aid & 1,061 & 1,083 & 1,082 & 988 & 998 & 1,019 & 984 & 994 & 956 \\
\hline $\begin{array}{l}\text { National debt service } 1 / \\
\text { Of which: }\end{array}$ & 16,084 & 15,926 & 17,699 & 19,832 & 20,272 & 20,292 & 21,965 & 21,446 & 17,170 \\
\hline Interest payments & 10,725 & 10,600 & 10,796 & 11,368 & 10,907 & 10,444 & 10,743 & 10,225 & 10,402 \\
\hline Transfer of local allocati & & & & & & & & & \\
\hline local government & 13,945 & 15,481 & 14,305 & 13,523 & 12,444 & 13,084 & 14,930 & 15,828 & 16,823 \\
\hline Reventes & 55,442 & 58,751 & 54,083 & 50,810 & 49,444 & 51,472 & 52,377 & 55,172 & 54,334 \\
\hline Taxes and stamp duties & 52,060 & 53,941 & 49,432 & 47,119 & 45,678 & 47,234 & 48,659 & 49,895 & 50,727 \\
\hline Miscellaneous & 3,382 & 4,810 & 4,651 & 3,691 & 3,766 & 4,237 & 3,718 & 5,277 & 3,607 \\
\hline Deficit & 23,406 & 19,719 & 30,309 & 31,050 & 39,575 & 37,566 & 32,610 & 34,598 & 28,318 \\
\hline Financing & 23,406 & 19,719 & 30,309 & 31,050 & 39,575 & 37,566 & 32,610 & 34,598 & 28,318 \\
\hline Bond issues & 21,748 & 18,458 & 34,000 & 31,050 & 38,616 & 37,514 & 32,610 & 34,598 & 28,318 \\
\hline Deficit-financing bonds & 11,041 & 8,518 & 17,000 & 21,710 & 25,500 & $\ldots$ & 23,460 & 23,460 & 19,558 \\
\hline Construction bonds & 10,707 & 9,940 & 17,000 & 9,340 & 13,116 & $\ldots$ & 9,150 & 11,138 & 8,760 \\
\hline \multicolumn{10}{|l|}{ Others } \\
\hline Carried over surplus & 1,658 & 1,261 & $-3,691$ & -- & 959 & 52 & -- & -- & -- \\
\hline Carry in & 4,619 & 2,961 & 1,700 & -- & 5,391 & 5,391 & -- & -- & -- \\
\hline Carry out & $-2,961$ & 1,700 & $-5,391$ & -- & $-4,432$ & 5,339 & -- & -- & -- \\
\hline \multicolumn{10}{|l|}{ Memorandum items: } \\
\hline General expenditure $2 /$ & 48,819 & 47,064 & 52,389 & 46,888 & 56,303 & 55,681 & 48,092 & 52,496 & 48,659 \\
\hline
\end{tabular}

Source: Data provided by the Japanese authorities.

1/ Includes repayments of principal and running costs.

2/ Total expenditure excluding debt service and local allocation tax transfers. 
Table II.2. Japan: Tax Receipts of the Central Government General Account, FY1996-2001

(In billions of yen)

\begin{tabular}{|c|c|c|c|c|c|c|c|c|c|}
\hline & \multirow[t]{2}{*}{1996} & \multirow{2}{*}{$\frac{1997}{\text { Settlement }}$} & \multirow[t]{2}{*}{1998} & \multicolumn{3}{|c|}{1999} & \multicolumn{2}{|c|}{2000} & \multirow{2}{*}{$\frac{2001}{\text { Initial }}$} \\
\hline & & & & Initial & Revised & Settlement & Initial & Revised & \\
\hline & \multicolumn{8}{|c|}{ (In billions of yen, fiscal years) } & \\
\hline Individual income tax & 18,965 & 19,183 & 16,996 & 15,685 & 15,067 & 15,446 & 18,680 & 19,047 & 18,572 \\
\hline Corporate income tax & 14,483 & 13,475 & 11,423 & 10,428 & 9,799 & 10,795 & 9,947 & 10,816 & 11,839 \\
\hline $\begin{array}{l}\text { Taxes on goods and services } \\
\text { Of which: }\end{array}$ & 11,750 & 14,810 & 15,597 & 15,899 & 15,785 & 15,295 & 14,694 & 14,694 & 14,954 \\
\hline Consumption tax & 6,057 & 9,305 & 10,074 & 10,376 & 10,376 & 10,447 & 9,856 & 9,856 & 10,129 \\
\hline Liquor tax & 2,071 & 1,982 & 1,898 & 1,981 & 1,867 & 1,872 & 1,860 & 1,860 & 1,823 \\
\hline Gasoline tax & 1,915 & 1,926 & 1,998 & 2,045 & 2,045 & 2,071 & 2,078 & 2,078 & 2,121 \\
\hline Tobacco tax & 1,080 & 1,018 & 1,046 & 896 & 896 & 905 & 900 & 900 & 881 \\
\hline Custom duties & 1,024 & 953 & 869 & 785 & 785 & 810 & 730 & 730 & 814 \\
\hline Stamp revenue & 1,969 & 1,681 & 1,608 & 1,521 & 1,584 & 1,561 & 1,511 & 1,511 & 1,505 \\
\hline Other & 3,869 & 3,840 & 2,939 & 2,801 & 2,650 & 3,327 & 3,097 & 3,097 & 3,043 \\
\hline \multirow[t]{2}{*}{ Total tax and stamp revenue } & 52,060 & 53,942 & 49,432 & 47,119 & 45,678 & 47,234 & 48,659 & 49,895 & 50,727 \\
\hline & \multicolumn{9}{|c|}{ (Percentage change) $1 /$} \\
\hline Individual income tax & -2.8 & 1.1 & -11.4 & -8.7 & -11.4 & -9.1 & 20.9 & 23.3 & -2.5 \\
\hline Corporate income tax & 5.4 & -7.0 & -15.2 & -11.0 & -14.2 & -5.5 & -7.9 & 0.2 & 9.5 \\
\hline Taxes on goods and services & 3.3 & 26.0 & 5.3 & 0.9 & 1.2 & -1.9 & -3.9 & -3.9 & 1.8 \\
\hline Total tax and stamp revenue & 0.2 & 3.6 & -8.4 & -6.1 & -7.6 & -4.4 & 3.0 & 5.6 & 1.7 \\
\hline
\end{tabular}

Source: Data provided by the Japanese authorities.

1/ Compared to latest available data of the previous year. 
Table II.3. Japan: Summary of Economic Stimulus Packages, 1993-2000

(In trillions of yen)

\begin{tabular}{|c|c|c|c|c|c|c|c|c|}
\hline \multirow[b]{2}{*}{ Date proposed } & \multicolumn{2}{|c|}{1993} & \multirow{2}{*}{$\begin{array}{c}1994 \\
\text { February }\end{array}$} & \multirow{2}{*}{$\begin{array}{c}1995 \\
\text { September }\end{array}$} & \multicolumn{2}{|c|}{1998} & \multirow{2}{*}{$\begin{array}{c}1999 \\
\text { November }\end{array}$} & \multirow{2}{*}{$\begin{array}{c}2000 \\
\text { November }\end{array}$} \\
\hline & April & September & & & April & November & & \\
\hline Total package & 13.2 & 6.2 & 15.3 & 14.2 & 16.7 & 23.9 & 18.1 & 11.0 \\
\hline Tax reductions & 0.2 & - & $5.9 \mathrm{l} /$ & - & $4.6 \quad 1 /$ & $6.0 \mathrm{z}$ & -- & -. \\
\hline Public investment 3 / & 7.6 & 2.0 & 4.5 & 6.5 & 7.7 & 8.1 & 6.8 & 5.2 \\
\hline Land purchases $4 /$ & 1.2 & 0.3 & 2.0 & 3.2 & 1.6 & $\ldots$ & $\ldots$ & $\ldots$ \\
\hline $\begin{array}{l}\text { Increased lending by Housing Loan Corp. } 5 \text { / } \\
\text { Increased lending by government-affiliated }\end{array}$ & 1.8 & 2.9 & 1.2 & 0.5 & -- & 1.2 & 2.0 & $1.17 /$ \\
\hline financial institutions & 2.4 & 1.0 & 1.5 & $2.6 \quad 6 t$ & 2.0 & 6.9 & 7.4 & 4.5 \\
\hline Other & - & - & 0.2 & 2.6 & 0.8 & 1.7 & 1.9 & 0.2 \\
\hline \multicolumn{9}{|l|}{ Memorandtum item: } \\
\hline Total package (in percent of GDP) & 2.7 & 1.3 & 3.1 & 2.9 & 3.2 & 4.6 & 3.5 & 2.1 \\
\hline
\end{tabular}

Source: Data provided by the Japanese authorities; and staff estimates.

1/ Temporary measures.

2/ Later incrcased to $¥ 9.3$ trillion (1.9 percent of GDP).

3/ Public investment comprises general public works (including land purchases), disaster reconstraction, buildings and equipment, and independent public works projects by local government.

4/ Excludes land acquisition for public works projects, which is included in public spending.

5/ Includes loans by the Pension Welfare Service Public Corporation.

6/ Includes $¥ 1.3$ trillion in lending by the Japan Corporation for small business.

$7 /$ Include the expenditures for employment measures. 
$¥ 341 / 2$ trillion for FY2000, about $¥ 3$ trillion less than in FY1999 when the mid-year stimulus package had been substantially larger.

\section{Fiscal Year 2001}

\section{The FY2001 general account budget aimed to underpin growth prospects while} increasing financing for priority programs. General spending by the central government was budgeted to rise by about 1 percent, although overall general account expenditures was reduced by nearly 3 percent, reflecting mainly lower allocations for bank restructuring. The allocation for public works spending was unchanged relative to the FY2000 initial budget. The budget also reflected substantially lower debt service payments ( 1 percent of GDP), including on account of declining average JGB yields. The local government tax allocation grant rose by about $¥ 2$ trillion. The general account deficit was to be financed by a net bond issue of $¥ 28.3$ trillion, raising the outstanding central government bonds to about $¥ 390$ trillion (73 percent of GDP) by the end of FY2001 (Table II.4).

9. The main revenue measures in the budget related to mortgage interest relief, the gift tax, and treatment of corporate mergers and spin-offs. In total, the tax relief offered by the budget was small ( $¥ 190$ billion, less than 0.1 percent of GDP). On mortgage interest, the eligibility time limit for new homebuyers for income tax reimbursement was extended from end-June 2001 to end-December 2003, and the applicable period was shortened from 15 to 10 years. The deduction was also capped at $¥ 5$ million (from $¥ 5.9$ million). On the gift tax, the exemption limit was raised from $¥ 600,000$ to $¥ 1.1$ million. For gifts received for acquiring a home, the exemption limit was raised to $¥ 51 / 2$ million (from $¥ 3$ million). In addition, to facilitate corporate restructuring, the budget included measures to reduce the tax burden in the event of corporate spin-offs and mergers. Specifically, the capital gains tax on assets transferred among corporations as part of the restructuring was deferred until such gains are realized. The tax treatment for shareholders receiving shares in the new entity was similarly revised, and the recognition of capital gains for tax purposes deferred until such gains are realized.

\begin{tabular}{|lcccccc|}
\hline \multicolumn{7}{|c|}{ Table II.4. Japan-Central Government Bond Issues, FY1999-2001 } \\
(In trillions of yen)
\end{tabular}




\section{Achieving the FY2002 target for JGB issues will require substantial budgetary} measures. The MOF's projection for net JGB issues in FY2002 contained in the FY2001 budget documents is $¥ 33.3$ trillion. The government has proposed a reduction in general account spending focused on lower public works spending and transfers to local governments to achieve the $¥ 3.3$ trillion in measures to realize the bond issue target. The CEFP has called for a review and scaling down of public works expenditures, and proposed the elimination of earmarking of gasoline and other tax revenues presently reserved for road construction - $\mathrm{a}$ means to reduce the allocations for public works projects besides improving public expenditure management. Also, the government has proposed that a part of the reduction in the general account deficit for FY2002 be accomplished through a review of transfers to local governments. ${ }^{4}$ The total scale of the measures - under a current services basis-required to achieve the target may be somewhat higher than the 2001 budget documents suggest, given that the MOF projections were made on more optimistic assumptions about growth in FY2001 and stronger prospects for recovery in FY2002. Moreover, there may be additional pressures on the general account to finance spending by special accounts, such as the national pension special account, which have not been accounted for in the MOF projections (Okue, 2001).

\section{Local Government Operations}

11. Fiscal conditions in the local governments have deteriorated. Over the course of the $1990 \mathrm{~s}$, the central government's stimulus programs affected local governments through both the expenditure and revenue channels. On the expenditure side, the local governments bore their share of the large public works component of most stimulus programs, which they financed and implemented either independently or jointly with the central government. On the revenue side, the tax cuts granted by the central government affected local budgets through losses in shared taxes. The depressed state of the local economies further exacerbated these budgetary pressures. The cumulative effect has been to raise the debt service burden substantially. At the same time, the own-revenue collections of the local governments dropped significantly, with corporate tax revenues witnessing an especially sharp decline as enterprises continued to report losses. Reflecting these trends, the total

\footnotetext{
${ }^{4}$ Transfers to local governments are channeled through the Local Allocation Tax and Transfer Special Account (LATTSA). Until FY2000, LATTSA transfers to local governments exceeded those from the general account into the LATTSA which were determined on the basis of revenue sharing arrangements. The difference was financed by borrowings from the Trust Fund Bureau or from commercial banks. Starting in FY2002, however, the LATTSA will no longer have the authority to borrow; instead the general account and the local governments will be jointly responsible for repaying the outstanding debt. As an interim measure in FY2001, the LATTSA will receive $¥ 6$ trillion from the successor of the Trust Fund Bureau (see below), while the general account and the local governments will each contribute $¥ 1.4$ trillion.
} 
outstanding local government debt is estimated to have more than doubled to over 38 percent of GDP at the end of FY2000 (Table II.5).

12. The deteriorating fiscal position of the local governments has prompted substantial consolidation efforts. ${ }^{5}$ The measures adopted have fallen mainly on investment projects financed entirely by the local governments. These cuts have resulted in a substantial decline in the share of public works projects financed and implemented by the local governments. With these cuts, the share of locally financed public works projects fell from around 75 percent in 1991 to around 60 percent in 1999 even as total public works expenditures rose during the 1990s (Table II.6). These cuts were at variance with the LGFPs which aimed at broadly stable investment-to-GDP ratios.

\section{The local governments have supplemented expenditure measures with a search}

for additional revenue sources. Some prefectural governments have made use of the April 2000 decentralization law whereby some specific levies (e.g., on waste disposal, gambling, hazardous goods storage) could be imposed in consultation with the Ministry of General Affairs and without formal approval by the central government. In other cases, prefectures have exploited a loophole in the existing tax legislation which allows local authorities to raise business taxes on a base other than profits (so-called "external" taxes) if a business activity is unique to their jurisdiction. Using these provisions, for example, the Tokyo and Osaka governments have passed legislation to tax the gross profit (as opposed to net income) of major banks conducting business in their prefectures.

\section{General Government Balances}

\section{The budget policies for}

FY2001 imply some reduction in the general government's budget deficit and a withdrawal of fiscal stimulus.

The staff projects that, on a national accounts basis, the general government deficit would fall by about $1 \frac{1 / 4}{4}$ percent of GDP to 61/2 percent (Table II.7). This projection incorporates the November 2000 supplementary budget-which was smaller than in November 1999 and would affect public investment in

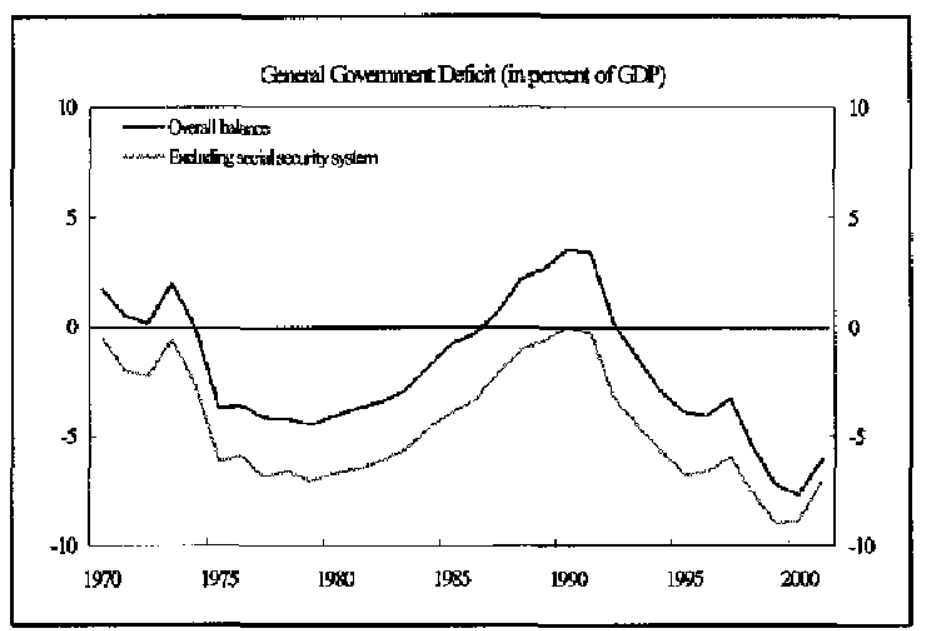

${ }^{5}$ The consolidation measures were encouraged by the statutory limitations on local government borrowing. Two fiscal indicators trigger intervention: (i) a local authority's bond issues are restricted if its ratio of debt service to local tax revenues exceeds 20 percent; and (ii) a prefecture (municipality) is required to undertake fiscal restructuring under direct national (prefectural) control if its fiscal deficit exceeds 5 (20) percent of a standardized expenditure measure. 
Table II.5. Japan: Local Government Operations

(In percent of GDP)

\begin{tabular}{|c|c|c|c|c|c|c|c|c|c|c|}
\hline & 1992 & 1993 & 1994 & 1995 & 1996 & 1997 & 1998 & 1999 & 2000 & 2001 \\
\hline Total revenue (excl. borrowing) If & 15.8 & 15.5 & 15.3 & 15.3 & 15.5 & 15.5 & 15.5 & 15.9 & ++ & $\cdots$ \\
\hline Tax nevenue & 10.6 & 10.3 & 9.8 & 9.9 & 10.1 & 10.3 & 10.2 & 10.1 & +4 & ... \\
\hline Local taxes & 7.2 & 6.9 & 6.6 & 6.7 & 6.8 & 7.0 & 7.0 & 6.8 & $\ldots$ & $\ldots$ \\
\hline Transfers & 3.5 & 3.4 & 3.2 & 3.2 & 3.3 & 3.3 & 3.2 & 3.3 & $m$ & $\cdots$ \\
\hline Other & 5.2 & 5.2 & 5.6 & 5.3 & 5.4 & 5.2 & 5.2 & 5.8 & $\cdots$ & --- \\
\hline Total expenditure & 17.7 & 18.2 & 18.2 & 18.8 & 18.2 & 17.6 & 18.2 & 18.3 & $\ldots$ & -- \\
\hline Mandatory current spending & 6.6 & 6.8 & 7.0 & 7.0 & 7.1 & 72 & 7.4 & 7.4 & $\cdots$ & $\cdots$ \\
\hline of which : Personnel & 5.0 & 5.1 & 5.1 & 5.2 & 5.1 & 52 & 5.3 & 5.3 & $\ldots$ & $\ldots$ \\
\hline Of which : Interest & 0.7 & 0.7 & 0.8 & 0.8 & 0.8 & 0.8 & 0.8 & 0,8 & $\ldots$ & ... \\
\hline Discretionary current spending & 5.1 & 5.0 & 5.1 & 5.4 & 5.2 & 5.0 & 5.2 & 5.7 & $\cdots$ & $\ldots$ \\
\hline Investment & 6.0 & 6.4 & 6.1 & 6.4 & 6.0 & 5.4 & 5.6 & 5.2 & $\ldots$ & -.- \\
\hline Of which : Construction & 5.9 & 6.3 & 6.0 & 6.2 & 5.8 & 53 & 5.5 & 5.1 & $\ldots$ & $\cdots$ \\
\hline Balance & -1.9 & -2.7 & -2.8 & -3.6 & -2.7 & -2.2 & -2.7 & -2.4 & $\ldots$ & $\ldots$ \\
\hline Financing & 1.9 & 2.7 & 2.8 & 3.6 & 2.7 & 22 & 2.7 & 2.4 & $\ldots$ & -.. \\
\hline Borrowing (net) & 2.1 & 3.0 & 2.9 & 3.6 & 2.8 & 2.4 & 2.9 & 1.9 & $\ldots$ & $\ldots$ \\
\hline Borrowing (gross) & 2.9 & 3.9 & 3.8 & 4.5 & 3.8 & 3.6 & 4.1 & 3.4 & $\cdots$ & $\cdots$ \\
\hline Boonds & 2.1 & 2.7 & 2.9 & 3.4 & 3.0 & 2.7 & 2.9 & 2.5 & $\ldots$ & $\cdots$ \\
\hline Other & 0.8 & 1.1 & 0.9 & 1.1 & 0.8 & 0.9 & 1.2 & 0.8 & $\ldots$ & -.. \\
\hline Amortization & -0.8 & -0.8 & -0.9 & -0.9 & -1.0 & -1.1 & -1.3 & -1.5 & $\ldots$ & $\cdots$ \\
\hline Other 21 & -0.2 & -0.3 & -0.1 & -0.1 & -0.1 & -0.3 & -0.1 & 0.5 & $\cdots$ & ... \\
\hline \multicolumn{11}{|l|}{ Memorandum items: } \\
\hline Lucal governutent debt & 16.3 & 18.7 & 21.6 & 24.9 & 27.0 & 28.8 & 31.7 & 33,8 & $\cdots$ & $\ldots$ \\
\hline Of which : Bonds & 12.7 & I 4.4 & 16.3 & 18.5 & 20.0 & 21.4 & 23.3 & 24.3 & $\cdots$ & $\cdots$ \\
\hline Debt service payments & 1.5 & 1.5 & 1.6 & 1.7 & 1.8 & 2.0 & 2.1 & 2.3 & $\cdots$ & $\cdots$ \\
\hline \multicolumn{11}{|l|}{ Loeal Goyernment Finance Plan } \\
\hline Total reventue & 14.3 & 14.4 & 14.3 & 14.2 & 14.0 & 14.4 & 14.8 & 15.0 & 15.2 & 15.3 \\
\hline Local tax & 7.0 & 7.1 & 6.6 & 6.7 & 6.5 & 7.1 & 7.5 & 6.9 & 6.9 & 7.0 \\
\hline Local allocation tax & 3.2 & 3.2 & 3.1 & 3.2 & 33 & 3.3 & 3.4 & 4.1 & 4.2 & 4.0 \\
\hline Local transferred tax & 0.4 & 0.4 & 0.4 & 0.4 & 0.4 & 0.2 & 0.1 & 0.1 & 0,1 & 0.1 \\
\hline Treasury disbursement & 2.5 & 2.5 & 2.9 & 2.6 & 2.5 & 2.6 & 2.5 & 2.6 & 2.6 & 2,6 \\
\hline Rents and fees & 0.3 & 0.3 & 0.3 & 0.3 & 0.3 & 0.3 & 0.3 & 0.3 & 0.3 & 0.3 \\
\hline Other & 0.9 & 1.0 & 1.0 & 1.0 & 1.0 & 1.0 & 1.0 & 1.1 & 1.2 & 1.2 \\
\hline Total expenditure & 15.4 & 15.7 & 16.4 & 16.5 & 16.5 & 16.7 & 16.9 & 17.2 & 17.4 & 17.6 \\
\hline Debt service & 1.3 & 1.3 & 1.8 & 1.5 & 1.7 & 1.9 & 2.0 & 2.2 & 2.4 & 2.5 \\
\hline Wugus and salaries & 4.3 & 4.5 & 4.5 & 4.5 & 4,4 & 4.5 & 4.6 & 4.6 & 4.6 & 4.7 \\
\hline General administration & 3.1 & 3.3 & 3.3 & 3.4 & 3.4 & 3.5 & 3.6 & 3.7 & 3.9 & 4.1 \\
\hline Evestment & 5.1 & 5.5 & 5.9 & 6.1 & 6.0 & 6.0 & 5.7 & 5.7 & 5.6 & 5.4 \\
\hline Special independen: works & 0,2 & 0,3 & 0,3 & 0,3 & 0.5 & 0.4 & 0.4 & 0.4 & 0.4 & 0.4 \\
\hline Other & 1.4 & 0.8 & 0.6 & 0.6 & 0.5 & 0.5 & 0.6 & 0.5 & 0.6 & 0.6 \\
\hline Deficit (=Bond issue) & -1.1 & -1.3 & -2.1 & -2.3 & -2.5 & -2.3 & -2.1 & -2.2 & -22 & -2.3 \\
\hline
\end{tabular}

Source: Ministry of Home Affairs; Ministry of Finance; and staff calculations.

$1 /$ Using data provided by the authorities, the staff has reelassified fimancing items which are treated as revennes in the official statistics.

2/ Including classification errors and omissions. 
Table I.6. Japan: General Government Public Works Projects

(In billions of yen)

\begin{tabular}{|c|c|c|c|c|c|c|c|c|c|}
\hline & 1991 & 1992 & 1993 & 1994 & 1995 & 1996 & 1997 & 1998 & 1999 \\
\hline Solo projects & 18,432 & 21,491 & 25,651 & 24,505 & 23,488 & 22,953 & 20,845 & 21,544 & 19,873 \\
\hline Central goverrment 1 / & 3,759 & 4,427 & 7,777 & 7,459 & 6,383 & 6,216 & 5,393 & 6,895 & 6,984 \\
\hline Local government & 14,674 & $17,6) 65$ & 17,874 & 17,046 & 17,104 & 16,738 & 15,452 & 14,650 & 12,889 \\
\hline Joint projects $2 /$ & 8,802 & 10,244 & 11,493 & 11,184 & 12,547 & 11,915 & 11,061 & 11,945 & 11,650 \\
\hline \multicolumn{10}{|l|}{ Financed by: } \\
\hline Central government & 3,662 & 5,245 & 5,907 & 5,748 & 6,412 & 6,124 & 5,674 & 6,140 & 5,988 \\
\hline Lncal government & 5,140 & 4,999 & 5,586 & 5,435 & 6,136 & 5,791 & 5,387 & 5,805 & 5,662 \\
\hline $\begin{array}{l}\text { Financial contribution of local } \\
\text { governments to central projects }\end{array}$ & 1,039 & 1,260 & 1,340 & 1,088 & 1,462 & 1,254 & 1,236 & 1,693 & 1,573 \\
\hline Total public works & 28,273 & 32,995 & 38,483 & 36,776 & 37,496 & 36,123 & 33,142 & 35,182 & 33,096 \\
\hline \multicolumn{10}{|l|}{ Implemented by: } \\
\hline Central government & 4,798 & 5,687 & 9,117 & 8,547 & 7,845 & 7,470 & 6,629 & 8,588 & 8,557 \\
\hline Local goverrment & 23,476 & 27,308 & 29,367 & 28,229 & 29,652 & 28,653 & 26,513 & 26,594 & 24,539 \\
\hline \multicolumn{10}{|l|}{ Financed by: } \\
\hline Central goverument & 7,421 & 9,671 & 13,6984 & 13,2080 & 12795 & 12,340 & $1.1,067$ & 13,034 & 12,972 \\
\hline Local goverment & 20,853 & 23,324 & 24,799 & 23,569 & 24,701 & $23,7 \dot{B} 2$ & 22,075 & 22,148 & 20,124 \\
\hline \multicolumn{10}{|l|}{ Memordndum iterts } \\
\hline \multicolumn{10}{|l|}{ Central government share in } \\
\hline joint projects & 41.6 & 51.2 & 51.4 & 51.4 & 51.1 & 51.4 & 51.3 & 51.4 & 51.4 \\
\hline $\begin{array}{l}\text { Share of public works finaticed b } \\
\text { central government }\end{array}$ & 26.2 & 29.3 & 35.6 & 35.9 & 34.1 & 34.2 & 33.4 & 37.0 & 39.2 \\
\hline \multicolumn{10}{|c|}{ Share of public works implemented by } \\
\hline local government & 83.0 & 82.8 & 76.3 & 76.8 & 79.1 & 79.3 & 80.0 & 75.6 & 74.1 \\
\hline \multicolumn{10}{|c|}{ Total public works (percent of GDP) } \\
\hline & 6.0 & 6.8 & 7.9 & 7.5 & 7.5 & 7.0 & 6.4 & 6.8 & 6.4 \\
\hline
\end{tabular}

Source: Ministry of Finance; Local Government White Paper, various issues; and staff calculations.

$1 /$ Calculated as total central government expenditure on public works mimus central share of joint public works.

$2 /$ Joint projects are implemented by local govermments. 
the following fiscal year--and continued constraints at the local level. The projection assumes that local governments will continue to cut back on locally financed public works projects and that a small ( $* 1$ trillion) supplementary budget will be passed in the autumn. The structural deficit (including social security, but excluding bank support)-which reflects more closely the impact on aggregate demand--is projected to decrease by a little over $1 / 2$ percentage point of GDP.

15. Further fiscal consolidation is likely in FY2002. The overall impact of the reduced expenditures-through lower public works allocation and transfers to local governments in the general account budget-required to meet the $¥ 30$ trillion JGB issue target is somewhat difficult to assess since the composition of the expenditure cuts is yet to be firmed up. Also, it is difficult to foretell the likely impact of the cuts in general account transfers on local governments' expenditure plans. Moreover, the initial point in the projections is subject to some margin of error given the lack of consolidated data for FY2000. Subject to these uncertainties, the staff's current estimate is that the impact of these measures would be to reduce the structural general government deficit by about 1 percent of GDP in FY2002.

\begin{tabular}{|c|c|c|c|c|c|}
\hline \multicolumn{6}{|c|}{$\begin{array}{c}\text { Table II.7. Japan—General Government Operations, 1998-2002 } \\
\text { (In percent of GDP) }\end{array}$} \\
\hline & FY1998 & FY1999 & $\begin{array}{c}\text { Est. } \\
\text { FY2000 }\end{array}$ & $\begin{array}{l}\text { Proj. } \\
\text { FY2001 }\end{array}$ & $\begin{array}{l}\text { Proj. } \\
\text { FY2002 }\end{array}$ \\
\hline General government balance & -5.4 & -7.1 & $-7,6$ & -6.7 & -5.9 \\
\hline Excluding social security & -7.3 & -8.9 & -8.6 & -7.4 & -6.3 \\
\hline Taxes and fines & 17.3 & 16.8 & 17.2 & 17.2 & 17.0 \\
\hline Consumption & 9.2 & 9.4 & 9.8 & 9.6 & 9.3 \\
\hline Investment & 5.8 & 5.6 & 5.2 & 4.9 & 4.1 \\
\hline Support for banks & 0.2 & 0.7 & 0.8 & -- & -- \\
\hline Social security balance & 1.9 & 1.7 & 1.0 & 0.7 & 0.5 \\
\hline $\begin{array}{l}\text { Change in structural balance } \\
\text { (including social security, } \\
\text { excluding bank support) }\end{array}$ & -1.1 & -1.3 & -0.2 & 0.6 & 0.9 \\
\hline Source: Staff estimates. & & & & & \\
\hline
\end{tabular}

\section{FIL.P Operations}

\section{B. Fiscal Investment and Loan Program}

\section{As a tool for fiscal management, the FILP plays an important role in Japan. By} financing government activities and extending loans to government financial institutions (GFIs) and public enterprises, it has helped to build Japan's infrastructure and, more recently, provided fiscal stimulus to sustain the pace of economic activity. Although the FILP is not formally a part of the general government sector, its annual plan is formulated in coordination with the budget process, and is submitted to the Diet together with the regular government budget. Indeed, owing to its size, the FILP is often referred to as the "second budget". During the expansionary phase of fiscal policy, substantial additional FLP loans were announced as part of the 1998 and 1999 stimulus packages, mainly to improve credit conditions in the economy and extend financial support to local governments. However, the decline in the flow of funds into the postal savings and pension systems in FY1999, largely 
in response to weak income growth, prompted a sharp reduction in investments in government bonds.

17. During FY2000, the withdrawal of funds from the postal savings systemrelated to the maturation of postal savings deposits - further constrained the room for FILP investment. In the course of the

fiscal year, the postal savings system registered a fall in deposits of about $¥ 91 / 2$ trillion, compared to the Postal Savings Bureau's initially projected outflow of $¥ 16$ trillion yen. ${ }^{6}$ Excluding withholding taxes on interest and amounts above the $¥ 10$ million deposit limit, the postal savings system recorded a redeposit rate of about 72 percent on more than $¥ 50$ trillion in maturing deposits. However, the surpluses of the pension system have

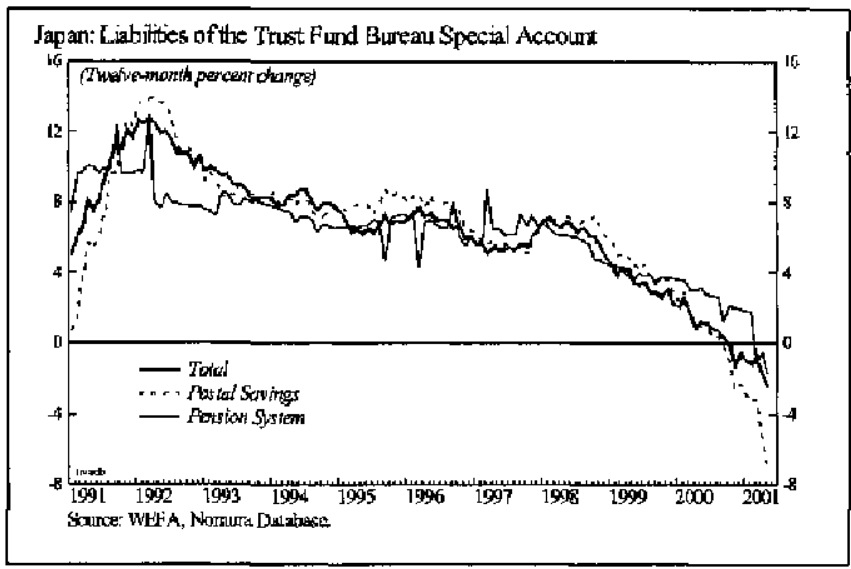
also been declining as income growth has been sluggish, payment morale has been low, and payouts continue to mount. In response, amounts allocated for portfolio investments were again reduced sharply (Table II.8).

\section{In FY2001, continued reduction in inflows required broader cuts in FILP} spending, as the general FILP budget was trimmed substantially, reflecting reductions in housing loan programs, support for SMEs, and programs of the other government financial and non-financial institutions. By contrast, financing for the local governments was increased by a small amount.

\section{FILP Reform}

19. A comprehensive reform of the FILP was initiated in April 2001. The aim of the reform program is to progressively align the activities of the program with market principles. The key elements of the reform bill approved by the Diet were the following:

- Increasing role of market financing. Until FY2000 the primary source for FILP funds was Japanese savings held by public institutions, including the postal savings and public pension systems, which were invested by the Ministry of Finance's Trust Fund

\footnotetext{
${ }^{6}$ The postal savings system holds roughly $¥ 250$ trillion ( 50 percent of GDP) in deposits, largely in 10-year fixed-term savings instruments (teigaku), which have been fully invested in the FILP. About 40 percent of these funds were deposited between April 1990 and March 1992, when teigaku interest rates were at their peak, and are now about to mature. The Postal Savings Bureau had estimated that about $¥ 50$ trillion in funds would flow out of the postal savings system by March 2002.
} 
Table II.8. Japan: Fiscal Investment and Loan Program (FILP), FY1996-2001

(In trillions of yen)

\begin{tabular}{|c|c|c|c|c|c|c|c|c|}
\hline & \multirow[t]{2}{*}{1996} & \multirow{2}{*}{$\frac{1997}{\text { Actual }}$} & \multirow[t]{2}{*}{1998} & \multicolumn{2}{|c|}{1999} & \multicolumn{2}{|c|}{2000} & \multirow{2}{*}{$\frac{2001}{\text { Initial } 3 /}$} \\
\hline & & & & Revised & Actual & Initial & Revised & \\
\hline Sources of funds & 50,877 & 57,200 & 65,620 & 54,313 & 45,826 & 43,676 & 44,285 & $\cdots$ \\
\hline Trust Fund Bureau & 39,706 & 47,272 & $55,82 \mathrm{I}$ & 44,800 & 36,490 & 33,305 & 33,862 & $\ldots$ \\
\hline Postal savings & 11,522 & 15,597 & 12,222 & $\ldots$ & 4,140 & - & $\ldots$ & $\ldots$ \\
\hline Welfare and national pensions & 7,319 & 7,697 & 5,667 & $\ldots$ & 4,547 & 2,720 & $\ldots$ & $\ldots$ \\
\hline Repayment and other & 20,865 & 23,978 & 37,932 & $\ldots$ & 27,803 & 30,585 & $\ldots$ & $\ldots$ \\
\hline Industrial investment special account & 58 & 55 & 447 & 214 & 202 & 110 & 110 & $\ldots$ \\
\hline Postal life insurance fund & 8,133 & 7,016 & 6,753 & 6,580 & 6,416 & 6,380 & 6,380 & $\ldots$ \\
\hline \multicolumn{9}{|l|}{ Government-guaranteed bonds and } \\
\hline Borrowing & 2,981 & 2,858 & 2,599 & 2,719 & 2,719 & 3,881 & 3,933 & $\cdots$ \\
\hline Uses of funds & 50,877 & 51,440 & 65,352 & 54,313 & 45,826 & 43,676 & 44,285 & 32,547 \\
\hline Purchase of government bonds & 4,976 & 4,800 & 11,000 & -- & -. & -- & $=$ & -. \\
\hline FILP & 45,901 & 46,640 & 54,352 & 54,313 & 45,826 & 43,676 & 44,285 & 32,547 \\
\hline Portfolio investzments 1 & 8,591 & 12,030 & 17,300 & 13,550 & 11,750 & 6,210 & 6,210 & -- \\
\hline General FLLP & 37,310 & 34,610 & 37,052 & 40,763 & 34,076 & 37,466 & 38,075 & 32,547 \\
\hline \multicolumn{9}{|l|}{ Central government projects } \\
\hline (special accounts) & 828 & 745 & 625 & 388 & 365 & 363 & 369 & 291 \\
\hline Govemment nonfinancial enterprises & 8,374 & 8,022 & 6,717 & 6,808 & 6,175 & 6,383 & 6,404 & 5,285 \\
\hline Government financial agencies & 18,878 & 17,115 & 19,384 & 24,572 & 18,754 & 22,845 & 22,884 & 18,957 \\
\hline \multicolumn{9}{|l|}{ Of which: } \\
\hline Housing Finance Corporation & 10,121 & 6,372 & 6,238 & 10,118 & 7,589 & 10,387 & 10,387 & 8,363 \\
\hline Local governments & 8,891 & 8,433 & 10,025 & 8,740 & 8,526 & 7,650 & 8,180 & 7,820 \\
\hline Other & 339 & 294 & 302 & 255 & 255 & 225 & 238 & 194 \\
\hline \multicolumn{9}{|l|}{ Memorandum items: } \\
\hline \multicolumn{9}{|l|}{ Increase in General FILP } \\
\hline (in percent) 2 & 9.0 & -7.2 & 7.1 & -5.4 & -8.0 & -8.1 & -6.6 & -13.1 \\
\hline General FILP as a percent of GDP $2 /$ & 7,2 & 6.7 & 7.2 & 7.9 & 6.6 & 7.3 & 7.4 & 6.3 \\
\hline
\end{tabular}

Source: Ministry of Finance.

1/ Reflects the funding of the "lend-back" system under which the postal savings system, public pension funds, and the postal life insurance fund receive funds for portfolio management on their own account.

2/ Compared to latest available data of the previous year.

$3 /$ As part of the FILP reform, effective April 1, 2001, the Trust Fund Bureau Special Account was replaced by the Fiscal Loan Fund Special Account.

(CInternational Monetary Fund. Not for Redistribution 
Bureau (TFB). Starting FY2001, the compulsory transfer of deposits from the postal savings and pension systems to the TFB was abolished. Henceforth, the government will need to raise funds by issuing additional bonds (zaito bonds) and financing bills, to be transferred to a newly created Fiscal Loan Fund Special Account (FLFSA). ${ }^{7}$

- FILP-agency bonds. Individual FILP agencies are encouraged to issue their own bonds. While the government may guarantee such bond issues in limited circumstances, the bulk of agency bonds is expected to be issued without guarantees. In FY2001, twenty FILP agencies-including the Housing Loan Corporation, the Japan Highway Corporation, the Finance Corporation for Municipal Enterprises, the Development Bank of Japan, the Japan Bank for International Cooperation, and the Shoko Chukin Bank - are slated to tap the markets directly for financing, with the total bond issuance expected to amount to $¥ 1.1$ trillion (around $3 / 2$ percent of the general FILP spending). These agencies have sought bond ratings and the initial market response appears to have been favorable, which may reflect the general perception that these bonds implicitly carry government guarantees and that the agencies willing to enter the market may be the most financially sound among the FILP agencies.

- Cost analysis. To assess their prospective financial implications and to improve their efficiency, subsidy cost analyses of FILP agencies and projects will be undertaken. These analyses are intended to assess the long-term viability of agency activities, including by identifying future government subsidies required to maintain financial balance.

\section{Fiscal Reforms}

\section{Social Security Reforms}

20. Japan's unfavorable demographic trends are also adding to fiscal pressures. Under current projections, Japan is likely to experience the most rapid increase among the G-7 countries in the share of the elderly in its total population, and, by 2020 , the number of senior citizens is projected to be around 33 million (about 25 percent of the population). These trends imply sharply increasing pressures on health care and pension costs. ${ }^{8}$

\section{A far-reaching bill for the reform of the public pension system was approved by} the Diet in March 2000. The bill included cuts in lifetime pension benefits by around

\footnotetext{
${ }^{7}$ For an interim time period of seven years (the maturity of the outstanding loans to the FILP), the postal savings and pension systems would continue to underwrite FLP bonds, but at successively lower levels. In FY2001, the postal savings system is slated to subscribe to $¥ 17.9$ trillion out of a total issuance of $¥ 43.9$ trillion in zaito bonds; the remainder would be absorbed by the pension reserves ( $¥ 11.9$ trillion), the postal life insurance ( $¥ 3.6$ trillion), and the bond market ( $¥ 10.5$ trillion).
}

${ }^{8}$ See H. Faruqee and M. Mühleisen (2001). 
20 percent for future retirees and an increase in the eligibility age for earnings-related pensions, considered sufficient to limit future increases in pension contribution rates in both the (basic) National Pension and (earnings-related) Employee Pension Insurance (EPI) schemes by a substantial margin. The Ministry of Labor, Health and Welfare estimated that, absent the reform, the required contribution rate to maintain the solvency of the EPI would have to rise to $34 \frac{1}{2}$ percent of monthly wages by 2025 (compared to the current level of 17.35 percent). Following the reforms, the required rate to ensure solvency is estimated at 25 percent in 2025. Of course, such estimates are subject to a wide margin of error; future contribution increases could be higher, for example, if the fertility rate does not recover as projected.

\section{Despite the reform measures, the finances of the pension system remain under} strain. Although the reforms are estimated to have reduced the projected net liabilities of the pension system by almost 30 percent of GDP to around 60 percent of GDP, these liabilities are still relatively large by industrial country standards. Moreover, this estimate is also based on the assumption that the amount of government transfers to the basic pension scheme would be raised, effective 2004 , from one third to one half of the basic pension benefits.

\section{The reform blueprint of the CEFP addresses the continued difficult finances of} the public pension system. Once again, while the details are yet to be worked out, the blueprint states as one of the government's goals the creation of a reliable and easily understood social insurance system. It proposes the introduction of individual social security account to help people track their payments and benefits. The blueprint also calls for a review of pension taxation to smooth the tax burden among generations.

\section{Some progress has been made in health care reform, but key reforms are still under consideration:}

- A revised Health Insurance Law was enacted in December 2000. A key provision of the law was that patients aged 70 and above would pay a fixed proportion (10 percent) of their medical costs, replacing the flat rate system. The provision would help shore up the finances of health insurance societies that are running out of legally mandated reserves due to growing payments for medical care for the elderly. However, some of the relief may come from senior citizens abstaining from doctor visits. An amended Medical Service Law which eased advertising restrictions on medical institutions and enhanced the nurse-inpatient ratio was also passed.

- However, further significant reform of the system is still required. Last year's revisions will likely be insufficient to curb growing medical costs while maintaining a safe and high-quality medical system. Issues that need to be addressed include implementation of stricter examination of cost breakdowns on medical bills, resolution of the gap between official drug prices covered by insurance and the prices paid by hospitals, and improved information disclosure and the quality of services offered at hospitals and clinics. An extensive reform of the system is planned for FY2002.

- A government panel is considering proposals which could form the basis of the reform of the national health insurance program. The panel's stated goal is to restrict 
the growth of medical costs for the elderly (currently rising at an average rate of 4 percent a year) to no more than GDP growth. The panel's proposals include provisions for senior citizens with sufficient assets and income to shoulder a greater share of costs; a revamping of the current system of reimbursing hospitals for medical costs and paying artificially high government-mandated prices for drugs; and reductions in public nursing care and health insurance coverage for high-income seniors.

\section{Public works}

25. Longstanding concerns about public works have become acute in recent years. Public criticism has been directed at the economic value of the projects-both at the central and local level-as well as at the contracting procedures. In a number of cases, project revenue has been substantially lower than projected, mostly on account of over-optimistic assumptions of the size of the economy. Costs have also frequently been higher than anticipated, including on account of restrictions placed on the number of bidders and bidding practices which favor well-connected local construction companies.

\section{To address the efficiency issues, new guidelines for a review of public works} projects were announced in early July. These guidelines apply to projects which are incomplete after ten years of being approved. The guidelines are more forward-looking than the current provisions and allow for scrapping of projects whose prospects for completion are uncertain. In addition, projects which have not begun five years after approval, will be reviewed. These steps follow action taken in the fall of 2000 when, after a review of projects by the ministries and a panel of the ruling coalition, 233 projects worth $¥ 2.8$ trillion ( $/ 2$ percent of GDP) were recommended for cancellation.

27. Contracting procedures have also been reformed. The government has started disclosing data on tenders and contracts for public works projects costing more than $¥ 2 \frac{1}{2}$ million. This cost limit is expected to cover more than 95 percent of all public works projects. The ministries and local authorities are also required to release their job performance evaluations of public works contractors. In the past, ministries and local governments have scored the performance of contractors after completion of a job, and the results were sent to the contractors but not made public. Moreover, the government is also considering proposals to exclude financially weak companies from bidding for public work contracts unless the bid would be covered by a bank guarantee. Starting October 2001 , the government will accept bids online for public works projects and will make available via the Internet bidding results and information on plans to invite tenders for directly controlled public works projects. Electronic bidding will expand gradually in FY2002 and FY2003 and is expected to be used for all projects starting FY2004.

28. The CEFP blueprint suggests a need for further review of public works projects and related budget procedures. It emphasizes the need to reform the current practice of earmarking revenues for particular public works projects (e.g., road construction), to review 
existing budget allocation procedures which distinguish between public work and non-public work projects, to make allocations across regions more flexible, and to review long-term public works plans.

\section{Tax Reform}

\section{The Tax Commission Report suggested wide-ranging reform measures for the} tax system. As part of an extensive review of the tax system in FY2000, it recommended tax policy measures to improve government finances as well as steps that could be taken to improve tax administration. These recommendations included a review of the income tax exemptions and deductions; the introduction of consolidated corporate taxation; a larger role for the consumption tax in government revenues; rationalization of the inheritance tax structure; reorganization of central and local tax responsibilities; and the introduction of taxpayer identification numbers.

30. The government has begun to contemplate these recommendations. To broaden the income tax base, a reduction in personal income tax exemptions is being considered. The discussion on consolidated corporate taxation has also progressed. Issues related to the reorganization of taxation responsibilities between the national and local governments are expected to be a key element of the FY2002 budget discussions.

\section{Fiscal Transparency}

\section{The recent Fund staff's Report on the Observance of Standards and Codes} identified areas for improving fiscal transparency in Japan. The report noted that while the Japanese fiscal system is complicated, the budget process meets a high standard of transparency, including a solid legal basis and clear administrative accountability, public availability of comprehensive budget documentation, and regular reporting on budget execution. Moreover, recent initiatives - the enactment of freedom of information legislation, steps towards administrative reform of the national government, opening up of the deliberations of policy councils for greater public input, the publication of a balance sheet, ${ }^{9}$ and the FILP reforms-have improved fiscal transparency. The key areas identified for further progress were:

- Providing timely information on the overall stance of fiscal policy. This would require providing more comprehensive measures of the fiscal position, with a focus on the finances of the general government, regular reporting on fiscal developments, including the provision of a detailed mid-year budget report, and less reliance on supplementary budgets, in particular by formulating initial budgets to reflect the desired stance of fiscal policy.

\footnotetext{
${ }^{9}$ The balance sheet was published in October 2000 . It reported assets and liabilities as of end-FY1998 and covered the general and special accounts, including the social security system. The reported net liabilities were in the range of $¥ 130-770$ trillion, depending on the treatment of pension reserves and the present value of future government transfers and pension contributions.
} 
- Examination of fiscal policy in a longer-term context. This would require the development of a medium-term budget framework which would allow the annual budget to be formulated in a forward-looking manner, and projections of social security and health spending which are integrated with budget projections as a basis for assessing long-term fiscal sustainability.

- Clarification of the role of public financial intermediation. This would require a review and restatement of the objectives of the FILP and provision of more information on its financial implications, and on that of the financial implications of any public policy obligations that are retained by other government ministries and agencies.

\section{Medium-term Fiscal Sustainability}

32. Japan's fiscal deficit and gross debt are now the highest among major industrial countries. The fiscal position has worsened especially during the latter half of the $1990 \mathrm{~s}$, in part on account of the weak state of the economy. However, even after adjusting for the weak cyclical position of the economy, the fiscal deficit has been higher than other $G-7$ countries, and is in marked contrast to the earlier decades when conservative fiscal policies generated low deficits and debt levels.

\begin{tabular}{|lcccccccc|}
\hline \multicolumn{7}{|c|}{ Table II,9. General Government Finances, 2000 } \\
(In percent of GDP) \\
\hline Canada & France & Germany & Italy & U.K. & U.S. & Japan \\
Actual balance & $5.3^{1}$ & $-1.5^{1}$ & $1.3^{1}$ & $3.6^{1}$ & 5.9 & $0.1^{1}$ & $-9.2^{1}$ \\
Structural balance & 3.3 & -0.9 & -0.5 & -0.7 & 3.4 & 1.0 & $-6.8^{1}$ \\
Gross debt & 101.6 & 58.3 & 60.2 & 110.2 & 41.3 & 57.3 & 130.2 \\
\hline Source: IMF World Economic Outlook, April 2000; staff estimates. & & & & \\
'Excluding social security.
\end{tabular}

33. A number of conceptual issues arise in assessing the size of Japan's public debt burden. ${ }^{10}$ The gross concept is likely to overstate the level of govemment debt as the government holds substantial assets, primarily through the pension system. Netting out these assets also poses problems as the assets of the pension system are more than offset by its projected future liabilities, and the value of assets may be overstated by the book value of claims. Furthermore, compared to other countries, the government's involvement in financial intermediation is substantial. A large portion of the loans extended by GFIs is to public corporations for social infrastructure projects, which exposes the government to future losses. In addition, the government has also guaranteed market debt issued by these corporations and other public agencies. The illiquid nature of the FILP assets, the troubled finances of the public corporations, and the substantial volume of government-guaranteed debt have

${ }^{10}$ For a discussion, see OECD, Gross and Net Debt Measures in Japan, 1998. 
generated concerns about the contingent liabilities attached to these loans and guarantees. These considerations need to be borne in mind when assessing the actual and potential public debt obligations in Japan.

34. By whatever measure chosen, Japan's public debt has risen sharply since the early 1990 s. By end-2000, general government gross debt had reached 130 percent of GDP. However, the sizeable assets of the government have kept net debt (around 45 percent of GDP at end-1999) at a relatively low level by international standards. The assets of the pension system (valued at 55 percent of GDP) and financial assets held by the central and local governments ( 45 percent of

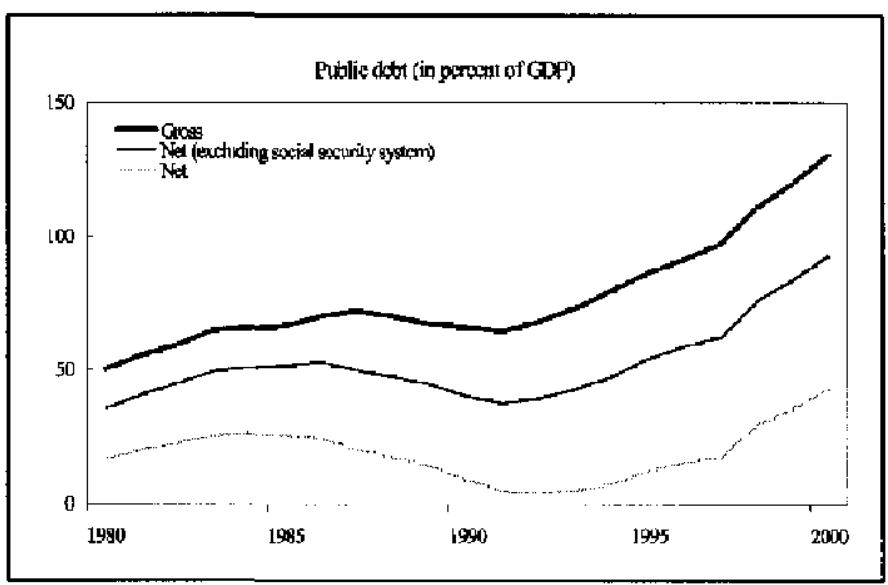
GDP) account for the difference between gross and net debt. An alternative definition of net debt would treat the social security system as independent and exclude its assets-which for Japan are more than offset by the projected net future liabilities of the pension system - from public debt calculations. This concept of net debt excluding the social security system is used by the staff to assess Japan's fiscal position. At nearly $951 / 2$ percent of GDP at the end of FY2000, net debt excluding the social security system was higher than in most other industrialized countries.

\section{The general government's true net obligations may be somewhat higher than} suggested by the net debt figures. Specifically, it is difficult to estimate the true value of government assets, in part because some of them are illiquid. It is also possible that the government may need to bear some contingent liabilities arising from its loan programs. While the default rate on loans by government financial institutions has so far been low (bad loans account for about 1-2 percent of the total loan portfolio), many large public infrastructure investments appear to generate significantly less than bucgeted returns, which may imply an inability to meet debt service obligations, and thus significant liabilities for the government (as happened in the case of the Japanese National Railway Settlement Corporation). For example, a recent study of the finances of the Japan Highway Corporation and the Honshu-Shikoku Bridge Authority by the Ministry of Land, Infrastructure, and Transport suggests that revenue shortfalls for these public corporations would lead to a large increase in their outstanding debt. ${ }^{11}$ In the event that these corporations are unable to service their debts, the government would need to step in to meet repayment obligations which could be substantial. The total amount of outstanding government-guaranteed debts amounted to

\footnotetext{
${ }^{11}$ The study states, for example, that a 10 percent lower-than-projected traffic on the national expressways could increase the debt of the Highway Corporation-currently at $¥ 23$ trillionto $¥ 31$ trillion over a 50 year period.
} 
$¥ 55 \% / 4$ trillion (about 10 percent of GDP) at end-2000. The government may also be called on to cover losses related to $¥ 411 / 2$ trillion in guarantees extended by regional credit guarantee associations to cover bank loans to small and medium-sized enterprises (including $¥ 20$ trillion in outstanding special loan guarantees that have been extended since 1998).

\section{In part reflecting concerns about the mounting public debt burden, rating} agencies have downgraded Japan's sovereign rating over the past year. Citing rising debt levels and the government's diminished fiscal flexibility, Standard and Poor's downgraded Japan's long-term local and foreign currency sovereign credit ratings from AAA to AAt in February 2001. In March 2001, Fitch downgraded the outlook for Japan from "stable" to "negative" citing concerns over "the political uncertainty that have seen the structural reform agenda effectively grind to a halt since the last rating action in June 2000." Earlier, in September 2000, Moody's had downgraded the yen-denominated domestic securities issued or guaranteed by the government to Aa2 from Aal, while maintaining a negative outlook.

\section{Stabilizing public debt}

37. To place public debt on a sustainable path, substantial fiscal adjustment will be required over the medium term. The extent of consolidation that may have to be undertaken to stabilize public debt can be derived from the accounting relationship between debt and budget deficits, the primary balance necessary to stabilize the debt-to-GDP ratio in the year $t:$

$$
b_{t}^{p}=\left(r_{t}-g_{t}\right) /\left(1+g_{t}\right) d_{t}
$$

where $b^{p}$ is the target for the primary balance in percent of GDP, $d$ is the debt-to-GDP ratio, and $r$ and $g$ are the values for the nominal interest rate paid on government debt and the nominal GDP growth rate, respectively. The amount of fiscal consolidation necessary to stabilize the debt-to-GDP ratio (the "required adjustment") can then be calculated as the difference between the value of $b^{p}$ and the current cyclically adjusted primary balance of the general government (excluding social security), estimated at $-3 \frac{1}{2}$ percent of GDP in FY2001.

\section{Net debt and primary balance for the general government excluding social} security, are used as proxies for $d$ and $b^{p}$, respectively. As regards $r$, an implicit measure can be derived from the interest paid on government debt which reflects past debt contracted at different maturities and interest rates. As interest rates on government bonds have generally been declining in recent years, the current value of $r$ is higher (at roughly $3 \frac{1}{4}$ percent) than the current yield on 10 -year JGBs ( $11 / 4$ percent). With an average debt maturity of about 4-5 years, the projected future changes in JGB yields affect the average interest rate only gradually.

\section{The staff's current baseline forecast corresponds to a scenario in which real} growth converges to a medium term potential of about 2 percent, and real JGB yields rise 
to $2 \frac{1}{2}$ percent by $2005 .^{12}$ In this case, fiscal adjustment of $3 \frac{3 / 4}{4}$ percent of GDP-sufficient to generate a structural primary balance by FY 2006 - would stabilize net debt (excluding social security assets) around 110 percent of GDP, compared to an estimated 100 percent of GDP in 2001 (Table II.10). The required fiscal adjustment would be smaller, however, were the potential growth rate to increase, and correspondingly higher if the growth rate were to fall. Variations in JGB yields also change the required fiscal adjustment. For example, if real interest rates fell to around 1 percent, the required adjustment would be $1 / 2$ percent of GDP smaller than in the baseline scenario. A more gradual consolidation effort to stabilize net debt by 2010 scenario would require approximately the same cumulative shift in the structural balance, but spread out over a longer period. However, slower adjustment under this scenario would lead to higher debt accumulation in the interim and stabilization of debt at a higher level of about 120 percent of GDP.

\begin{tabular}{|c|c|c|c|c|c|c|}
\hline \multicolumn{7}{|c|}{ Table II.10. Japan: Baseline Scenario for Medium-Term Debt Consolidation } \\
\hline $\begin{array}{l}\text { General Government } \\
\text { excluding } \\
\text { social security }\end{array}$ & FY2001 & FY2002 & FY2003 & FY2004 & FY2005 & FY2006 \\
\hline & \multicolumn{6}{|c|}{ (In trillions of yen) } \\
\hline Balance & -37.5 & -33.3 & -29.7 & -26.2 & -22.6 & -18.7 \\
\hline Primary & -21.6 & -17.5 & -13.3 & -8.9 & -4.3 & 0.6 \\
\hline Net interest payments & -15.9 & -15.8 & -16.4 & -17.3 & -18.3 & -19.3 \\
\hline Debt & 511.3 & 544.6 & 574.3 & 600.4 & 623.1 & 641.8 \\
\hline \multicolumn{7}{|c|}{ (In percent of GDP } \\
\hline Balance & $-7,4$ & -6.4 & -5.6 & -4.8 & -4.0 & -3.2 \\
\hline Primary & -4.2 & -3.4 & -2.5 & -1.6 & -0.8 & 0.1 \\
\hline Net interest payments & -3.1 & -3.0 & -3.1 & -3.2 & -3.3 & -3.3 \\
\hline Structural balance & -6.8 & -6.1 & -5.4 & -4.7 & -3.9 & -3.2 \\
\hline Structural Primary balance & -3.6 & -3.0 & -2.3 & -1.5 & -0.8 & 0.1 \\
\hline Net debt (excluding social security) & 100.3 & 104.9 & 108.3 & 110.3 & 111.1 & 1111 \\
\hline \multicolumn{7}{|c|}{ (In percent) } \\
\hline \multicolumn{7}{|l|}{ Memorastdum items: } \\
\hline Implied interest rate & 3.2 & 3.1 & 3.0 & 3.0 & 3,0 & 3.1 \\
\hline JGGB yield & 1.2 & 1.8 & 2.4 & 2.9 & 3.5 & 3.5 \\
\hline In real terms & 2.0 & 0.8 & 1.4 & 1.9 & 2.5 & 2.5 \\
\hline Nominal GDP growth & -0.4 & 1,8 & 2.2 & 2.6 & 3.0 & 3.0 \\
\hline Real growth & 0.4 & 0.8 & 1.2 & 1.6 & 2.0 & 2.0 \\
\hline Deflator & -0.8 & 1.0 & 1.0 & 1.0 & 1.0 & 1.0 \\
\hline Nominal GDP ( $¥$ trillion) & 509.7 & 519.0 & 530.4 & 544.3 & 560.8 & 577.7 \\
\hline
\end{tabular}

\footnotetext{
${ }^{12}$ Inflation is assumed to be flat at 1 percent a year throughout. For simplicity, it is assumed that growth and interest rates on new debt converge in a linear fashion to their steady-state values by 2005 , and the adjustment in the structural balance is also assumed to be linear over the adjustment period. Variations in the paths of interest rates and growth towards their endpoints have only small effects on the required adjustment.
} 


\section{References}

Bayoumi (1998), The Japanese Fiscal System and Fiscal Transparency, in Aghevli, et. al. (eds.), Structural Change in Japan: Macroeconomic Impact and Policy Challenges, IMF.

Faruqee, H. and M. Mühleisen (2001), "Population Aging in Japan: Demographic Shock and Fiscal Sustainability" MMF Working Paper 01/40, Washington, DC.

IMF (2001), Japan: Report on the Observance of Standards and Codes, Fiscal Transparency Module.

Okue, K. (2001), Japan's Fiscal Status and Outlook: Rising Systemic Risk, Dresdner Kleinwort Wasserstein, Tokyo. 


\section{MONETARY Developments ${ }^{1}$}

1. Faced with a weakening economy, the Bank of Japan (BOJ) in March 2001 returned to an ultra-low interest environment in the context of a new policy framework that targets the level of current account balances (bank and nonbank deposits) held at the BOJ. The new framework - which is to remain in place until year-on-year changes in consumer prices rise stably to zero or above-includes the possibility that the BOJ might engage in quantitative easing by raising the current account target and step up purchases of government bonds, if needed, to meet the target. Since implementing the new framework, interest rates have declined along the yield curve, but overall monetary conditions are not substantially different from levels in the first half of 2000 , when the economy was considerably stronger. The BOJ has not used the flexibility under the new framework so far, partly because of concerns that a higher target might be difficult to achieve, and partly because of the uncertain nature of the monetary transmission mechanism at zero interest rates.

\section{A. Policy Developments}

2. Having abandoned its zero-interest rate policy (ZIRP) in August 2000, the Bank of Japan (BOJ) began to change its view of the economy later in the year. Through most of the second half of 2000 , the BOJ's assessed that a gradual economic recovery-driven by increasing corporate profits and strong business investment-was underway, which would eventually lead to a narrowing of the supply-cemand gap and a subsequent pickup in inflation. This view - which underpinned the assessment that deflationary concerns had been dispelled and thus paved the way for the lifting of the ZIRP-was increasingly inconsistent with the deterioration in economic indicators, and persistent price declines which cast doubt about whether the output gap was narrowing. ${ }^{2}$ The BOJ revised its economic assessment in mid-December 2000 when it acknowledged that the pace of the recovery was slowing, owing to decelerating export growth. By that time, renewed concerns over the health of the banking system had also emerged, following the release of weak interim results for FY2000 and the precipitous decline in the stock market that eroded banks' latent capital gains.

\section{The BOJ's first response to the worsening outlook was to address liquidity} concerns in the financial system. According to the minutes for the January 19 meeting, several Policy Board members suggested that a preemptive interest rate cut to ward off further economic slowdown and ease financial sector concems would be appropriate under normal circumstances. Under almost zero rates, however, Board members felt that the impact of a small reduction in the overnight rate would be negligible and thus decided to leave rates

\footnotetext{
${ }^{1}$ Prepared by Martin Mühleisen (ext. 38686).

${ }^{2}$ The BOJ interpreted the decline in nominal price indices as a side-effect of significant structural change in the economy ("good" deflation), ratber than a lack of aggregate demand (see On Price Stability, a BOJ report published in October 2000).
} 
unchanged. Instead, BOJ staff were asked to explore ways by which sufficient liquidity could be provided to the markets, particularly towards the close of the financial year in March. This led to the introduction of a Lombard-type facility at the following Policy Board meeting.

\section{Under the new "Complementary Lending Facility", announced on February 9,} the BOJ stands ready to provide potentially large funds to financial institutions on demand (against collateral), as opposed to the injection of liquidity on auction dates chosen by the BOJ. ${ }^{3}$ Borrowers are charged the BOJ's "basic loan rate" (or discount rate), which was reduced by 15 basis points to 0.35 percent on the same date. While the move eased concems about the availability of overnight liquidity, the impact on monetary conditions was likely small. At that time, the discount facility was no longer in use, and loans under the new facility are only available for a total of 5 working days out of every reserve maintenance period (currently one month). ${ }^{4}$ Loans taken out in excess of 5 days are charged an additional premium of 200 basis points.

5. In a second step, the BOJ decided to lower the target for the overnight call rate by 10 basis points to 0.15 percent on February 28 . This decision was mostly triggered by economic considerations, particularly the news that industrial production had deteriorated in January.

\section{Finally, the BOJ announced a shift to a quantitative operating target for} monetary policy on March 19, a move that caused short-term interest rates to fall again to their floor. The policy has three main components:

- While overnight rates are to be market-determined in the future, the BOJ now targets current account balances held by its counterparts at around $¥ 5$ trillion-about the same as during the ZIRP period and some $¥ 1$ trillion above the average balance held in the months prior to the introduction of the new policy (see below). As a result, the overnight call rate-now determined on the basis of supply and demand - has remained close to zero for most of the period since the policy has been in place.

- The policy is to remain in place until annual CPI inflation (excluding perishables) has reached zero or above on a sustained basis. This distinguishes the new policy framework from the earlier zero-interest rate policy, which only sought to maintain zero interest rates until deflationary concerns were dispelled-a much vaguer notion.

- The BOJ is also prepared to step up outright purchases of long-term government bonds (rinban operations) if necessary to meet its liquidity target, which is a

${ }^{3}$ The new facility became operative on March 16, 2001 .

${ }^{4}$ To streamline its money market operations, the BOJ has since abolished the discounting of commercial bills, the Import Bills Refinancing Facility, and the Lending Facility at a Nonbasic Loan Rate. The main remaining function of the basic loan rate will thus be to reduce interest rate volatility by putting an effective ceiling on the ovemight call rate. 
significant departure from its earlier policy of purchasing a fixed amount of government bonds in secondary markets each month. The amount of JGBs owned by the BOJ is not to exceed the sum of outstanding banknotes, which is estimated to allow the BOJ to purchase an additional $¥ 10-15$ trillion in JGBs if needed.

\section{The new policy framework, while similar to the original ZIRP, is stronger} because of its explicit commitment to maintain the current stance until deflation has been eliminated, and because of the built-in flexibility to raise the current account target if necessary. However, the new policy does not constitute a shift towards the adoption of an inflation target, mainly because the BOJ has not committed itself to eradicate deflation within a particular timeframe. In its Oetober 2000 report on price stability, the BOJ expressed concern that monetary policy instruments may no longer be effective in a deflationary phase characterized by zero nominal interest rates and balance sheet adjustments. In such circumstances, the BOJ could have only limited impact on the price level. Indeed, growth and inflation forecasts by members of the BOJ's Policy Board - which have been published on a semi-annual basis since October 2000 -indicate that the Board on average expects a continuation of the deflationary environment in FY2001. Moreover, as revealed in the minutes of recent Board meetings, some Board members have been concerned about the difficultly of achieving a higher policy target, as financial institutions' demand for additional funds might be insufficient. Consistent with these views, the Board has so far refrained from making use of the additional flexibility provided under the new policy framework.

\section{B. Interest Rates and Monetary Stance}

\section{Recent policy actions have} reinforced a general decline of interest rates along the yield curve. Yields on short to medium-term securities fell immediately after the adoption of the new policy framework, and have since remained around record lows as the BOJ stepped up purchases of short-term government bills to achieve its liquidity target (see below).

Bond markets have also been bullish as financial institutions have continued to shift

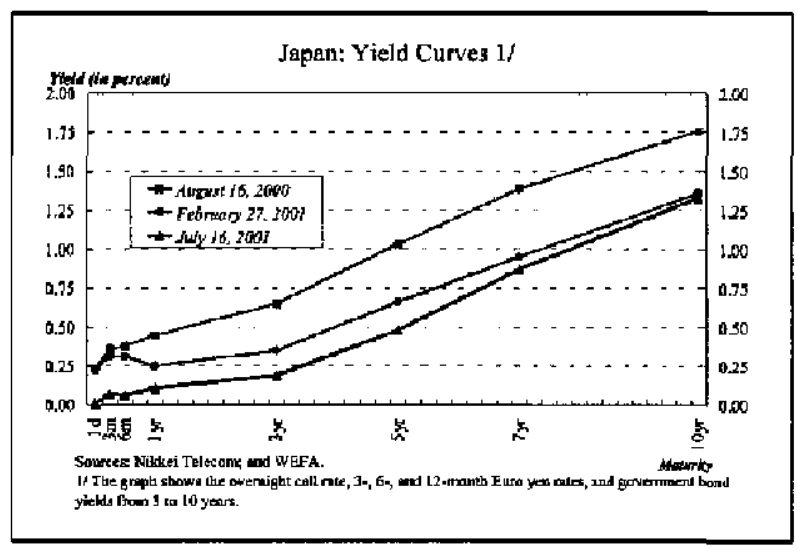
funds into JGBs, and the weakening economic outlook has added to downward pressures on yields. The government's move to concentrate medium-term issues on the 5-year maturity has led to a sharp yield decline in that segment, with record lows below 0.4 percent reached in June. The 10-year JGB yield also dropped to its lowest level in almost three years after the BOJ's policy measures in March, and has remained broadly around 1.15 percent since (Figure III.1). Bank deposit and lending rates have also fallen back to record lows reached last summer. Rates were already reduced after the February rate cut, and banks have now reduced interest rates on regular savings deposits from 0.1 percent to 0.02 percent, while the short-term prime rate has declined from 1.5 percent to around 1.375 percent. 
Figure III.1. Japan: Selected Interest Rates, 1995-2001 1/
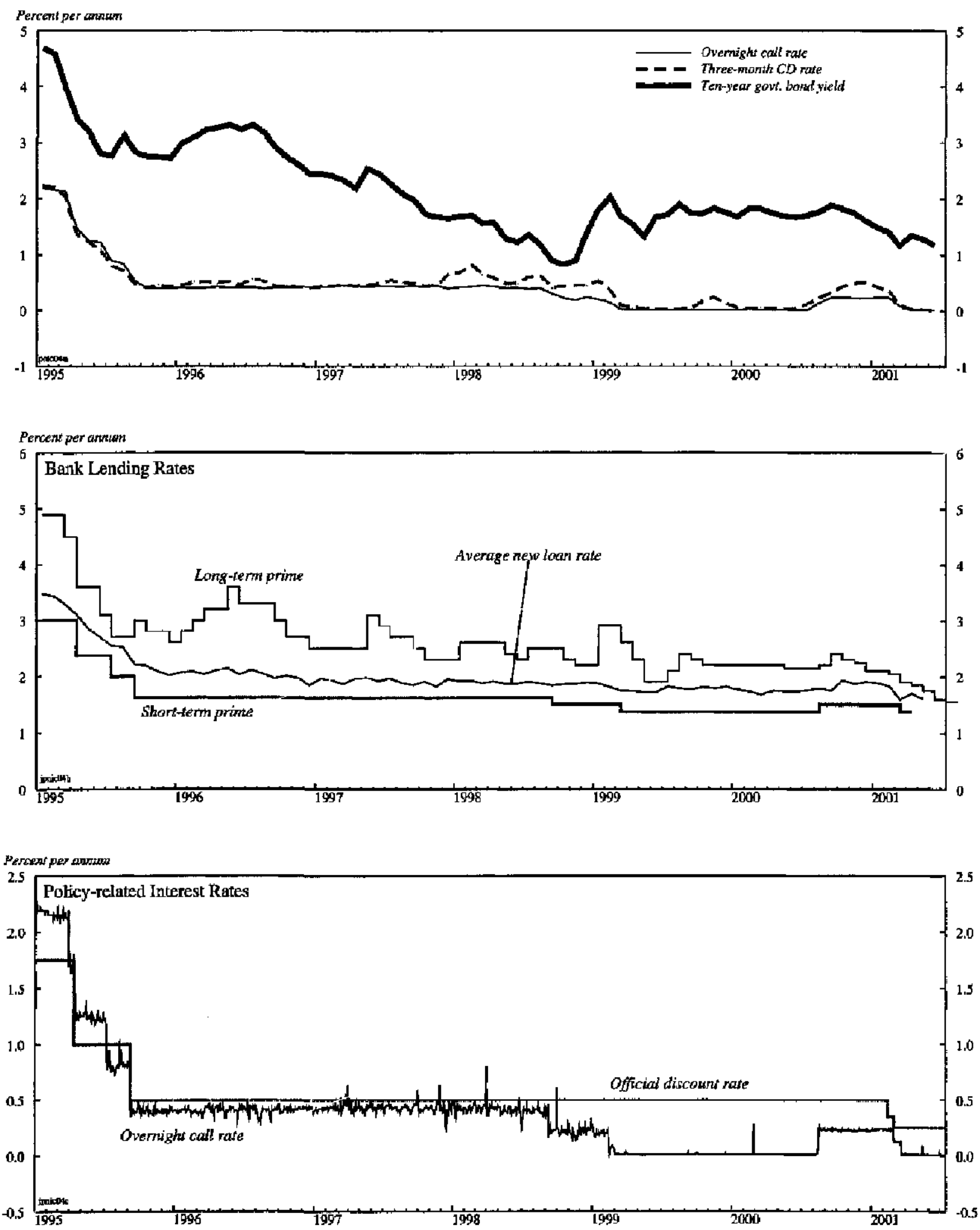

Source: Bank of Japan, Economic Statistics Monthly.

$1 /$ End-period.

CInternational Monetary Fund. Not for Redistribution 


\section{Funding conditions for the corporate sector appear to have eased since the} return to ultra-low interest rates (Figure III.2). Large parts of the corporate sector are still in the process of deleveraging, and issues of corporate securities in $2000 \mathrm{fell}$ to their lowest levels in more than 5 years. Following the BOJ's recent policy measures, however, brisk demand for bigher-yielding financial instruments has contributed to a more than 40 percent year-on-year increase in straight corporate bonds issued in April and May. The strong demand, combined with a still relatively limited supply of corporate debt, has continued to push risk premiums well below historical levels. The spread on short-term commercial paper rose from about 5 basis points to 30 basis points after the August 2000 rate hike, but has since retumed to almost zero. Premia on long-term corporate bonds, while broadly unchanged over the past year, are also substantially below those in other countries. For example, a spread of 20 basis points on a 10 -year AA-rated bond by a Japanese issuer compares to about 150 basis points paid by the same issuer in the United States.

\section{Despite the recent monetary} easing, monetary conditions do not appear excessively easy by past standards (Figure III.3). While underlying price deflation has indeed worsened, real rates remain substantially higher than during the past four years, with long-term yields closing the gap with the United States that persisted for several years. ${ }^{5} \mathrm{By}$ contrast, the depreciation of the yen (to around $¥ 120-125$ per U.S. dollar) has

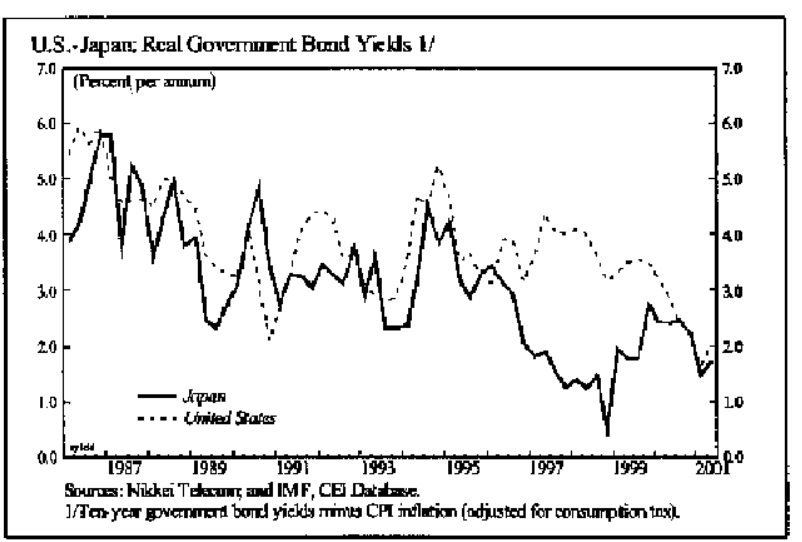
provided some boost to economic activity in recent months, with the ULC-based real effective exchange rate dropping by 15-20 percent since last fall. This has helped push the overall monetary conditions index (MCI) into weaker territory, although the MCI is only slightly lower than in the first half of 2000 when the economy looked considerably stronger.

\section{Money and Credit}

11. Underlying monetary base growth weakened in 2000. Base money declined by $¥ 181 / 2$ trillion during 2000 , particularly during the first two quarters of the year as $\mathrm{Y} 2 \mathrm{~K}$ operations (and possibly some financing bill purchases related to foreign exchange interventions) were unwound (Table III.1). While there was relatively little change during the third quarter, despite the lifting of the zero-interest rate policy (which led to some outflow of excess reserves from the $\mathrm{BOJ}$ ), the monetary base expanded again in the fourth quarter as the

\footnotetext{
${ }^{5}$ Real rates were sharply lower around the turn of the year (see middle panel of Figure III.3), but this remained temporary as a surge in energy prices subsequently reversed itself.
} 
Figure III.2. Japan: Funding Conditions for the Domestic Nonfinancial Sector
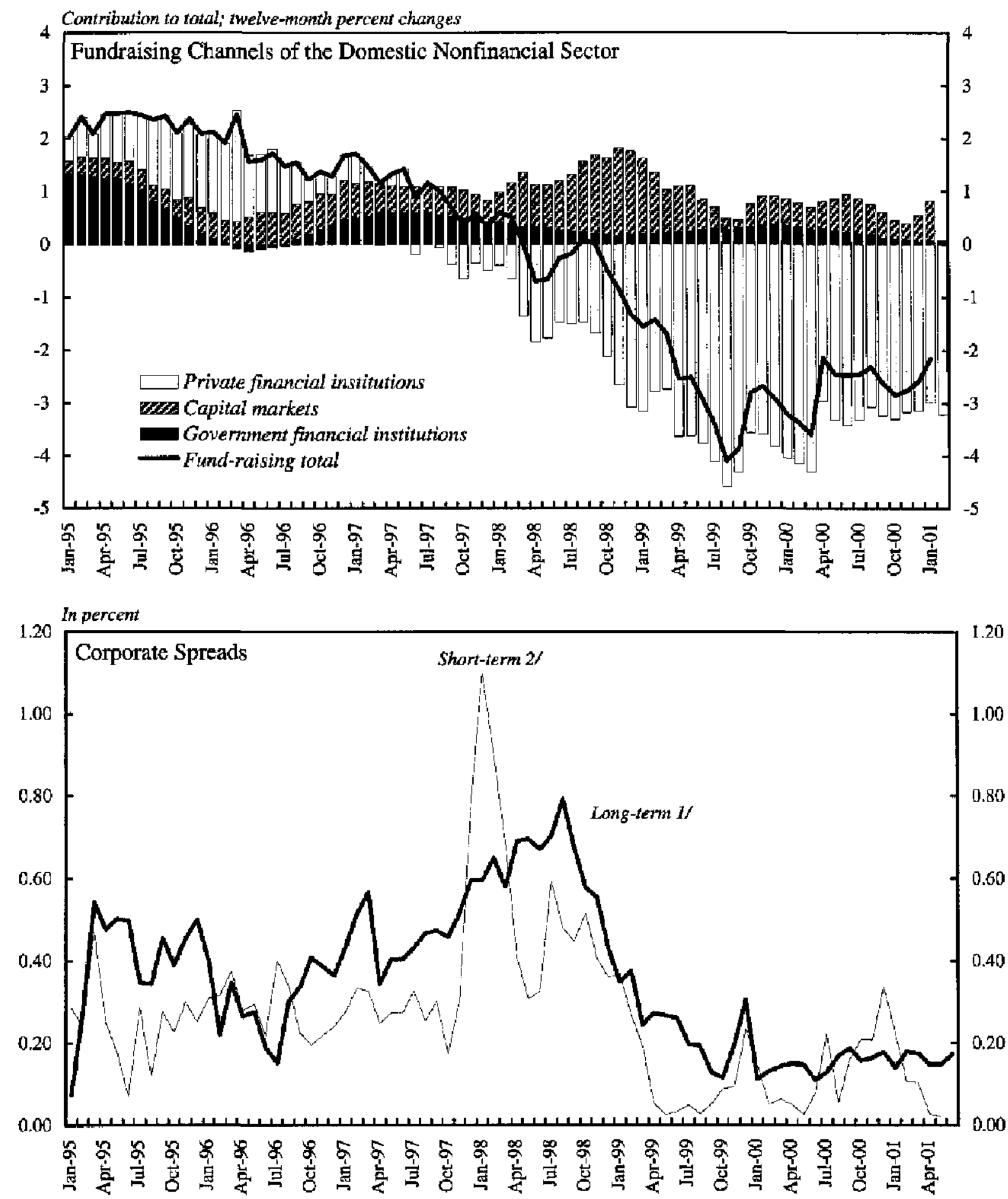

Source: WEFA, Nornura database.

1/ Twelve-year AA class industrial bond yield minus ten-year govenment bond yield.

$2 /$ Three-month commercial paper minus three-month repo (Gensaki rate). 
Figure III.3. Japan: Monetary Policy Stance, 1995-2001 1/
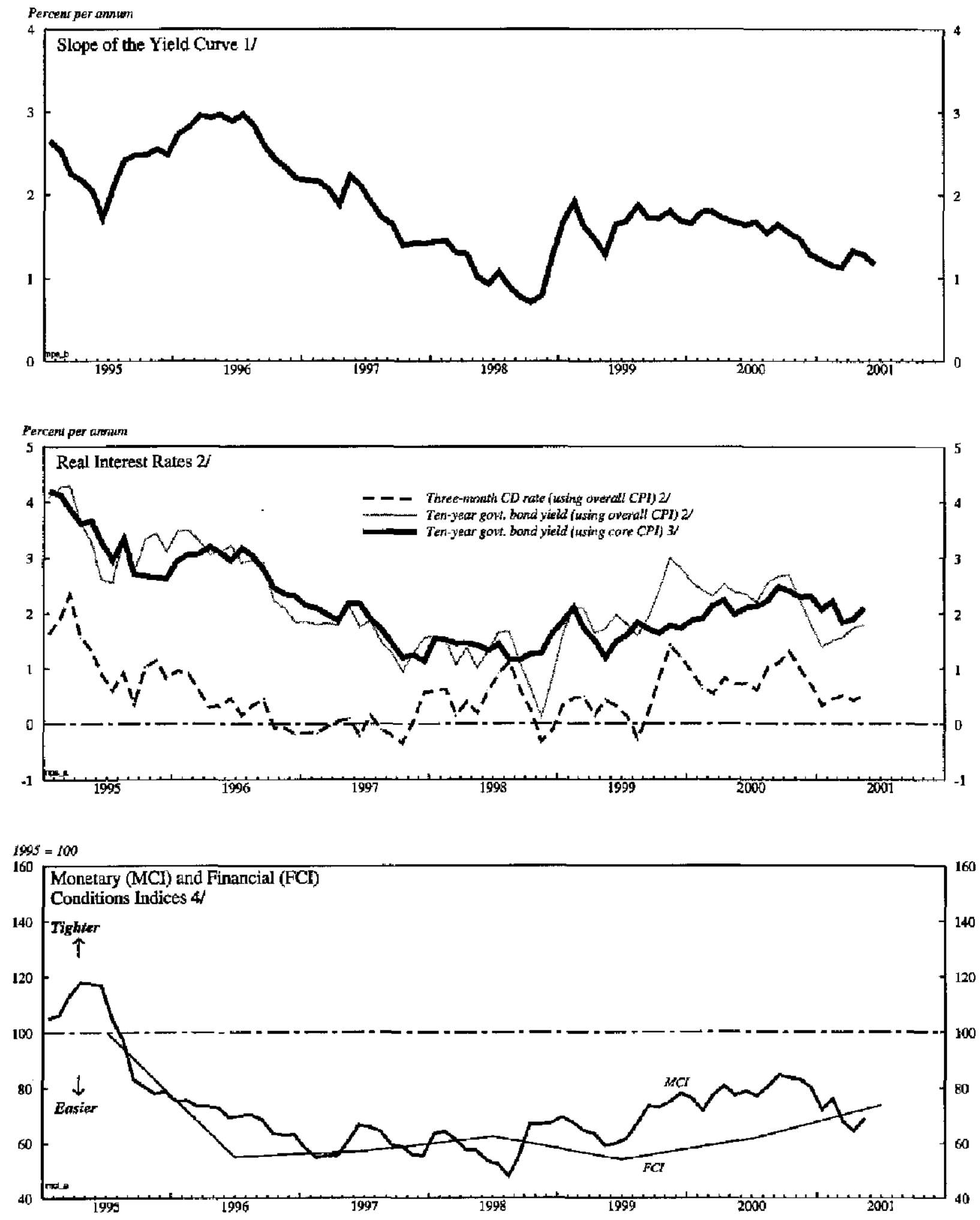

Sources: Nikkei Telecom; WEFA; and stafl estimetes.

1/ Ten-year govamment bond yleid minus tureo-month Genseaki rate.

$2 /$ Deflated by CPl adjusted for changes in indirect toxes and administered prices.

3/ Deflated by core CPI (excluding food and energy) adjusted for changes in indirect taxes and administered prices.

4 An increase indioates a tightening of monetary and thancibl oonditlons. The MCl is a weighted avarage of changas

in the real interest rate and the roal effective exchange rata. The $\mathrm{FCl}$ al $\mathrm{go}$ includes the change in the fiscal stance and the

siock price indext thls index is presented on an: annual bassis because quarterly fiscal data are not available. 
Table III.1. Japan: Monetary Base and the Bank of Japan's Transactions (Flow Table)

(In billions of yen)

\begin{tabular}{|c|c|c|c|c|c|c|c|c|c|}
\hline & \multirow[b]{2}{*}{1997} & \multirow[b]{2}{*}{1998} & \multirow[b]{2}{*}{1999} & \multirow[b]{2}{*}{2000} & \multicolumn{3}{|c|}{2000} & \multicolumn{2}{|c|}{2001} \\
\hline & & & & & II & III & $\mathrm{IV}$ & $\mathrm{I}$ & $\bar{\Pi}$ \\
\hline BOJ Transactions & $\ldots$ & 2,131 & 28,614 & $-18,531$ & $-14,971$ & 493 & 9,367 & $-5,803$ & 2,301 \\
\hline JGBs & $\ldots$ & 5,722 & 7,629 & 3,990 & $-3,908$ & $-2,234$ & 7,899 & $-1,542$ & $-5,938$ \\
\hline Qutright Purchases & $\ldots$ & 5,914 & 5,371 & 5,258 & 1,310 & 1,290 & 1,309 & 1,399 & 1,350 \\
\hline Redemptions & $\ldots$ & -416 & $-2,199$ & $-3,814$ & $-1,169$ & -693 & -323 & -270 & $-1,431$ \\
\hline Repo Transactions & $\ldots$ & 119 & 5,183 & 1,474 & $-3,955$ & $-3,212$ & 6,115 & $-2,658$ & $-5,878$ \\
\hline Purchases Under Repo Agreements & $\cdots$ & $-3,492$ & 0 & 0 & 0 & 0 & 0 & 0 & 0 \\
\hline Borrowing of JGBs Against Cash Collateral & $\ldots$ & 2,911 & 4,472 & 8,423 & $-1,717$ & 1,926 & 10,230 & 120 & $-2,158$ \\
\hline Sales to the Government, net (-) & $\ldots$ & 700 & 711 & $-6,949$ & $-2,238$ & $-5,138$ & $-4,115$ & $-2,778$ & $-3,719$ \\
\hline Other JGB Transactions & $\ldots$ & 106 & -726 & 1,073 & -94 & 380 & 798 & -12 & 21 \\
\hline TBs and FBs & $\ldots$ & 1,825 & 14,077 & $-8,510$ & $-10,269$ & 1,285 & -636 & 3,100 & $-1,732$ \\
\hline Underwriting & $\ldots$ & 225,474 & 167,799 & 16,873 & 3,516 & 1,684 & 2,250 & 1,900 & 2,137 \\
\hline Outright Transactions (net) & $\ldots$ & $-51,529$ & $-20,699$ & 1,082 & 208 & -127 & -32 & 1,222 & 18,251 \\
\hline Redemptions & $\ldots$ & $-169,705$ & $-154,559$ & $-29,309$ & $-10,873$ & $-2,031$ & $-1,748$ & $-2,528$ & $-2,197$ \\
\hline Repo Transactions (net) & $\cdots$ & $-2,415$ & 21,535 & 2,845 & $-3,120$ & 1,759 & $-1,105$ & 2,505 & $-19,923$ \\
\hline Outright Purchases of Bills & $\ldots$ & 1,166 & $-2,479$ & 410 & $-1,465$ & 1,301 & 2,183 & 5.811 & 5,042 \\
\hline Purchases of CP Under Repo Agreentents & $\ldots$ & 3,057 & 1,847 & $-5,917$ & $-1,970$ & -747 & 2,374 & $-1,96]$ & 612 \\
\hline Outright Sales of Bills Drawn by the BOJ (-) & $\ldots$ & $-14,431$ & 19,586 & $-2,807$ & $-1,297$ & 2,857 & -566 & $-1,579$ & $-2,115$ \\
\hline Loans and Discounts & $\ldots$ & 4,998 & $-6,059$ & $-3,140$ & .760 & -48 & 77 & $58]$ & -879 \\
\hline Loans Purșuant to Art. 33 of BOJ Law & $\ldots$ & 313 & $-1,031$ & -11 & -3 & -2 & -1 & 200 & -426 \\
\hline Loans Pursuant to Art. 38 of EOJ Law & $\ldots$ & $-3,070$ & 925 & $-1,068$ & -488 & -72 & -30 & 122 & -59 \\
\hline Loans to the DIC and Others & $\ldots$ & 7,755 & $-5,952$ & $-2,062$ & -269 & 26 & 108 & 260 & -394 \\
\hline Of which : Loans to the DIC & $\ldots$ & 7.755 & $-5,852$ & $-2,062$ & -269 & 26 & 108 & 260 & -394 \\
\hline Deposits of the Government (-) & $\ldots$ & -18 & $-5,438$ & $-3,428$ & 6,654 & $-2,477$ & -529 & $-12,690$ & 9,703 \\
\hline Others & $\ldots$ & -189 & -549 & 870 & $-1,956$ & 557 & $-1,436$ & 2,478 & $-2,392$ \\
\hline Monetary Base & $\ldots$ & 2,131 & 28,614 & $-18,531$ & $-14,971$ & 493 & 9,367 & $-5,803$ & 2,301 \\
\hline Banknotes in Circulation & $\ldots$ & 1,195 & 9,540 & $-2,008$ & $-1,802$ & 401 & 7,678 & $-4,723$ & 2,403 \\
\hline Coins in Circulation & $\ldots$ & 76 & 66 & 35 & -9 & 47 & 88 & -67 & 7 \\
\hline Current Account Balances & $\ldots$ & 860 & 19,008 & $-16,559$ & $-13,161$ & 45 & 1,602 & $-1,013$ & -109 \\
\hline Of which : Reserve Balances & $\ldots$ & 864 & 14,647 & $-13,526$ & $-8,676$ & 639 & 321 & -491 & 453 \\
\hline
\end{tabular}

Source: Bank of Japan, Financial and Economic Slatistics Monthly. 
BOJ injected $¥ 10$ trillion worth of liquidity to prepare for the introduction of RTGS. ${ }^{6}$ Once the effect of transactions spanning the year-end is excluded, however, underlying base money growth appears to have dropped markedly to $4-5$ percent year-on-year in the second half of 2000 (Figure III.4). This level was last reached during a period of financial turbulence in 1998 that preceded the introduction of the zero-interest rate policy.

\section{Trends so far in $\mathbf{2 0 0 1}$ indicate that the new policy framework has not had a large} impact on monetary base growth. Overcoming a temporary contraction in early 2001 (related to the unwinding of liquidity injections over the year-end), monetary base growth accelerated somewhat during the first half of 2001, reaching about $71 / 2$ percent in June, similar to the rate in the first half of 2000 . Nevertheless, liquidity needs appear to be broadly satisfied, as indicated by the BOJ's difficulties in meeting its reserves target through repo operations (gensaki) in April and May. A number of money market auctions suffered from a shortfall of bids, which prompted the BOJ to increase its outright purchases of short-term government securities, accounting for more than $¥ 18$ trillion in transactions during the second quarter. Moreover, to facilitate money market operations and liquidity management, the BOJ in May extended the range of instruments for its open market transactions to include sixmonths commercial bills and a range of medium-term government bonds. It also increased the number of counterparts for its bill purchasing operations, and the increment of bids at monetary auctions was lowered from 1 basis points to one tenth of a basis point.

\section{Broad money growth (M2+CDs) has picked up somewhat since hitting a 5-year} low last August, but remains constrained by banks' continuing reluctance to extend credit. The pace of decline in bank lending has slowed to about 4 percent in May, following a trough of 6 percent in early 2000 , but claims on the private sector have now been consistently shrinking since 1999 (Table III.2, Figure III.5). By contrast, claims on the government have risen sharply over the same period, reflecting the shift of bank funds into the JGB market. At the end of 2000, banks' claims on the government were 40 percent higher than the year before, following a 25 percent increase in 1999. Net foreign assets also grew by a quarter during 2000, which contributed almost 2 percent to overall broad money growth.

\footnotetext{
${ }^{6}$ The liquidity injections at the end of the year were conducted almost exclusively through repo operations. By comparison, the much larger operations needed to address Y2K concerns-involving close to $¥ 30$ trillion in liquidity-consisted mostly of so-called "dual”" operations (in which the BOJ purchased government securities spanning the year-end and withdrew overnight funds through the sale of BOJ bills). These developments are mirrored in the size of the BOJ's balance sheet.
} 
Figure III.4. Japan: Monetary Base
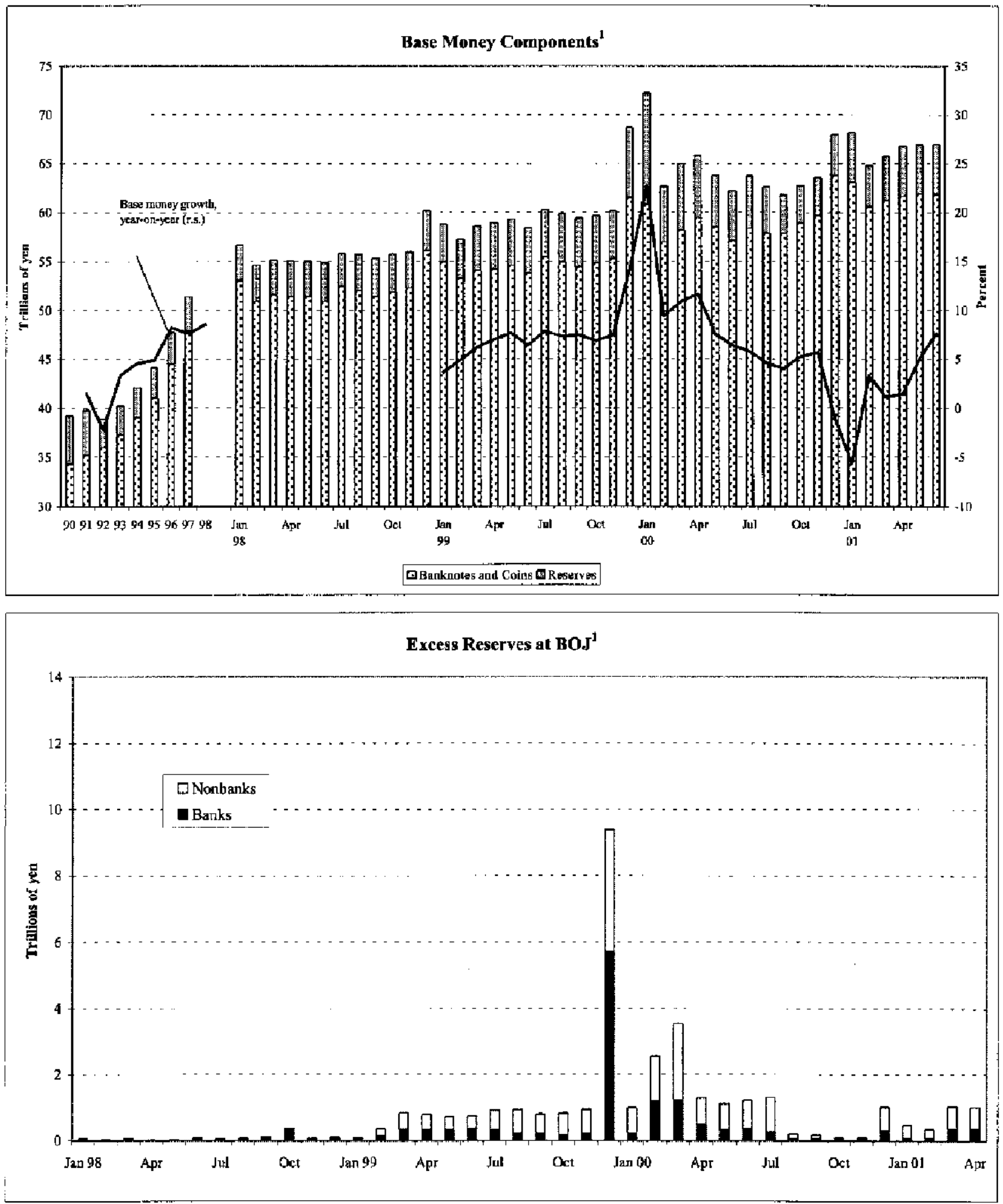

Souncc: Bank of Japan, Financial and Economic Stafistics (Monthly).

${ }^{1}$ Average outstanding 
Table III.2. Japan: Monetary Survey

\begin{tabular}{|c|c|c|c|c|c|c|c|}
\hline & \multirow[b]{2}{*}{1998} & \multirow[b]{2}{*}{1999} & \multicolumn{3}{|c|}{2000} & \multicolumn{2}{|c|}{2001} \\
\hline & & & Jun & Sep & Dec & Mar & May \\
\hline & \multicolumn{7}{|c|}{ (Period end; in billions of yen) } \\
\hline Monetary Survey & & & & & & & \\
\hline Foreign Assets (net) & 43,360 & 44,771 & 47,854 & 50,062 & 56,613 & 68,357 & 67,600 \\
\hline Domestic Credit & 693,781 & 714,035 & 721,222 & 726,544 & 732,860 & 727,088 & 744,592 \\
\hline Claims on Government (net) & 110,436 & 143,124 & 168,374 & 166,288 & 173,418 & 174,069 & 207,469 \\
\hline Clains on Private Sector & $\$ 83,345$ & 570,911 & 552,849 & 560,257 & $5,59,442$ & 553,020 & 537,123 \\
\hline $\mathrm{M} 2+\mathrm{CDs}$ & 621,494 & 638,011 & 636,190 & 638,410 & 651,319 & 652,815 & 646,428 \\
\hline Ml & 214,404 & 239,538 & 239,029 & 238,073 & 247,901 & 253,311 & 251,097 \\
\hline Quasi-Money + CDs & 407,090 & 398,472 & 397,161 & 400,338 & 403,418 & 399,504 & 395,331 \\
\hline Other Items (net) & 115,647 & 120,795 & 132,886 & 138,196 & 138,154 & 142,631 & 165,763 \\
\hline \multicolumn{8}{|l|}{ Accounts of Monetary Authorities } \\
\hline Foreign Assets (short-term, net) & 14,469 & 21,564 & 26,293 & 27,059 & 33,007 & 37,219 & 38,300 \\
\hline Claims on Government (net) & 30,283 & 41,985 & 40,437 & 34,107 & 30,130 & 20,397 & 47,126 \\
\hline Claims on Deposit Money Banks & 15,277 & 14,596 & 3,965 & 4,647 & 8,105 & 15,343 & 13,933 \\
\hline Unclassified Assets (net) & 4,307 & 11,477 & $-6,756$ & -795 & 2,031 & $-4,936$ & $-32,515$ \\
\hline Reserve Money & 64,336 & 89,622 & 63,940 & 65,018 & 73,273 & 68,023 & 66,844 \\
\hline \multicolumn{8}{|l|}{ Accounts of Depesit Money Banks } \\
\hline Cash and Deposits with the Bank of Japan & 10,026 & 30,217 & 9,687 & 10,024 & 11,284 & 10,353 & 10,277 \\
\hline Foreign Assets & 109,074 & 77,745 & 74,744 & 75,917 & 84,897 & 97,414 & 90,375 \\
\hline Claims on Government & 80,153 & 101,139 & 127,936 & $132,18 !$ & 143,288 & 153,672 & 160,343 \\
\hline Claims on Private Sector, etc. & 583,345 & $570,91 \mathrm{~L}$ & 552,849 & 560,257 & 559,442 & 553,020 & $\$ 37,123$ \\
\hline & \multicolumn{7}{|c|}{ (Year-an-year change, in percent) } \\
\hline Domestic Credit & 2.6 & 2.9 & 3.8 & 4.2 & 2.6 & 2.4 & 3.9 \\
\hline Claims on Government (net) & 13.7 & 29.6 & 33.9 & 26.9 & 21.2 & 17.3 & 26.3 \\
\hline Monetary Authorities & 4.1 & 38.6 & 38.3 & 16.7 & -28.2 & -49.4 & 32.4 \\
\hline Banks & 17.7 & 26.2 & 32.5 & 29.9 & 41.7 & 42.1 & 24.6 \\
\hline Claims on Private Sector & 0.8 & -2.1 & -2.8 & $-1 . i$ & -2.0 & -1.6 & -2.7 \\
\hline $\mathrm{M} 2+\mathrm{CDs}$ & 4.0 & 2.7 & 2.2 & 3.3 & 2.1 & 3.0 & 3.1 \\
\hline M1 & 5.0 & 11.7 & 7.9 & 8.4 & 3.5 & 6.6 & 7.5 \\
\hline Quasi-Money + CDs & 3.5 & -2.1 & -1.0 & 0.5 & 1.2 & 0.8 & 0.5 \\
\hline \multirow[t]{2}{*}{ Reserve Money } & 3.6 & 39.3 & 5.4 & 6.3 & -18.2 & -9.8 & 6.7 \\
\hline & \multicolumn{7}{|c|}{ (Contributions to broad money growth, in percent) } \\
\hline Foreign Assets (net) & -1.7 & 0.2 & 0.3 & 0.6 & 1.9 & 3.1 & 3.0 \\
\hline Donestic Credit & 3.0 & 3.3 & 4.3 & 4.7 & 3.0 & 2.7 & 4.5 \\
\hline Claims on Government (net) & 2.2 & 5.3 & 6.8 & 5.7 & 4.7 & 4.0 & 6.9 \\
\hline Monetary Authorities & 0.2 & 1.9 & 1.8 & 0.8 & -1.9 & -3.1 & 1.8 \\
\hline Banks & 2.0 & 3.4 & 5.0 & 4,9 & 6.6 & 7.2 & 5.0 \\
\hline Claims on Private Sector & 0.8 & -2.0 & -2.6 & -1.0 & -1.8 & -1.4 & -2.4 \\
\hline Other Items (net) (-) & 2.7 & -0.8 & -2.4 & -2.0 & -2.7 & -2.8 & -4.4 \\
\hline $\mathrm{M} 2+\mathrm{CDs}$ & 4.0 & 2.7 & 2.2 & 3.3 & 2.1 & 3.0 & 3.t \\
\hline MI & 1.7 & 4.0 & 2.8 & 3.0 & 1.3 & 2.5 & 2.8 \\
\hline Quasj-Money + CDs & 23 & -1.4 & -0.7 & 0.3 & 0.8 & 0.5 & 0.3 \\
\hline Reserve Money & 0.4 & 4.1 & 0.5 & 0.6 & -2.6 & -1.2 & 0.7 \\
\hline
\end{tabular}

Source: Bank of Japan, Financial and Economic Statisfics Monfhly. 
Figure III.5. Japan: Money and Credit Growth, 1995-2001
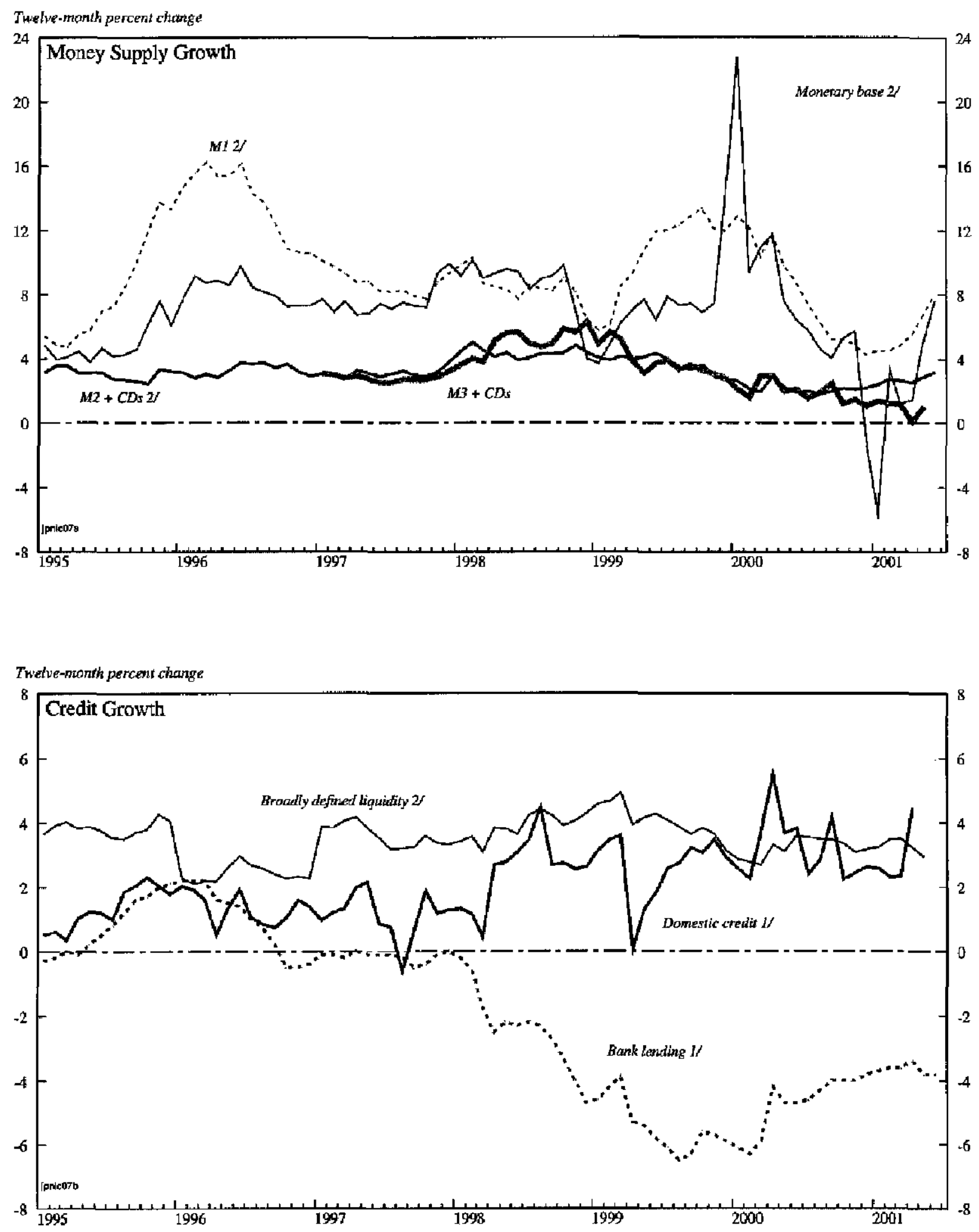

Sources: Bank of Japan, Esonomto Stastistics Monthly. 
14. Growth rates of other monetary aggregates have remained similarly subdued:

- In line with base money growth, narrow money (M1) expanded strongly in 1999 through mid-2000, but is now recovering only slowly from a sharp deceleration in late 2000.

- Growth in M3+CDs has fallen to below 1 percent in May, likely reflecting the maturation of postal savings deposits which are partly flowing out of the banking system.

- Broadly-defined liquidity has expanded at a more stable pace, but its current growth rate of 3 percent is also somewhat lower than in recent years.

15. Money multipliers have been relatively stable over the past two years. Excluding the volatile movements in money multipliers caused by Y2K and RTGS-related liquidity injections (as well as end-FY1999 concerns), broader monetary and liquidity aggregates have exhibited a relatively stable trend relative to reserve money since 1998 (top panel of Figure III.6). ${ }^{7}$ This would be consistent with the view that the government's bank support packages in 1998/99 were successful in shoring up confidence in the banking system as a whole, and that "new" financial intermediaries (e.g., security investment trusts and other nonbanks) are only slowly increasing their share in financial intermediation. ${ }^{8}$

16. Within broadly-defined liquidity components, some reallocation of funds away from monetary assets appears to be underway. The attractiveness of time deposits and CDs appears to have suffered in recent years, as evidenced by the decline of the share of quasi-money in broad money (middle panel of Figure III.6). However, these funds are no longer flowing into broader M3 compenents (e.g., deposits in the postal system, cooperativetype institutions, or trust money in domestic banks), which they did during most of the $1990 \mathrm{~s}^{9}$ Instead, nonmonetary items that are still part of broadly-defined liquidity (e.g., investment trusts held in banks, JGBs held by non-banks, etc.) bave recently risen faster than M3 components, which seems to be a consequence of the higher relative returns offered by such instruments (lower panel of Figure II.6).

\footnotetext{
${ }^{7}$ Reflecting inter alia problems in the banking sector, money multipliers have generally declined during the 1990s.

${ }^{8}$ The slow growth in importance of "new" intermediaries is confirmed by the recently released flow of funds statistics for FY1999 (see BOJ Quarterly Bulletin, February 2001).

${ }^{9}$ For example, with the maturation of high-yielding teigaku deposits, the share of postal savings deposits in broadly-defined liquidity has fallen from $203 / 4$ percent in early 2000 to 19 percent in April 2001.
} 
Figure IП.6. Japan: Developments in Money Multipliers, 1990-2001 ${ }^{1}$

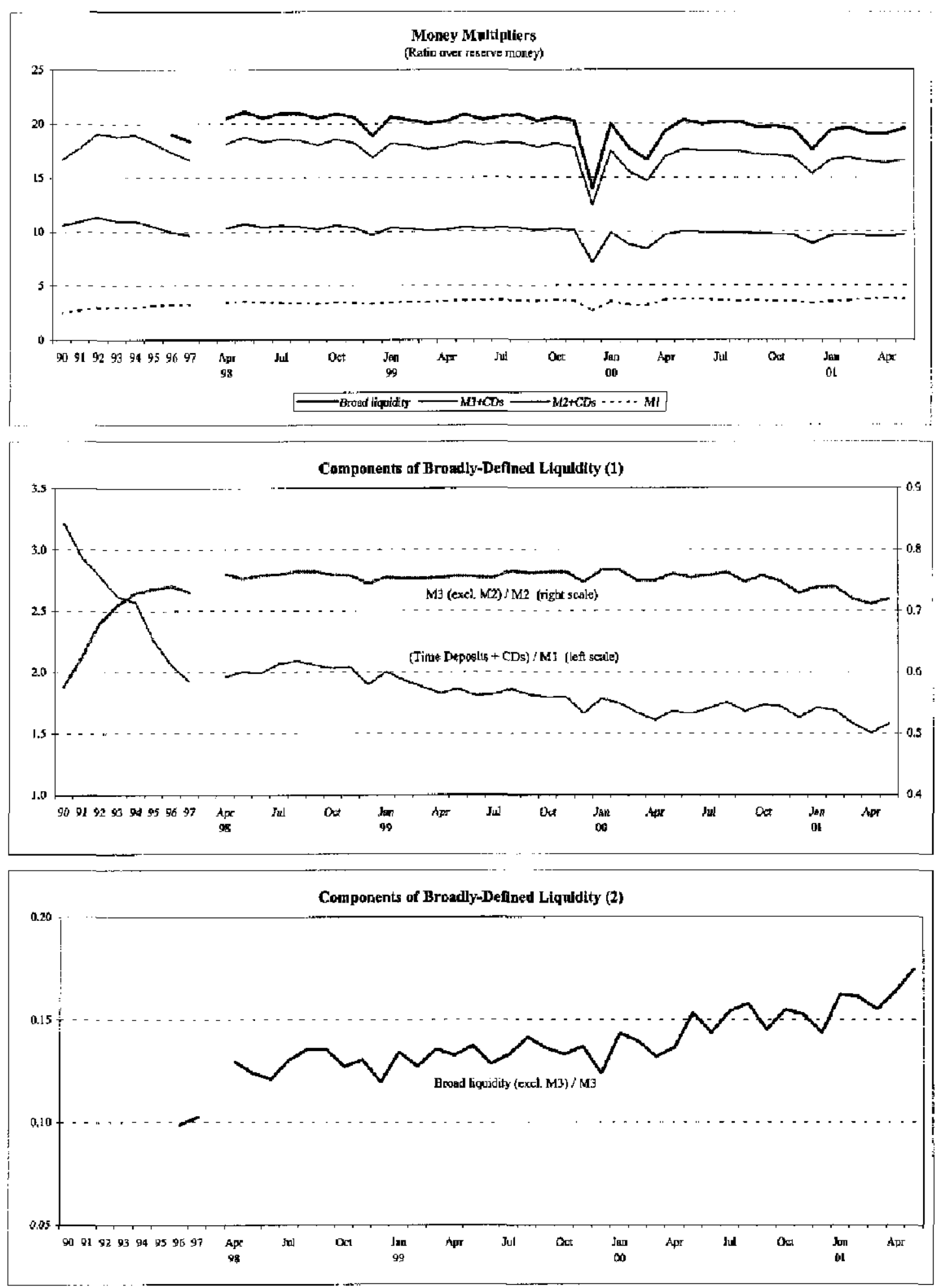

Source: Bank of Japan, Fnanctal and Economic Statistics (Monthly).

${ }^{1}$ End of period, 


\section{Outlook}

\section{The new policy framework} provides the BOJ with the scope to ease the policy stance further. The expansion of reserve balances by around $¥ 1$ trillion has been maintained through repo operations and purchases of short-term government securities, and the BOJ has so far seen no need to step up JGB purchases. The BOJ's commitment to keep the policy in place until deflation has been eliminated appears to have had its desired effect, as

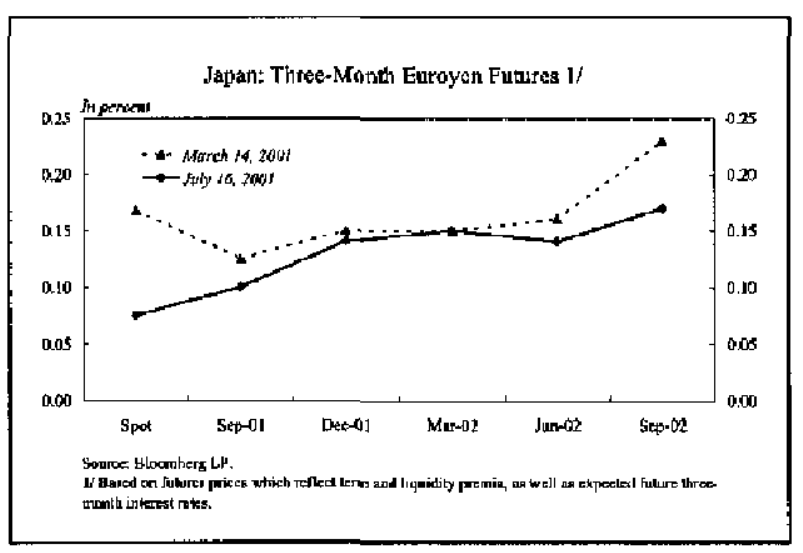
markets are expecting short-term interest rates to remain at their floor for quite some time (as indicated, e.g., by the flattening of the yield curve and the decline in Euroyen futures). However, most market participants take the view that the BOJ will need to do more to eliminate deflation within a reasonable timeframe, which underscores the need for making use of the flexibility afforded by the new policy framework. 


\section{Financial System Issues ${ }^{1}$}

1. After a period of relative calm following the last round of public capital injections in 1999, a deteriorating macroeconomic environment has again exposed underlying structural problems in the banking sector. Notwithstanding some progress in restructuring banking operations and raising profitability, including in the context of large mergers, reported problem loans have remained high and concerns about asset quality remain. In early 2001, a sharp drop in the stock market reinforced concerns over bank capitalization, prompting the government to announce an emergency package aimed at disposing of major banks' bad loans and reducing their exposure to equity market risk. Details relating to the measures in the package were specified in a policy blueprint announced by the Council for Economic and Fiscal Policy (CEFP) in mid-June 2001. Looking ahead, the introduction of mark-to-market accounting in FY2001 and the shift from blanket to partial deposit insurance in April 2002 could present formidable challenges for weaker banks, including some regional institutions and credit cooperatives. ${ }^{2}$

\section{The life insurance sector has also been adversely affected by the economic} slowdown, which brought deteriorating revenues, asset quality, and yield spreads during the past year. The major insurance companies have held up reasonably well so far, but a string of failures among mid-sized insurance companies has highlighted the increasing vulnerability of the sector. Entry by banks and the opening of some parts of the industry to cross-sectoral competition--concluding the Big Bang reforms--will raise competitive pressures over time and has already led to greater cooperation through mergers and alliances. Going forward, further consolidation is likely to occur.

\section{A. Bank Vulnerability}

\section{Three years after Japan's banking crisis, initial hopes that bank restructuring} supported by public capital injections would restore banks to financial health have yet to be realized. Major banks, regional banks, and credit cooperatives continue to be burdened by sizable problem loans. In the view of the Financial Services Agency (FSA), Japan's financial supervising agency, banks have adequately provisioned against nonperforming loans (NPLs), but some private analysts estimate that banks' uncovered loan loss exposure remains excessively large-equivalent in the aggregate to half of Tier-1 capital for major banks and more than 100 percent of Tier-1 capital for regional banks. Analysts have also raised concerns about the quality of regulatory capital and low bank profitability. Banks also remain highly exposed to market volatility owing to their large equity and government bond holdings. Market fluctuations will directly affect bank capital with the introduction of markto-market accounting, effectively from September 2001, the first reporting period under the new regulations.

\footnotetext{
${ }^{1}$ Prepared by Martin Muhleisen (x38686).

${ }^{2}$ The financial year begins April 1.
} 


\section{The Bad Loan Problem}

4. Despite banks' continued efforts to write off NPLs in FY2000, outstanding problem loans rose slightly as new NPLs emerged faster than expected. Banks recognized an estimated $¥ 5-6$ trillion in fresh bad loans amid high-profile corporate failures and a sharp increase in bankruptcies among smaller companies. Banks also participated in several large-scale debt forgiveness packages and had to cover falling collateral values as land prices continued to decline. Moreover, progress in the implementation of loan classification standards has also contributed to the need for additional provisioning. As a result of these factors, loan loss charges for major banks amounted to $¥ 4.3$ trillion for the past financial year--2.6 times initial estimates and comparable to credit costs in the previous year.

\section{As of September 2000, gross NPLs for major and regional banks according to} the Financial Reconstruction Law (FRL) standard amounted to $¥ 32$ trillion, compared to $¥ 11-12$ trillion in general and specific reserves and an undisclosed amount of collateral (TabJe IV.1). ${ }^{3}$ A large amount of loans which were lent to borrowers classified as "needing attention" may be at risk of becoming nonperforming, however recently released data--based on banks' self-assessment of asset quality-show that the total face value of loans by major and regional banks to borrowers whose financial condition requires attention or who are either bankrupt or close to bankruptcy amounts to $¥ 111$ trillion, of which $¥ 48$ trillion is covered by "superior" collateral (Table IV.2). The remaining $¥ 63$ trillion is either covered by "ordinary" collateral or unsecured. ${ }^{4}$ Once credit cooperatives are included (using data as of March 2000), the total value of loans to classified borrowers rises to $¥ 151$ trillion (30 percent of GDP), of which $¥ 70$ trillion is covered by superior collateral. ${ }^{5}$

\section{Notwithstanding concerns that have been raised over the large amount of} potential problem loans, the FSA takes the view that currently performing loans to borrowers requiring attention are a source of income for the banks and pose manageable risks. The FSA has advised banks to adjust lending policies and conditions according to the credit risk of the borrower, and they see banks as having made progress in this area. In addition, the FSA has expressed confidence that banks are well advanced in strengthening loan classification and provisioning practices to internationallycomparable levels, citing endorsements by external auditing firms that regard banks' accounting practices as adequate. Following intensive on-site examinations for all major and regional banks, the FSA has reported increasing compliance with its 1999 bank

\footnotetext{
${ }^{3}$ The FRL definition of NPLs includes claims on borrowers in or near bankruptcy and claims on borrowers requiring special attention (mainly those with restructured loans and loans past due by more than three months).

${ }^{4}$ Superior collateral includes deposits and other financial instruments (e.g., government bonds) of high quality that are easily disposable. Ordinary collateral includes other types of disposable collateral (e.g., real estate).

${ }^{5}$ Loans to classified borrowers by all deposit-taking institutions included $¥ 48$ trillion in NPLs as of September 2000 (see Table IV.2).
} 
Table IV.1. Japan: Problem Loans

\begin{tabular}{|c|c|c|c|c|c|c|}
\hline & $\begin{array}{c}\text { March } \\
1999\end{array}$ & $\begin{array}{c}\text { March } \\
2000\end{array}$ & $\begin{array}{c}\text { September } \\
2000\end{array}$ & $\begin{array}{c}\text { March } \\
1999\end{array}$ & $\begin{array}{l}\text { March } \\
2000\end{array}$ & $\begin{array}{c}\text { September } \\
2000\end{array}$ \\
\hline & \multicolumn{3}{|c|}{ (in triltions of yen) } & \multicolumn{3}{|c|}{ (in pencent of total loans) } \\
\hline \multicolumn{7}{|l|}{ Banks' solf assessment of asset quality 1 / } \\
\hline Deposit-taking institutions & 80.6 & 81.7 & $\ldots$ & 11.6 & 12.1 & $\ldots$ \\
\hline Banks & 64.3 & 63.3 & 63.9 & 11.7 & 11.8 & 12.0 \\
\hline Major banks & 41.6 & 40.9 & 40.9 & 11.6 & 11.7 & 11.8 \\
\hline Regional banks & 22.7 & 22.5 & 23.1 & 11.7 & 12.1 & 12.5 \\
\hline Cooperative-type financial institutions & 16.3 & 18.4 & $\cdots$ & 11.4 & 13.4 & $\ldots$ \\
\hline \multicolumn{7}{|l|}{ Nonperforming loans; FRL. standard 2/ } \\
\hline Deposit-taking institutions & $\ldots$ & 42.2 & $\ldots$ & $\ldots$ & 6.6 & $\ldots$ \\
\hline Banks & 33.9 & 31.8 & 32.1 & 6.2 & 5.9 & 6.2 \\
\hline Major banks & 21.9 & 20.4 & {$[9.1$} & 6,1 & 5.8 & 5.7 \\
\hline Regional banks & 12.0 & 11.4 & 13.0 & 6.2 & 6.2 & 7.1 \\
\hline Cooperative-type financial institutions & $\ldots$ & 10.4 & $\ldots$ & $\cdots$ & 9.9 & $\ldots$ \\
\hline \multicolumn{7}{|l|}{ Nonperforming loass: FBA standard 3 / } \\
\hline Deposit-taking institutions & 38.7 & 41.4 & $\ldots$ & 6.0 & 6.6 & $\ldots$ \\
\hline Banks & 29.6 & 30.4 & 31.1 & 5.8 & 6.1 & 6.4 \\
\hline Major banks & 20.3 & 19.8 & 18.5 & 6.3 & 6.2 & 6.2 \\
\hline Regional banks & 9.4 & 10.6 & 12,5 & 5.0 & 5.9 & 5.9 \\
\hline Cooperative-type financial institutions & 9.0 & 11.0 & $\cdots$ & 5.7 & 8.3 & $\ldots$ \\
\hline \multicolumn{7}{|l|}{ Memorandum Items } \\
\hline & \multicolumn{3}{|c|}{ (in trillions of yen) } & \multicolumn{3}{|c|}{ (in percent of NPL) $4 /$} \\
\hline \multicolumn{7}{|l|}{ Speçfic reserves } \\
\hline Deposit-taking institutions & 14.8 & 11.5 & $\ldots$ & $\ldots$ & 27.8 & $\ldots$ \\
\hline Banks & 11.2 & 8.4 & 7.7 & 37.8 & 27.7 & 24.8 \\
\hline Major banks & 6.8 & 5.0 & 4.4 & 33.6 & 25.3 & 23.8 \\
\hline Regional banks & 4.4 & 3.4 & 3.3 & 46.9 & 32.1 & 26.3 \\
\hline Cooperative-type fitrancial institutions & 3.6 & 3.1 & $\cdots$ & $\cdots$ & 28.2 & $\cdots$ \\
\hline General reserves (major banks) & 2.3 & 2.3 & 2.4 & 11.4 & 11.6 & 13.0 \\
\hline
\end{tabular}

Source: Finatwial Services Agency, FitchIBCA, and staff calculations.

I/ Uruder the self-assessment standard, banks report all loans to borrowers in or near bankruptcy or in need of attention, with the exception of class I loans (which are covered by superior collateral).

2/ The FRL standard requires batiks to report all loans to batiktupt or nearly bankrupt borrowers, as well as loans to borrowers requiring special attention, notwithstanding the quality of collateral.

3/ The standard used by the Federation of Bankers' Associations (FBA), which has been longest in use, is somewhat narrower than the FRL standard. It does not include guarantees, foreign currency assets, and other claims.

4/ Relative to nonperforming loans according to the FBA standard. 
Table IV.2. Japan: Classification of Bank Loans

(in trillions of yen)

\begin{tabular}{llrl}
\multicolumn{5}{c}{ Loan Class 1/ } & \\
\hline 1 & 2 & 3 & 4
\end{tabular} Total

Deposit-Taking Financial Institutions (March 2000)

1. Borrowers needing attention

Of which:

1b. Borrowers requiring special attention

2. Borrowers in danger of bankruptcy

3. Bankrupt or technically bankrupt borrowers

Total Loans

Of which:

Nonperforming Loans $(1 \mathrm{~b}, 2,3) 2 f$
$53.0 \quad 63.9$

n.a.

9.4

7.2

583.2

19.0

25.5

3.5

0.01
1169

14.0

20.5

664.5

48.0

Major and Regional Banks (September 2000)

1. Borrowers needing attention

Of which:

1b. Borrowers requiring special attention

2. Borrowers in danger of bankruptcy

3. Bankrupt or technically bankrupt borrowers

Total Loans

Of which :

Nonperforming Loans (1b, 2, 3) 2 /

$$
36.7
$$

50.5

n.a.

7.0

5.6

2.7

...

\section{7}

4.9

0.02

0.01

457.5

61.0

2.7

0.01

521.2

$12.7 \quad 20.1$

2.7

0.01

Source: Financial Services Agency, April 2001.

1/ Class 1 loans include all loans to normal borrowers, as well as other loans that are covered by superior collateral or guarantees. Class 2 loans include all remaining loans to borrowers requiring attention, as well as loans to borrowers in or in danger of bankruptcy that are covered by ordinary collateral. Class 3 loans include all rernaining loans to borrowers in danger of bankruptcy, as well as remaining loans to bankrupt borrowers with doubtful recovery value. Class 4 loans are regarded as unrecoverable.

2/ The nonperforming loans are slightly larger than reported in Table TV.1, owing to differences in coverage and loan reclassification in between publication dates. 
inspection manual, which closely mirrors supervisory practices in other major industrial countries. Moreover, the FSA enforces stringent provisioning requirements for nonperforming loans, with latest data showing that major banks' loans to special attention borrowers are more than 50 percent covered by either collateral, loan guarantees or loan loss provisions. Loans to borrowers in danger of bankruptcy show coverage in excess of 80 percent, and loans to bankrupt borrowers are fully covered.

\section{The FSA does not see a need for a further tightening of classification or}

provisioning standards. In particular, it believes that forward-looking provisioningbeyond the level consistent with historical loss rates-would be inconsistent with international accounting standards and practices, and could exacerbate the already procyclical tendency of bank lending activities. Moreover, the FSA is concerned that overly conservative provisioning could lead to an excessive reduction of profits and thus result in an infringement of shareholder interests. It also argues that provisioning should adhere to the Commercial Law and generally accepted accounting practices. Nevertheless, the FSA plans to continue efforts to ensure strict enforcement of existing standards and the strengthening of banks' risk management capabilities in the context of future examinations.

\section{By contrast, market analysts consider that the banking system is substantially} underprovisioned against potential loan losses. Using various methods, different analysts estimate that major and regional banks need to incur an additional $¥ 20-30$ trillion (5-6 percent of GDP) in additional loan loss charges to reach adequate provisioning levels (Box VI.1). These charges compare to total Tier-1 capital of $¥ 33$ trillion. The basis for this assessment is their view that (1) the average loan-loss rate on existing NPLs may prove to be higher than the present rate of provisioning, and (2) a substantial amount of so-called "grayzone" loans - loans to borrowers requiring attention that have not yet been classified as NPLs-may become nonperforming and incur losses.

- Loss rate on reported NPLs. On the basis of the loss rate on loans that have already been fully removed from banks' balance sheets, analysts expect loss rates for existing NPLs to exceed provisioning requirements on the non-collateralized part of NPLs, which are between 15 and 70 percent, depending on the classification of the borrower. ${ }^{6}$ Moreover, notwithstanding a 30 percent haircut on collateral values imposed by the FSA, analysts consider that the value of collateral on bank balance sheets is often overstated: write-offs of land values have not kept up with the decline in land prices, and sales typically occur at depressed prices, owing to the absence of a liquid real estate market. Analysts estimate that these factors could give rise to further losses of $¥ 10-20$ trillion on existing NPLs.

- Losses on gray zone loans. In addition to reported NPLs, analysts expect substantial losses from "gray zone" loans. These loans are typically owed by severely indebted companies concentrated in some of the weakest sectors of the economy (real estate,

\footnotetext{
${ }^{6}$ Loans that are fully provisioned up to the value of collateral and guarantees can be carried on the balance sheet with zero value ("partial write-off"). The loans remain on the books until all claims relating to the loan have been resolved ("final disposal"), which can take years unless the loan is sold or forgiven.
} 


\section{Box IV.1. Japan-Methods to Estimate Future Bank Loan Losses}

In view of banks' past loss experience, market analysts generally consider that current provisioning levels are inadequate to cover losses that might arise both from reported nonperforming loans (NPLs) and from loans to troubled borrowers that might become nonperforming in the near future. Analysts base their estimates on how much more provisioning will be needed on different methods, partly depending on the quality of loan data at their disposal:

- One approach is to compare the ratio of bank loans to GDP at the height of the bubble to its long-term average, which gives a rough measure for the amount of excess loans that needs to be written off. Uncovered loan losses can be calculated by subtracting the cumulative amount of loan losses that has already been recognized.

Some analysts have applied assumed loss rates to the amount of outstanding nonperforming and "gray zone" loans. These rates are assumed to increase sharply from historical levels (which can be calculated from bank's loan books), owing to a weakening economy, a concentration of loans in weak sectors, less room for evergreening, and a tougher approach by bank regulators. Analysts generally refer to the experience with nationalized banks where inspectors discovered a much larger amount of NPLs than had been classified as such by the banks.

- Another approach, which takes account of the fact that banks continue to experience losses on collateral as long as a loan has not been fully removed from the balance sheet (which may take several years), applies a common loss rate to all loans that have been reported non-performing since the end of the bubble. Estimates for the loss rate can be based on the relatively few loans that have been resolved by loan disposal agencies (such as the CCPC, an institution that resolves credit cooperative loans), or on prices for bad loans on the secondary market.

- Finally, one approach is to modify loss rates according to the year in which bank loans have been taken out. This also takes account of the fact that losses relate to the decline of collateral values over the lifetime of the loan.

Details regarding the calculations are often proprietary, which makes it difficult to evaluate individual assumptions and estimates on their merit. However, the estimates broadly converge to the conclusion that major and regional banks may hold some $¥ 20$ - 30 trillion in unrecognized loan losses. 
construction, retail, financial and other services), many of which would not be able to survive if interest rates rose significantly from their present low levels. Loans to such companies account for more than half of all major bank loans and 85 percent of all NPLs. ${ }^{7}$ Analysts question whether these loans are adequately classified and provisioned against, particularly as loan officers still appear reluctant to downgrade borrowers, either on account of long-established relationships or because of the implications for provisioning and new lending. Moreover, favorable loan classifications sometimes depend on guarantees by other affiliates of parent companies, which could themselves become impaired. Analysts expect that a further slowdown in the economy could lead to a transformation of many gray zone loans into NPLs, necessitating $¥ 10$ - 15 trillion in additional loan loss charges.

9. Differences in view on the magnitude of the NPL problem largely reflect different assumptions on future loss rates, which in turn depend strongly on the future course of the economy. To illustrate the range of possible outcomes, Table IV.3 shows the amount of uncovered losses for major and regional banks under various scenarios. The table loosely corresponds to a simulation by a major credit rating agency, which has analyzed possible losses across different loan categories under varying macroeconomic conditions. ${ }^{8}$ Going beyond the estimation problem, however, there are concerns whether adherence to internationally accepted inspection practices is sufficient under Japan's deflationary environment to reflect the full scale of the bad loan problem. There is likely a need for a more forward-looking approach than typically required by such practices, given the erosion of collateral values and the sharp increase in real debt burden in an environment of price deflation that are unique in recent economic history. Since Japanese banks may not yet have the credit management systems in place to deal with these unusual circumstances, a risk remains that their assessments of the true quality of their loan portfolio are still too optimistic.

\section{Weak Capital and Low Profitability}

10. Some market analysts consider that if bad loans were provisioned in accordance with their estimates, a number of weaker banks could become technically insolvent and many others would probably fall below minimum capital requirements. Major banks have achieved the most progress in provisioning for or writing off bad loans, accounting for an estimated 75 percent of around $¥ 70$ trillion in cumulative credit costs for all banks since the end of the bubble. Nevertheless, market analysts estimate that major banks' aggregate future loan loss exposure equals about half of their Tier-1 capital. Since regional banks remain relatively less well

\footnotetext{
${ }^{7}$ Loans to just three sectors (real estate, construction and retail) account for about a quarter of all loans and almost half of bad loans.

${ }^{8}$ FitchIBCA (May 2001), Japanese Banks: Loan Loss Simulation for Japanese Banks Based on Newly Disclosed Problem Loan Data. According to Fitch, the macroeconomic scenario underlying the worst case scenario in Table IV.3 corresponds to a sharp recession, followed by meaningful structural change and a gradual economic recovery.
} 
Table IV.3. Japan: Sensitivity Analysis for Uncovered Loan Losses of Major and Regional Banks

(Loan amounts are based on September 2000 loan classification according to banks' sel[-assessment; in trillions of yen )

\begin{tabular}{|c|c|c|c|c|c|c|c|c|c|}
\hline & \multirow{2}{*}{$\begin{array}{l}\text { Loan } \\
\text { amount }\end{array}$} & \multicolumn{2}{|c|}{ Scenario I } & \multicolumn{2}{|c|}{ Scenario II } & \multicolumn{2}{|c|}{ Scenario III } & \multicolumn{2}{|c|}{ Scenario IV } \\
\hline & & Loss ratio $1 /$ & Loss & Loss ratio 1/ & Loss & Loss ralio $1 /$ & $\overline{\text { Loss }}$ & Loss ratio $1 /$ & $\overline{\text { Loss }}$ \\
\hline Normal loans & 410.1 & $0.5 \%$ & 1.9 & $1.0 \%$ & 4.1 & $1.5 \%$ & 6.2 & $2.0 \%$ & 8.2 \\
\hline \multicolumn{10}{|l|}{ Loans to at-risk borrowers secured } \\
\hline by superiot collateral $2 /$ & 47.4 & $1.0 \%$ & 0.5 & $2.0 \%$ & 0.9 & $3.0 \%$ & 1.4 & $4.0 \%$ & 1.9 \\
\hline \multicolumn{10}{|c|}{ Loans secured by ordinary collateral } \\
\hline Borrowers requiring atlention & 50.5 & $10.0 \%$ & 5.1 & $17.5 \%$ & 8.8 & $25,0 \%$ & 12.6 & $35.0 \%$ & 17.7 \\
\hline Bankrupt borrowers 3/ & 10.5 & $20.0 \%$ & 2.1 & $30.0 \%$ & 3.2 & $45.0 \%$ & 4.7 & $60.0 \%$ & 6.3 \\
\hline \multicolumn{10}{|l|}{ Loans to bankrupt borrowers with } \\
\hline doubtful recovery value 3 / & 2.7 & $80.0 \%$ & 2.2 & $85.0 \%$ & 2.3 & $90.0 \%$ & 2.4 & $100.0 \%$ & 2.7 \\
\hline \multicolumn{10}{|l|}{ Unrecoverable loans to bankrupt } \\
\hline borrowers $3 /$ & 0.01 & $100.0 \%$ & 0.01 & $100.0 \%$ & 0.01 & $100.0 \%$ & 0.01 & $100.0 \%$ & 0.01 \\
\hline Total & 521.2 & ... & 11.7 & $\ldots$ & 19.4 & $\ldots$ & 27.4 & $\ldots$ & 36.8 \\
\hline Uncovered loan losses 4/ & $\ldots$ & $\ldots$ & 0.0 & $\ldots$ & 7.7 & $\ldots$ & 15.7 & $\ldots$ & 25.1 \\
\hline
\end{tabular}

Sources: Financial Services Ageney; staff calculations.

1/ Mechanical loss assumptions are used for the purpose of the simulation.

2/Collateral refers to both loan collateral and loan guarantees.

$3 /$ Bankrupt borrowers include de facto bankrupt borrowers and borrowers in danger in bankruptcy.

4/ Banks are assumed to hold a combined Y11.7 trillion in general and specific provisions. 
capitalized, notwithstanding some success in raising additional capital in FY2000, analysts estimate that their combined loan loss exposure exceeds their Tier-1 capital. The same conclusion has been reached for credit cooperatives and some of the other small financial institutions, which generally have the lowest capital ratios and are particularly exposed to the small and medium-sized enterprises that are experiencing widespread bankruptcies.

\section{Analysts also have concerns about the} low quality of major banks' capital. Following a decade of low profitability and two rounds of public capital injections, more than half of banks' Tier- 1 capital consists of deferred tax assets, public capital, and preferred equity instruments. Accordingly, shareholder equity is relatively small, particularly in contrast to banks' large exposure to market risk from their equity and JGB portfolios (see below). Moreover, deferred tax assets will expire unless they are claimed against profits over the next five years; banks will eventually want to repay injections of public capital; and preferred instruments will need to be rolled over in the course of the next two years.

\begin{tabular}{|c|c|c|}
\hline \multicolumn{3}{|c|}{ Major Banks' Regulatory Capital (Sept. 2000) } \\
\hline & $¥$ trm & Percent $^{1}$ \\
\hline Total regulatory capital & 41.3 & 11.6 \\
\hline Tier I capital & 22,8 & 6.4 \\
\hline Deferred taxes & 5.5 & 1.5 \\
\hline Public capital (pref. stocks) & 6.2 & 1.7 \\
\hline Other preferred stocks & 0.9 & 0.3 \\
\hline Other & 10.2 & 2.9 \\
\hline Tier II capital & 18.8 & 5.3 \\
\hline Public capital (sub. debt) & 2.5 & 0.7 \\
\hline \multicolumn{3}{|l|}{ Memorandim items: } \\
\hline Regional banks (Tier I) & 12.1 & 10.3 \\
\hline Regional banks (Tier II) & 3.0 & 8.2 \\
\hline Shinkin banks (Credit unions) & 5.8 & 9.8 \\
\hline Credit Cooperatives & 1.0 & 7.6 \\
\hline $\begin{array}{l}\text { Source: FSA. } \\
\text { ' Percent of tisk-weighted asset }\end{array}$ & & \\
\hline
\end{tabular}

\section{Banks will therefore need to substantially raise profitability over the medium} term to deal with the bad loan problem and strengthen their capital base. However, there are as yet few signs that profits will increase substantially in the near future. Major banks" operating profits in FY2000 were essentially unchanged compared to the year before, as sluggish credit demand continued to erode the average gross lending margin (Figure IV.1). Some banks have recently begun to shift toward fee-based activities such as domestic syndicated lending and investment banking, but these operations are still small and therefore unlikely to generate substantial revenues in the near term, especially in the face of strong competition from established market participants. Banks have also returned to the international loan market in search of higher margins, but this expansion comes at a time when other banks are tightening exposure in anticipation of rising credit risk. Finally, implementation of merger plans is proceeding slowly. Significant synergy gains have yet to be realized, and cost-cutting efforts have so far had only a small impact on operating profits. Partly reflecting market pessimism about bank restructuring, major bank share prices have declined by about 30-40 percent since merger plans were announced in August 1999 (Figure IV.2).

\section{High Exposure to Equity and JGB Markets}

\section{Bank exposure to market risk has increased as falling stock prices eroded banks"}

hidden capital gains in 2000 . The book value of shares and government bonds held by banks amounts to some $¥ 38$ trillion and $¥ 44$ trillion respectively for the major banks and $¥ 8$ trillion and $¥ 20$ trillion for the regional banks. In March 2000 , with the Topix at 1650 , major banks reported hidden reserves worth $¥ 8.1$ trillion, but these gains - which had been 
Figure IV.1, Japan: Major Banks' Profits, FY1990-2000

(In trillions of yen)

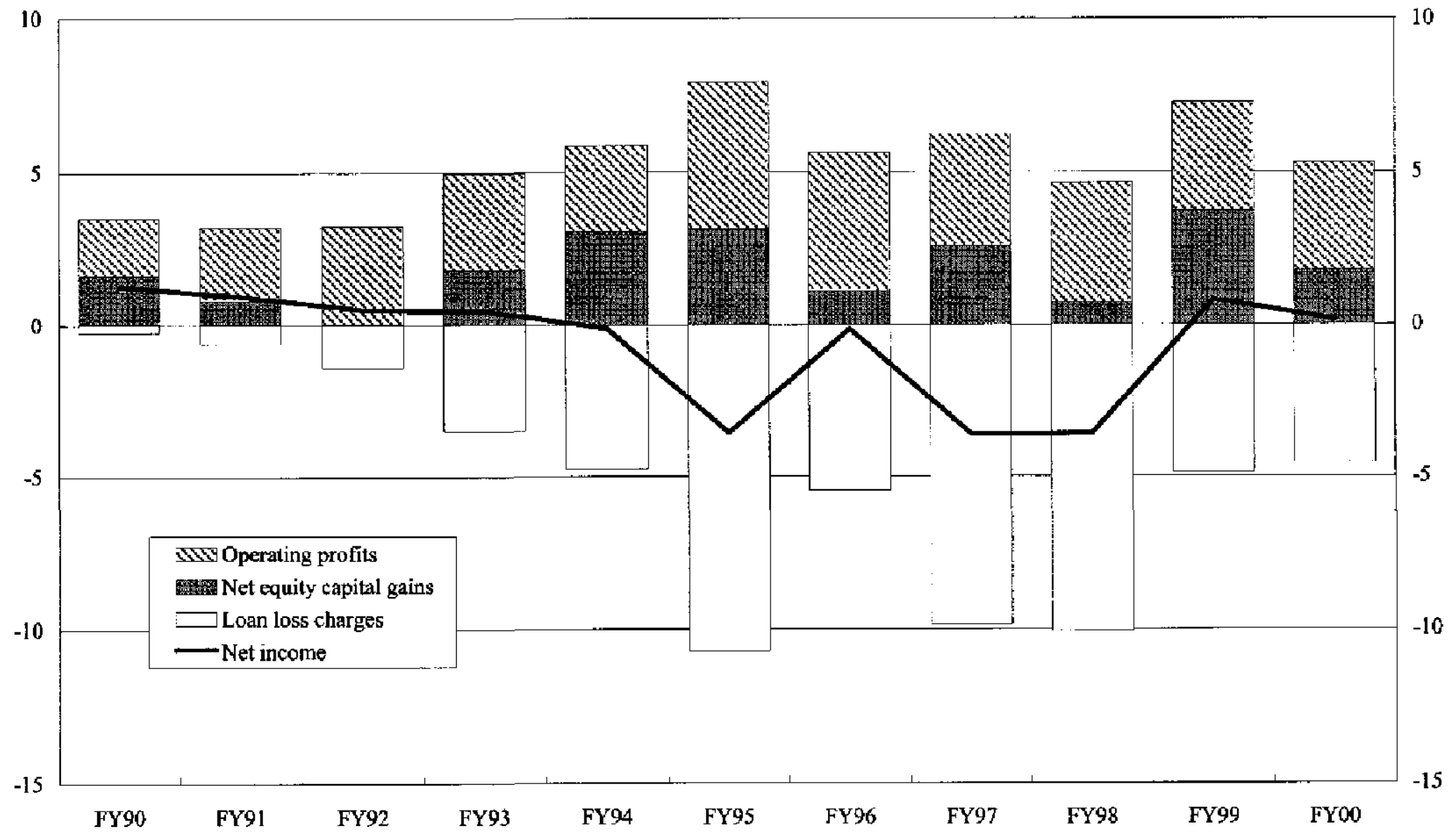

Source: FitchIBCA. 
Figure IV.2. Japan: Banking Indicators
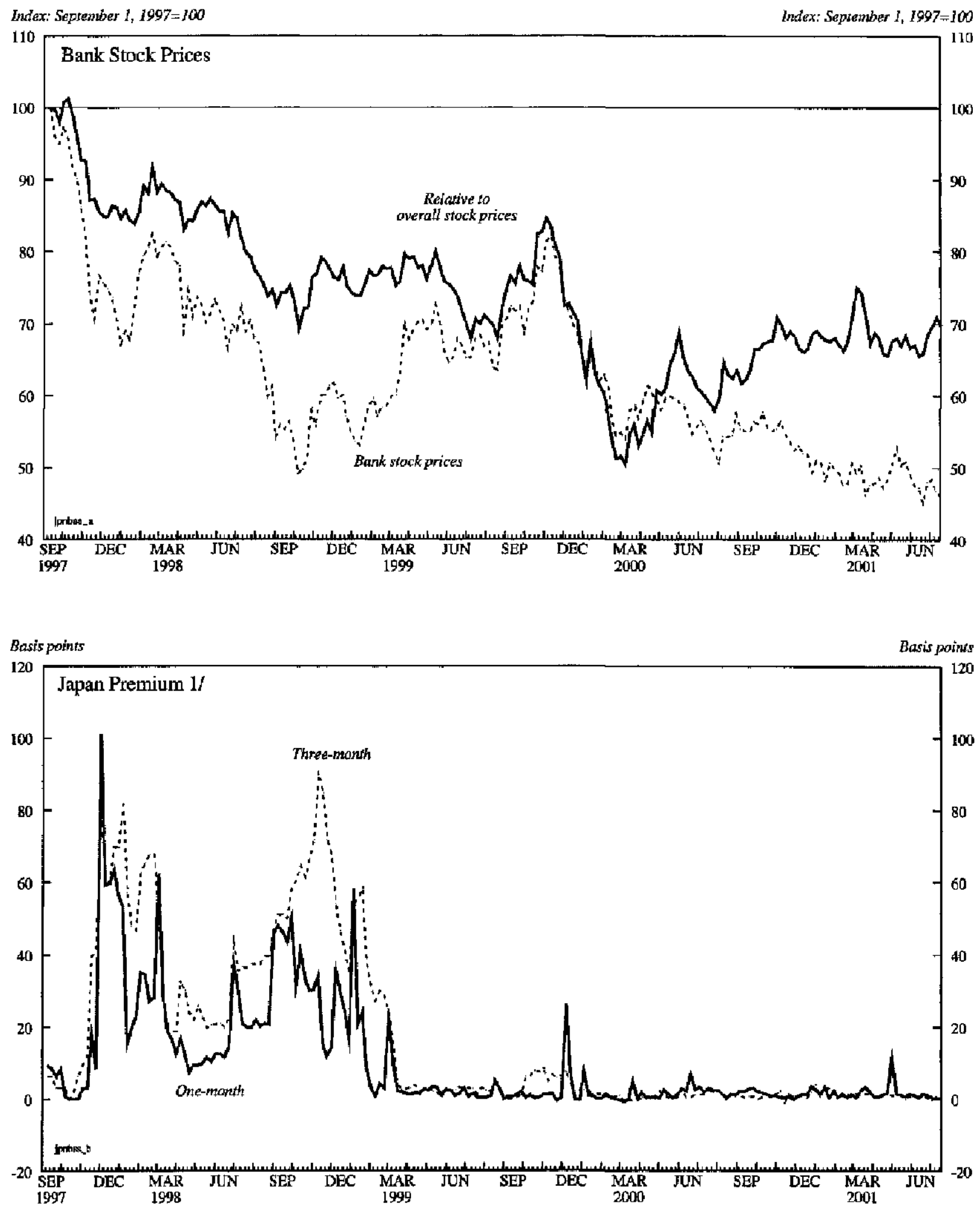

Sources: WEFA; and Blcomberg FInanclal Markets, L.P.

1/ Average U.S. dollar LIEOR of Fuji Bank, Bank of Takyo, and Norinchukln bank minus the LIBOR lix. 
used in the past to finance bad loan write-offs-evaporated during the year as the Topix slid below $1300 .{ }^{9}$ The drop in stock prices was short of what would have caused systemic problems, although concerns arose about the degree of losses at some individual banks at around the time that the equity market reached its trough.

14. Banks are also increasingly exposed to a sharp rise in JGB yields. In the absence of attractive lending opportunities, banks have continued to invest surplus funds in JGBs. By mid-2001, the share of government securities in bank assets increased to a record 10 percent, compared to around 4 percent at end-1998. During the year, bond holdings gained in value as 10-year JGB yields fell to low levels, but by the same token, JGB holdings became both less profitable and more risky. A 100 basis point rise in JGB yields is estimated to reduce major banks’ capital by about $¥ 1$ trillion, or 5 percent of Tier-1 capital (based on an assumed average duration of banks' JGB holdings of about 2 years). The FSA views this exposure as manageable, however and does not consider banks' interest rate exposure to be a source of significant risk.

\section{B. Policies to Strengthen the Banking System}

\section{The Government's Emergency Package}

15. In April 2001, faced with deteriorating confidence in the economy and the financial system, the government announced a package of measures to deal with the related problems of bad loans and corporate debt overhang and to reduce banks' substantial exposure to equity market risk. Further details of the package emerged in the context of the Council on Economic and Fiscal Policy's blueprint for economic reform, which was released in June 2001. The package contains two major initiatives:

- Bad loan disposal. The plan calls for the major banks to eliminate two categories of NPLs-loans to bankrupt and nearly-bankrupt companies, although not loans to borrowers requiring special attention-from their balance sheets over a two-year period. ${ }^{10}$ While banks can sell NPLs in their entirety or resolve bad loans through the courts, the package emphasizes the principle of fostering corporate reorganization through informal debt workouts along the lines of the London Approach, implying the use of debt forgiveness and debt-equity swaps. ${ }^{11}$ To this end, a private sector

\footnotetext{
${ }^{9}$ Some private sector analysts estimate that banks accumulate losses on their equity portfolio once the Topix slides below 1,270 points, with every 100 point change translating into a capital gain or loss of about $¥ 21 / 2$ trillion. The FSA considers the effect of changes in the Topix to be about two thirds of that amount.

${ }^{10}$ New NPLs would have to be written off within three years from the date they are classified as nonperforming. According to the FSA, while the plan focuses on the major banks, their efforts to remove bad loans from their balance sheets will inevitably require regional banks to do the same.

${ }^{11}$ The London Approach brings major creditors and other parties together on an informal basis to reach a collective decision on the feasibility of a corporate debt workout and on how
} 
committee recently issued an interim report on voluntary debt workouts, which require a restructured company to return to profitability within three years and clarify the responsibility of both shareholders and company management. Any loans that remain on banks' balance sheets after the specified period would be sold to the Resolution and Collection Corporation (RCC), which is to play a more active role in bad loan disposal, including through stepped-up securitization and active participation in debt workouts.

- Reduction in equity risk exposure. To reduce banks' exposure to market risk, bank stock holdings are to be limited to 100 percent of capital (to be defined as either shareholder equity or Tier-1 capital) from 2004 onwards. A Bank Shareholding Acquisition Corporation (BASAC) is to be established to facilitate scaling down cross-shareholdings. ${ }^{12}$ The BASAC would purchase stocks over a perriod of 5 years, with the aim of unwinding its holdings through sales to the public (e.g., in the form of exchange-traded or mutual funds) or repurchases by the issuing companies over the following 5 -year period. The government will initially guarantee up to $¥ 2$ trillion of funds for share purchases. Any loss of the BASAC at its dissolution would be covered in the first instance by the contributions of its member banks, which will cansist of an aggregate $¥ 10$ billion in initial contributions, plus subordinated contributions equivalent to 8 percent of their sales to the BASAC (effectively a haircut that would be returned if the BASAC returned sufficient profits). The government would cover the remaining loss. Share sales by banks to the BASAC will be voluntary and are to take place at market prices. Relevant legislation is likely to be introduced during the extraordinary Diet session in the autumn of 2001, and the corporation would take up operations early in 2002.

16. Although market analysts generally welcomed the authorities' willingness to focus on the corporate debt-bad loan nexus, they raised a number of concerns. First, the package only focuses on the major banks, which account for less than half of the banking system's total assets and problem loans and have stronger asset quality and capitalization than the regional banks. Second, the plan does not address the need for more forward-looking provisioning practices, or call for more aggressive treatment of the large stock of "gray zone" loans whose repayment prospects are also very uncertain. Third, it will be important that corporate restructuring plans submitted in exchange for tax-subsidized debt forgiveness are realistic and provide a sufficient basis for a sustained tumaround in corporate profits.

to share the related losses. The role of the authorities would largely be that of resolving coordination problems as an honest broker.

${ }^{12}$ Banks hold shares worth an estimated 130-150 percent of bank capital. A target exposure of 100 percent of capital implies that banks would have to sell $¥ 10-15$ trillion in shares. 
17. Market participants have also raised concerns about the equity purchase scheme. The scheme has the potential to weaken much-needed market discipline on both banks and corporations, particularly if it comes to be seen as effectively putting a floor under stock prices. At the same time, it allows banks to maintain an equity exposure equivalent to 100 percent of capital-leaving open the possibility that another scheme may be needed in the future. There are also concerns that, by setting a precedent, the plan could lead to other asset-purchasing schemes (for example, to reduce banks' JGB exposures). Finally, the plan was seen as giving banks too much discretion in choosing the stocks they sell to the scheme, raising the risk that banks could unload the stocks of fundamentally unsound companies on the BASAC—stocks that the BASAC might find impossible to resell later.

\section{Progress In Strengthening the Supervisory and Regulatory Framework}

18. Following the first round of on-site inspections of major and regional banks during 1998/99, which focused primarily on asset quality, a second inspection round currently underway concentrates on banks' risk management systems. It examines the valuation and soundness of financial assets, exposure limits to various types of market risk, and internal monitoring and controls (including in preparation for the introduction of the revised Basel capital adequacy standards). The FSA has released a revised inspection manual for banks, focusing on improved audit functions and including changes made necessary by the transition to mark-to-market accounting. Meanwhile, the first round of inspections of nearly 300 credit cooperatives that began in April 2000 after supervisory authority was transferred from regional governments to the FSA will have been completed by mid- 2001 . The FSA's longer-term supervisory priorities include decreasing the time between bank inspections from 2-3 years to one year, and pushing for quarterly instead of semi-annual disclosure of banks' investment results, with the aim to eventually compile quarterly earnings results.

\section{The authorities have reaffirmed their commitment to re-introduce partial} deposit insurance in April 2002, although liquid deposits - mainly current deposits-will be fully covered until April 2003. ${ }^{13}$ Under the new deposit insurance law, which initially was to come into force in FY2001 but was delayed by concerns over the health of the credit cooperative sector, the scope of institutions and types of deposits covered will be widened to include certain bank debentures, interest on deposits, and deposits of public entities. At the same time, to minimize the cost of future bank failures, the new legislation provides for stronger instruments to close troubled institutions and sell the viable parts to an assuming bank. For example, measures have been taken to facilitate the swift transfer of business (ideally over the course of a weekend), including the requirement to maintain adequate information on depositors and loan transactions. In addition, the scope of financial assistance to be provided to the assuming institution has been enlarged, providing (among other things) for the Deposit Insurance Corporation (DIC) to share losses that are incurred from loans transferred from a failed institution.

${ }^{13}$ The new deposit insurance framework would cover $¥ 10$ million per depositor plus interest. 


\section{Changes in the Public Support Framework}

20. Public funds have been used in a number of costly bank failures in recent years (Table IV.4). Costs of covering the failure of several financial institutions in the late 1990s amounted to some $¥ 81 / 2$ trillion ( $1 \frac{3 / 4}{4}$ percent of GDP). The disposal of a large number of failed shinkin banks (credit unions) and credit cooperatives conducted in FY2000 cost the government about $¥ 800$ billion. Another $¥ 17$ trillion, which has been used for capital injections and loans to nationalized banks, is expected eventually to be repaid. Taken together, public funds used to address the banking crisis up to this point amount to some 5 percent of GDP, toward the upper end of the range for other industrial countries that have experienced banking crises. ${ }^{14}$

21. In view of the extension of blanket deposit insurance by one more year, cutbacks in the public support framework for the banking sector have also been pushed back until April 2002. Changes in the composition of the framework have raised questions about the government's ability to facilitate future bank restructuring with public capital. During FY2001, funding for the government’s safety net is to remain unchanged at $¥ 70$ trillion, but the accounts for capital injections and bridge bank financing will be considerably reduced and can only be used to address problems in the credit-cooperative sector before they are phased out in 2002. ${ }^{15}$ Under the revised deposit insurance law, a new emergency account provides $¥ 15$ trillion to ensure the stability of the financial system in case of a systemic threat (including at the regional level). These funds are available for capital injections, full coverage of deposits, and temporary nationalization in the event of financial instability, although the circumstances under which they could be used have been left vague. The systemic clause, which only the Prime Minister can invoke, appears more restrictive than the Early Strengthening Law that expired in March 2001 (the latter allowed the use of public funds to prevent a credit crunch and promote write-offs of problem loans\}. This may have weakened an important tool for the government to enable banks to address their bad loan problems more aggressively, and the projected decline in available public funds after FY2002 raises more general concerns about the adequacy of public support for bank restructuring in the absence of a systemic crisis.

\footnotetext{
${ }^{14}$ By comparison, the public costs of the U.S. savings and loan crisis amounted to 2.5 percent of GDP.

${ }^{15}$ The current spending limit of $¥ 6$ trillion in the DIC’s General Account-which is partly funded through insurance premia--will be maintained after March 2002.
} 
Table IV .4. Bank Support Framework

\begin{tabular}{|c|c|c|c|c|c|c|}
\hline \multirow{2}{*}{ Account } & \multirow{2}{*}{ Purpose } & \multicolumn{4}{|c|}{ Ptoposed Limits (in trillions of yen) } & \multirow{2}{*}{$\begin{array}{l}\text { Used by } \\
\text { March } \\
2001^{1,2}\end{array}$} \\
\hline & & FY99 & FY00 & FY01 & $\mathrm{FY02}$ & \\
\hline General Account & $\begin{array}{l}\text { Depositor ptotection (partly } \\
\text { premium-funded) }\end{array}$ & 2 & 4 & 6 & 6 & \multirow{2}{*}{$12 \frac{1}{2}$} \\
\hline Special Accolunt ${ }^{3}$ & $\begin{array}{l}\text { Depositor protection (public } \\
\text { loans and grants) }\end{array}$ & $\begin{array}{c}17 \\
(10+7)\end{array}$ & $\begin{array}{c}23 \\
(10+13)\end{array}$ & $\begin{array}{c}23 \\
(10+13)\end{array}$ & - & \\
\hline $\begin{array}{l}\text { Financial Revitalization } \\
\text { Account }\end{array}$ & $\begin{array}{l}\text { Lending to nationalized and } \\
\text { bridge banks }\end{array}$ & 18 & 18 & 10 & -- & 5 \\
\hline $\begin{array}{l}\text { Financial Functioning Early } \\
\text { Strengthening Account }^{3}\end{array}$ & Capital injections & 25 & 25 & 16 & -- & 8 \\
\hline $\begin{array}{l}\text { Crisis Management } \\
\text { Account }\end{array}$ & $\begin{array}{l}\text { Emergency measures for } \\
\text { major and regional banks }\end{array}$ & -- & -- & 15 & 15 & -- \\
\hline Total & & 62 & 70 & 70 & 21 & $251 / 2$ \\
\hline
\end{tabular}

Source: Deposit Insutance Corporation; and staff estimates.

'Staff estimate

${ }^{2}$ Most of the funds are expected to be recovered, except for $¥ 81 / 2$ trillion in government grants to cover depositor losses.

${ }^{3}$ Established under the Financial Functioning Early Strengthening Law in 1998.

\section{Restructuring in the Banking and Insurance Sector}

\section{Failures, Mergers and Strategic Alliances}

22. Most of the banks that failed and were nationalized since 1998 have been reprivatized. In March 2000, LTCB was sold to a private consortium led by foreign investors, and in September 2000, ownership of NCB was transferred to a domestic consortium. Both banks were cleared of most of their bad assets, received public capital injections, and submitted ambitious restructuring plans to the government, including commitments to maintain strong capital adequacy ratios. In August 2000, the first of five regional banks that failed in 1999 was transferred to a new owner. Purchasing agreements have been completed for the remaining four, including with two foreign investors, and the process of reprivatizing them is expected to be essentially complete by mid-FY2001.

23. The reorganization of Japan's banking system advanced in April 2001, when the remaining three of the four major banking conglomerates took up combined operations. Following the example of Mizuho- a bank holding company that united three of the largest banks under one roof in October 2000- two organizations (UFJ and Mitsubishi Tokyo) have also opted for a holding structure, while Sumitomo and Sakura Bank underwent a full-scale merger. ${ }^{16}$ Restructuring plans for the new institutions have generally been strengthened, ineluding through the announcements of further personnel cuts over the medium term, but the full integration of computer systems is not expected to be achieved

\footnotetext{
${ }^{16}$ Sanwa Bank and Tokai Bank are slated to merge in early 2002, and Mizuho plans to reorganize its operations into two subsidiaries, dealing separately with corporate and retail customers.
} 
before 2003 in most cases. The completion of the Big Bang reforms prompted greater cooperation between banks and trust banks, some of which have joined one of the major alliances, and between banks and insurance companies (see below). The lack of a strong retail network has also led major banks to cooperate more closely with regional banks, and some banks have begun to work with the postal savings system to improve access to banking services through ATMs in post offices and other avenues.

24. Restructuring among regional banks also picked up during FY2000, mainly in the context of a number of mergers and cooperation agreements, and core profitability has been boosted by expenditure reductions and an improvement in the net interest spread. Moreover, banks have generally managed to strengthen their customer bases. Many banks replenished capital, decreasing the number of banks with capital adequacy ratios below 8 percent from 31 to 25 in the six months to September $2000 .{ }^{17}$ Six more banks applied for public capital injections before the deadline expired at end of FY2000. On the credit cooperative side, the number of institutions declined from 373 to 291 in the five years ending March 2000. A total of 53 credit cooperatives failed, one was liquidated, and 28 were absorbed by mergers. The process of consolidation picked up steam as the FSA completed its first round of inspections in FY2000 (credit cooperatives had previously been supervised by local governments). The FSA closed a total of 12 institutions during the fiscal year and more failures are widely expected.

\section{New Entrants to the Banking Sector}

25. Competition in the banking system is intensifying as domestic nonfinancial competitors make inroads, armed with new business models such as banking through retail outlets or internet banking. The demand for such services has required changes to the regulatory framework, particularly in view of concerns that the new banks might be excessively vulnerable if their nonbank parent companies experience financial difficulties. To address these concerns, in March 2001 the FSA submitted legislation that would require FSA approval for nonbanks to hold more than a 5 percent stake in a bank. Shareholders with a stake exceeding 20 percent, or otherwise having strong influence on the bank, could be subject to financial inspections if questions regarding the sound management of the bank emerged. A majority shareholder could be asked to shoulder the losses of its banking subsidiary if the subsidiary experienced financial difficulties. Moreover, regulations will be in place to ensure the operational independence of banks from major stakeholders, to subject the sharing of customer information between banks and parent companies to operational safeguards, and to probibit banks from bailing out parent firms and other affiliates.

\section{The new legislation is to replace existing FSA guidelines by the end of FY2001 at} the latest. The opening of the sector to new entrants paved the way for the re-privatized NCB to start business (one principal shareholder is a nonfinancial company) and has led to applications for several new banking licenses, most of which have already been granted. By mid-2001, four new banks have started operations that use the Internet as a main channel for

${ }^{17}$ Banks that are not internationally active face a 4 percent minimum capital requirement. 
the delivery of financial services or use convenience-store ATMs to deliver services to customers.

\section{The Life Insurance Sector}

27. Policy cancellations and sluggish sales at life insurance companjes continued to depress premium income during FY2000, magnifying the longstanding problem of negative yield spreads. ${ }^{18}$ Insurers were also affected by declining stock prices, which reduced latent profits on their sizable equity holdings, and by deteriorating loan quality. As a result, solvency margin ratios for the major 7 life insurers, while still on average about triple the mandated 200 percent minimum, have declined by about 180 percentage points during FY2000. ${ }^{19}$

\section{Combined with an adverse economic environment, these difficulties contributed} to several failures among mid-size life insurers over the past year, bringing to seven the number of institutions that have failed since 1997. Three companies filed for bankruptcy under the modified Law on Special Reorganization Procedures for Financial Institutions passed in mid-2000 that provides for quick restructuring under court protection, including through a possible cut in guaranteed yields. All of the failed companies have in the meantime concluded purchasing agreements with sponsoring institutions and have resumed operations under their new parents. The resolution of some cases required assistance from the Life Insurance Policyholders Protection Corporation, whose initial $¥ 960$ billion in funds have now declined to $¥ 420$ billion-an amount approximately equivalent to previous government injections.

\section{The government has taken a number of measures to improve supervision of life} insurers. Life insurers have undergone one round of FSA inspections, focusing partly on loan quality, and an inspection manual for the insurance sector was finalized in the summer of 2000 . From April 2001, the formula to calculate the solvency margin has been changed to include the risks from investment in unlisted shares, domestic bonds and foreign securities, evaluated at market prices. Although the change is expected to lower margins by about $50-200$ percentage points, the remaining insurers would remain well above the 200 percent mark that would trigger FSA intervention. The FSA has also required insurance companies to publish more financial information, including core profits from insurance business, twice a year (disclosure of interim results is currently voluntary). Moreover, in a recently released interim report, the Financial System Council (FSC) suggested steps to make it easier for companies to build capital, including through a revision of the requirement to pay out at least 80 percent of annual profits as dividends to policyholders. The FSC also proposed to allow insurance companies to reduce guaranteed returns on insurance policies outside a formal

\footnotetext{
${ }^{18}$ The yield spread is the gap between guaranteed rates of return on policies and returns on assets.

${ }^{19}$ The solvency margin measures an insurance company's ability to maintain payments to policyholders against exposure to different categories of risk.
} 
restructuring process (a right that was suspended in 1996), provided policyholders participated in the decision-making process.

30. Foreign insurers have used recent failures of life insurance companies as an opportunity to gain a stronger foothold in the Japanese market. Five of the seven companies that failed have been taken over by major foreign companies, and three smaller insurance companies have also come under foreign control. Domestic insurance companies have responded to increased competition by forging a web of alliances and mergers in an attempt to solidify their financial bases before a wider opening of the insurance market to banks and foreign companies occurs. ${ }^{20}$ Domestic companies will also have an opportunity to branch into "third sector" products that include relatively new products such as medical care and cancer insurance and that so far have been largely reserved to foreign competitors. Mergers have mostly been concentrated in nonlife insurance (which will be particularly affected by the opening of the third sector), but life insurers have also begun to build alliances with nonlife companies. The benefits of cross-sectoral cooperation are mutual, combining the stronger financial positions of nonlife companies with broader sales networks of life insurers.

\section{Remaining Challenges}

\section{Looking ahead, a key challenge for the authorities is to restore the financial} health of the banking system, in particular through a speedy resolution of the bad loan problem. An important task will be the continued strengthening of loan classification and provisioning practices, which could result in the downgrading of gray zone loans. Moreover, the new initiative to accelerate bad loan disposal should be pursued rigorously, with efforts to include regional banks and credit cooperatives in the process. In view of the possibly sizable losses that could result from higher write-offs, further targeted public capital injections may be needed to recapitalize banks with viable business franchises to prevent a credit crunch and maintain systemic confidence. To limit moral hazard, such injections would need to carry appropriate conditionality, including performance criteria that ensure banks' active participation in debt workout agreements, and a credible threat to convert preferred into ordinary shares in case of noncompliance. ${ }^{21}$

32. Now that a legal and institutional framework for corporate debt restructuring is largely in place, the authorities need to provide incentives that force both creditors and borrowers to use the tools that have been provided. While regulatory pressure and performance targets for recapitalized banks could provide a push for debt workouts from the lending side, substantive deregulation of the weaker sectors of the economy would expose

\footnotetext{
${ }^{20}$ The consolidation of insurance companies has so far occurred largely along the lines of the four major banking groups, likely heralding a shift toward greater integration of banking and insurance services following the completion of the Big Bang reforms.

21 The FSA has emphasized its view that, in order to limit moral hazard, decisions to inject public funds should be based on true need and limited to systemically important cases.
} 
bank borrowers to stronger market forces and bolster incentives for workouts from the borrowing side. Once implemented, recent proposals by the Council on Economic and Fiscal Policy and in the draft guidelines for debt workouts could add further support to a marketdriven resolution of the bad loan problem, for example by requiring that independent experts assess whether informal workout arrangements are adequate to restore financial viability. In addition, planned measures to liquefy the secondary market for bad loans, including by liberalizing the real estate market and providing for a more active role of the RCC could be crucial in helping banks to dispose of bad assets (for example, through securitization).

33. Finally, the opening of the financial sector to new entrants, both in the banking and insurance industries, should lead to greater competition and a general improvement in the provision of financial services. The government would have two crucial roles to play. First, financial intermediation would benefit from a gradual reduction in the role of government financial institutions, including the postal savings system, which is indeed now under active consideration under the new government's 7-point plan. Second, the government would need to have a strategy in place that would ensure the timely exit of unviable institutions from the market. 


\section{Structural Reform ${ }^{1}$}

\section{A. Strategic Framework ${ }^{2}$}

1. The new government has provided fresh momentum to the structural reform process. Since the early 1990 s, successive administrations have continued to implement structural changes with varying speed. The recent blueprint announced by the Koizumi government indicates a greater determination to address some deep-seated problems that are at the heart of the economy's weak performance in recent years. In addition to implementing the April emergency package on bank and corporate restructuring formulated by its predecessor, the government has incicated it will focus its reform efforts on a number of key areas, including privatization of public enterprises, regulatory reform, and fiscal reform. While the details remain to be fully fleshed out, a recent report by the Council on Economic and Fiscal Policy (CEFP) has provided a blueprint for the government's strategy to revitalize the Japanese economy. ${ }^{3}$

2. While characterizing the resolution of the NPL problem as the first essential step for Japan's revitalization, the CEFP's blueprint focuses on deep structural reforms to promote competition and enhance the role of market forces. The Seven Point Plan-... "Structural Reform of the Japanese Economy: Basic Policies for Macroeconomic Management" approved by the Cabinet on June 26-is wide-ranging, placing particular emphasis on structural reform to rejuvenate the economy among other issues (Box V.1).

- Emphasis will be given to deregulation and competition policy to advance the role of market forces. Business opportunities will be opened to the private sector through the privatization of public enterprises, possibly including the services of the post office, and further use of private finance initiatives (PFIs). ${ }^{4}$ The tax system will be reviewed to support businesses, with such a review likely to include the introduction of consolidated taxation. Economic laws such as the Commercial Code

${ }^{I}$ Prepared by Takashi Nagaoka (ext. 37613).

${ }^{2}$ Reforms in fiscal and financial areas have been covered in earlier chapters.

${ }^{3}$ The CEFP was established in the context of the central government reorganization in January 2001. Under the leadership of the Prime Minister, the Council develops a broad agenda for short- and medium-term economic and fiscal policies and reform initiatives which will be the basis for the annual budget formulation.

${ }^{4}$ PFIs involve the private sector in building, managing and maintaining public facilities, such as roads, ports, and sewage. The private sector finances the operation, and collects payments from users or the public sector over time. Increased use of PFIs is expected to reduce the overall public works spending by the government, and increase efficiency and risk sharing through private sector involvement. 


\section{Box V.1. Blueprint for the Structural Reform of the Japanese Economy}

A blueprint for Japan's structural reform was approved by the Cabinet on June 26, 2001. The blueprint-"Structural Reform of the Japanese Economy: Basic Policies for Macroeconomic Management" - recognized the importance of full-fledged structural reforms across sectors for revitalizing Japan's economy. It characterized the resolution of the NPL problem as the first essential step, and identified seven forward-looking reform programs.

- Privatization and regulatory reform: To expand business opportunities for the private sector, the program plans to promote the privatization of public and semi-public institutions, as well as conduct studies, including on privatization of postal, savings, and life insurance businesses of the post office, while expecting an increase in private finance initiatives. Market forces will be introduced to areas of health, nursing care, social welfare and education, which have so far lacked competition.

- Supporting challengers: To crcate a society that allows individuals to fulfill their potential, various measures (including in the area of taxation) will be taken to support business startups and encourage investments in capital markets rather than savings at banks. The Fair Trade Commission will be strengthened to foster competition, and wide-ranging regulatory reforms will be legislated to support the IT revolution.

- Strengthening welfare and insurance: To ensure security and stability in the future, social security numbers and Individual Social Security Accounts will be introduced to integrate social security services. A sustainable pension system and balanced pension taxation are to be sought in a comprehensive pension system reform. A Medical Services Efficiency-Boosting Program will be formulated to achieve efficient and high-quality medical care.

- Doubling knowledge stock: To enhance human capital development, educational support will be boosted through providing scholarships and education vouchers, while private sector donations for education and research will be encouraged including through tax concessions.

- Lifestyle revolution: To create an infrastructure to allow individuals to pursue their own lifestyle, impediments for female workers will be reduced through reforms in the fax and social security systems and by promoting the childcare service industry. Construction of "elderly-friendly" buildings will be expanded to enhance the welfare of the elderly.

- Local independence and revitalization: To cmpower local governments, the program plans to reorganize municipalities, and lessen national government involvement through a reduction in national subsidies and review of local grants and tax systems, coupled with an expansion of local taxation.

- Fiscal reform: To create a simple, efficient, government, fiscal reforms will be undertaken, including the review of earmarking of certain revenue sources, changes in the practice of budget allocations based on the distinction between public works and non-public works, and reprioritization of public works spending.

The blueprint also called for a complete reform of Japan's policy-making process. While it listed measures to reflect more directly the people's voice in the policy process (e.g., direct popular election of the Prime Minister, national dialogues through town meetings, etc.), it proposed a new budget compilation process led by the CEFP. Annual budgets are expected to reflect medium-term economic and fiscal plans based on a medium-term outlook. The FY2002 budget will initiate the reform process listed above, including by limiting new JGB issues to $¥ 30$ trillion. 
as well as the judiciary system will be overhauled so as to keep pace with the changing environment, while the Fair Trade Commission will be strengthened to promote fair competition. ${ }^{5}$ Securities market reform will include measures to attract individual investors, while real estate market reform will be led by the Urban Revitalization Headquarters' projects. ${ }^{6}$ Measures will be taken to enhance labor mobility, for example by creating an environment where gender and age do not limit opportunities.

- The plan also emphasizes other accompanying measures to promote economic growth. Focused investment in human capital will be made and promotion of science and technology will be prioritized, especially in the areas of information technology (IT), biotechnology, and nano-technology. Measures will be taken to activate the labor market by supporting retraining programs.

3. The blueprint anticipates 2-3 years of low economic growth before the results of reform measures set the base for higher growth. The CEFP estimates the economy would post growth of $0-1$ percent in the intensive reform period, while the estimates of additional unemployment from NPL disposals vary from 100,000-200,000 (by the CEFP) to 300,000500,000 (by the private sector) ${ }^{7}$ Estimates by private sector analysts, however, suggest that additional unemployment could exceed 1 million as a result of overall structural reforms. However, the authorities expect the economy to recover to around 2 percent growth once the problems are solved in a comprehensive manner, and about 5.3 million new jobs to eventually be created as the fruit of structural reform.

\section{B. Corporate Restructuring}

4. The government's moves to accelerate structural reform reflect the realization that, despite improvements in a number of key industries, the corporate sector as a

\footnotetext{
${ }^{5}$ While the blueprint did not give details, a large-scale revision of the Commercial Code is being contemplated to improve corporate governance, including through expanding the role of external board members, clearly separating executive and auditing functions, extending the use of stock options, and using IT for shareholders' meetings.
}

${ }^{6}$ The Urban Revitalization Headquarters was established to lead the initiatives on urban revitalization based on the emergency package of April 2001. Headed by the Prime Minister, it will promote urban revitalization programs aimed at constructing recycle-oriented urban structures and introducing other measures to enhance the efficient use of land.

${ }^{7}$ Assuming the labor force stays constant, estimates of the impact of NPL disposal by the CEFP and the private sector analysts imply an increase in the unemployment rate of about $0.1-0.3$ percentage points and $0.4-0.7$ percentage points, respectively, from 4.9 percent in May 2001. Meanwhile, private sector estimates of the impact of the overall structural reform agenda would imply a 1.5 percent increase in the unemployment rate. 
whole suffers from low profitability and high debt (Figure V.1). The ratios of companies' labor costs, fixed assets, and debt to sales show that the "three excesses," especially the latter two, still remained high in 2000 . Although a rising number of companies have announced major restructuring efforts, including through labor force reductions, these plans have not yet been implemented on a large scale. ${ }^{8}$ As a result, indicators continue to show a labor excess comparable to that in the mid-1990s, and capacity utilization rates have remained low. ${ }^{9}$ Meanwhile, the continued drop in the debt-to-equity ratio, which began in the latter half of the 1990s, suggests that companies have achieved some success in debt reduction, but the ratio still remains high. Behind these aggregate numbers, however, there have been major differences in the degree of excess labor, capital, and debt between some leading, mainly export-oriented, industries (especially in manufacturing, particularly electrical machineries) and lagging nonmanufacturing industries (especially, construction). ${ }^{10}$

5. Progress in corporate restructuring over the past year has been facilitated by a number of regulatory changes and other policy measures taken by previous administrations:

- Close to 100 restructuring plans have been approved under the Industrial Revitalization Law (IRL) since its enactment in October 1999. The law provides tax incentives (e.g., an extended period of loss carry-forward and accelerated depreciation for new investments) and financial support (e.g., loan guarantees and financing from public financial institutions) to firms with credible restructuring plans. While the required approval process, involving government ministries, has so far not been based on quantitative criteria, the provisions of the law are to be further tightened to include numerical criteria in line with proposals for the bad loan disposal framework in the April emergency package. ${ }^{11}$ The law expires at the end of FY2002.

\footnotetext{
${ }^{8}$ For example, many restructuring plans involve reduction of workforce mainly through orderly retirement and restricting new hires over multiple years.
}

${ }^{9}$ The vintage of the capital stock increased by $1 \frac{1 / 2}{2}$ years over the past decade to above 10 years.

${ }^{10}$ For example, while the debt to equity ratio for the whole industrial sector was above 290 percent in FY2000 (comparable to that in Germany, but higher than the 200 percent in the U.S.), it was below 95 percent for Sony and 135 percent for Toyota, and over 1,200 percent for general contractor Kajima Corporation (all from FY2000 annual reports).

${ }^{11}$ Numerical criteria are expected to include improvements in quantitative indicators such as ROE, ROA, and interest coverage ratio, and projected cash flows will need to be sufficient to eliminate excess debt within 10 years. 
Figure V.1. Japan: Selected Indicators of Business Conditions, 1980-2001
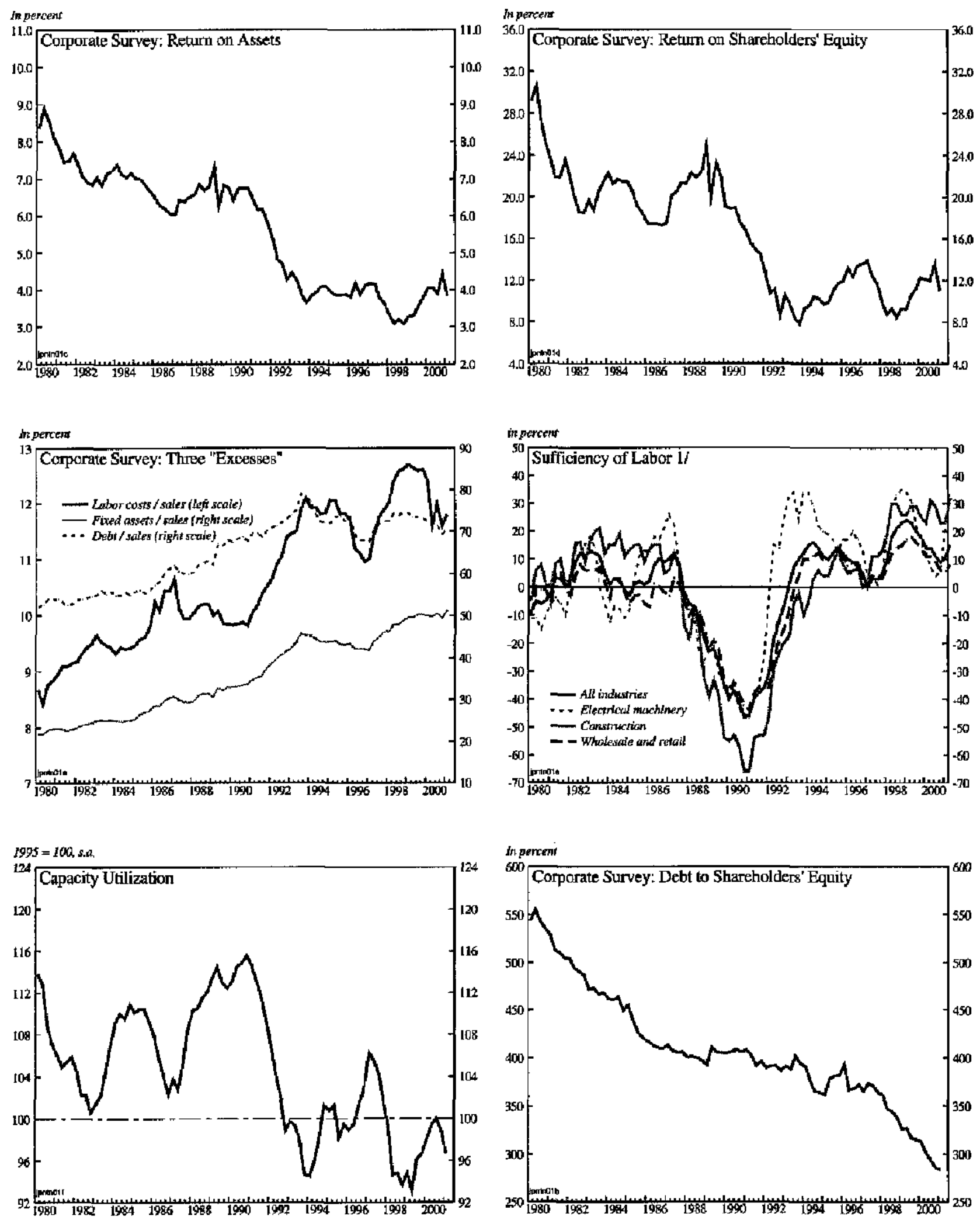

Sources: Nikkei Telecom: Benk of Japan; Ministry of Finance; and staft calculations.

1/ Peroent of excese minus parcent of inaufficiency. 
- The number of mergers and acquisitions (M\&As) has increased rapidly over the past year (Figure V.2). An increasing number of firms have been involved in M\&A activities to strengthen core businesses and for group restructuring purposes, and the participation of foreign firms has also expanded. ${ }^{12}$ Even large firms in mature industries - such as shipbuilding, chemicals, steel, and trading-are increasingly choosing this route for reorganization. The accumulation of experience by mediators and the improved transparency of corporate operations in the context of shifting to internationally accepted accounting standards--which makes it easier to value firms - both contributed to a 40 percent increase in cases in 2000 . Nevertheless, the ratio of M\&A values to total market capitalization (including the financial sector) has remained low at $3 \frac{1}{2}$ percent compared to $13 \frac{1 / 4}{4}$ and $201 / 2$ percent in the U.S. and EU, respectively. Moreover, M\&A activity involves almost exclusively "friendly" agreements rather than hostile takeovers. ${ }^{13}$

- The rate of bankruptcy has picked up in recent years, with an increasing share of corporate reorganizations under court supervision (Figure V.3). The total number of bankrupteies increased by more than 23 percent and the value by 77 percent in 2000, partly reflecting the introduction of the Civil Rehabilitation Law (CRL) in April 2000. This law allows easier access to legal procedures for debtor-in-possession reorganization (similar to Chapter 11 procedures in the U.S.). ${ }^{14}$ While the law initially targeted small and medium sized enterprises, large firms such as a retail giant Sogo also filed under the new law, attracted by the expedited process which on average takes only about six months from application to approval of the restructuring plan, compared to 12-14 months under earlier procedures. The number of bankruptcy filings under the CRL, reached 754 in FY2000, more than triple the average annual number of cases filed under its predecessor, the Composition Law (Wagi-hou), and the amount of debt involved amounted to $¥ 6.9$ trillion, or more than a quarter of the total debt held by failed firms. ${ }^{15}$ Nonetheless, the number of CRL filings in Japan is still much smaller than under Chapter 11 in the U.S.

\footnotetext{
${ }^{12}$ See Nomura Securities (2001). Excludes the financial sector. Cases aimed at pursuing intra-group restructuring and increasing the share in related firms' equities are counted under group restructuring purposes.

${ }^{13}$ The legal framework for takeover bids, introduced in 1971 , has been used mainly as a vehicle for friendly mergers, rather than hostile takeovers. A takeover of a Japanese pharmaceutical company by a German firm in early 2000 was reported to be the first such hostile takeover (aimed at actually taking control of the company rather than reselling the shares to other incumbent equity holders for capital gains), while another widely publicized case by a Japanese consultant company ultimately failed to take over the target firm.
}

${ }^{14}$ An overview of Japan's bankruptcy system and recent reform is provided in Levy (2000).

${ }^{15}$ See Teikoku Databank, Ltd. (April 2001). 
Figure V.2. Japan: Mergers and Acquisitions

Number of cases
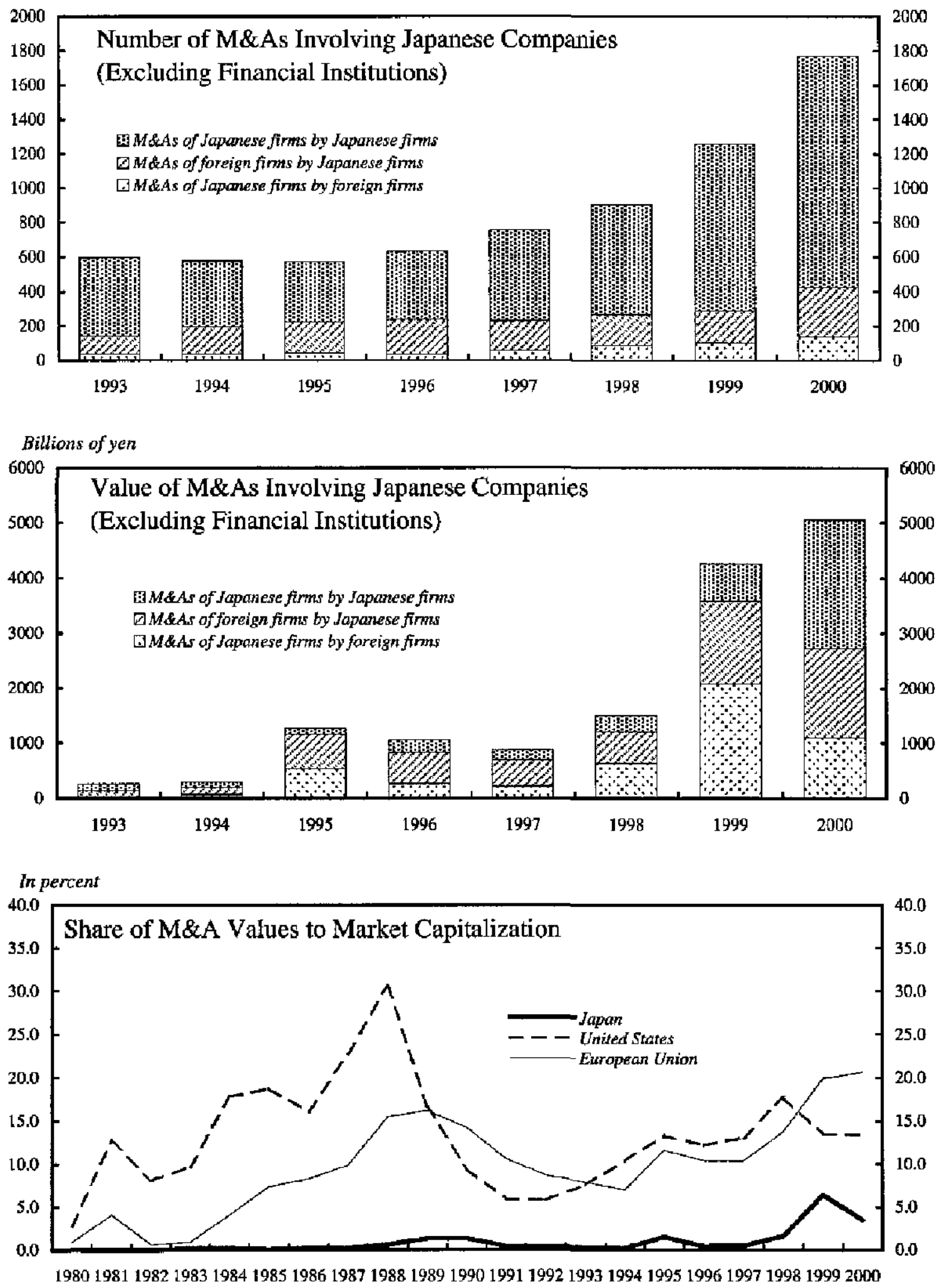

Sources: Nomura Securities Co., Ltd; and Merril Lynch Japan, Inc. 
Figure V.3. Japan: Bankruptcies
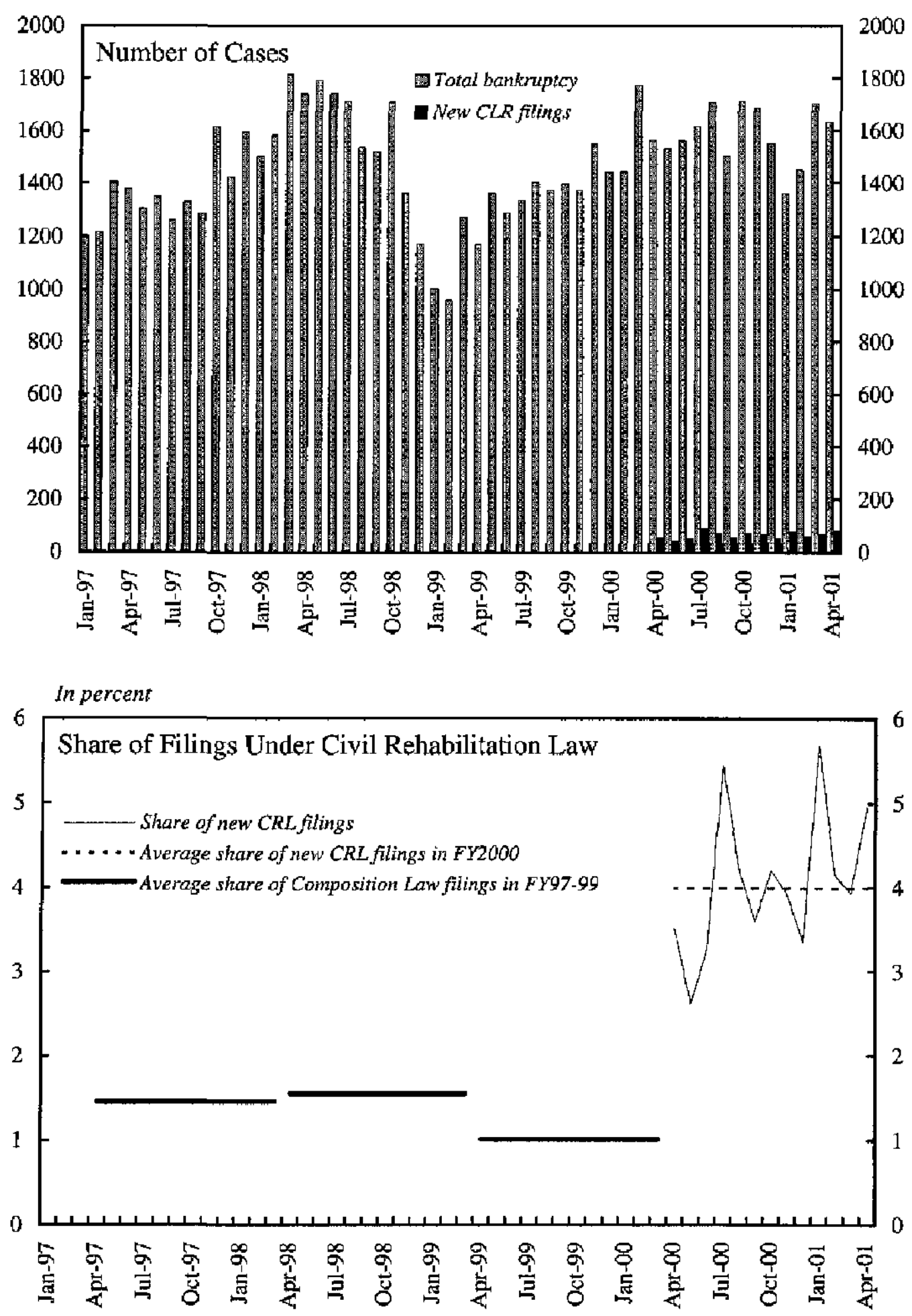

Source: Teikoku Databank, Ltd. 
- The "Accounting Big Bang" has entered its last stage, with mark-to-market (MTM) standards being applied to all securities holdings. Following the introduction of consolidated accounting in FY1999 and the application of MTM standards for marketable securities held in trading accounts and employees' retirement benefit liabilities in FY2000, securities held for investment purposes (including cross-shareholding) will have to be valued at market prices from FY2001. In addition to a general improvement in market discipline, this measure is expected to contribute to a further unwinding of cross-shareboldings, a process that has been underway during the last fiscal year.

\section{Regulatory Reform}

6. The Japanese approach to regulatory reform continued to be guided mainly by the Regulatory Reform Committee, which had provided the basis for the government's renewed comprehensive three-year deregulation agenda (FY1998-2000) in $2000 .{ }^{16}$ Overall, about three-quarters of the items in the agenda were fully implemented by the end of March $2001 .{ }^{17}$ Besides a shift in the regulatory approach from prior approval to retrospective supervision, that has gradually been implemented, a number of major reforms have been introduced.

- The remaining agenda in the "financial Big Bang" has been mostly put into effect. The wide-ranging reform in the financial sector was largely completed with the elimination of the barrier between banking and insurance by means of using subsidiaries and holding companies (October 2000); the legislation to allow the transformation of stock exchanges into equity corporations (December 2000); the permission to let banks sell insurance products over their counters (April 2001); and the removal of restrictions on domestic insurance companies to enter "third sector insurance" which includes insurance on medical care, cancer, and nursing care (January 2001 for life insurers and July 2001 for non-life insurers).

- The revision of the Commercial Code allowing corporate splits became effective in April 2001. Firms have started to use the scheme as a central part of their restructuring efforts, for example by creating a new corporate structure under a holding company by splitting the existing company into new firms along functional lines.

\footnotetext{
${ }^{15}$ The Regulatory Reform Committee provided recommendations to the government on the reform agenda each year, on which the government based its revision of the three-year program. The committee was dissolved in March 2001, at the expiration of its three-year term, after its final recommendations were reflected on the new three-year program through 2003.
}

${ }^{17}$ A total of 95 percent of the 1,268 item agenda has been either fully or partially completed. 
- The section in the Antimonopoly Aet exempting operations regarded as natural monopolies - such as those in the transportation, electricity, and gas industries-has been abolished (as of June 2000). The legislation followed efforts in past years to reduce the number of exemptions.

- The supply-demand adjustment clause has been eliminated in a number of transport industries to increase competition, ${ }^{18}$ The barriers to business entry and exit were removed for passenger water transport (October 2000) and port shipments (November 2000 ), while regulations on prices were also relaxed. Similar liberalization in the remaining industries, such as commercial bus and taxi services, will be put into effect by the end of FY2001, based on a bill approved in May 2000.

- Measures have been taken in the telecommunications industry to allow for greater flexibility in network construction. For example, in August 2000, service providers with own lines were permitted to sell their lines to other operators.

- To protect consumers from inappropriate marketing, the new Consumer Contract Law was established to form a general rule on economic transactions (April 2001).

- Administrative requirements for imports have been streamlined. Measures were taken to rationalize import-related administrative procedures, including the introduction of a simplified application system in March 2001, to allow importers under certain conditions to receive shipments before tariff payments.

7. A new three-year program carrying $\mathbf{5 5 4}$ items in $\mathbf{1 5}$ areas was formulated at the end of the FY2000. ${ }^{19}$ The program called for a strategic and comprehensive approach to address outstanding issues. It place a renewed focus on selected areas such as IT, medical care, social welfare, education, environment, and Jabor. New additions to the list include:

- Reviewing the allocation of broadband frequencies with a view to accelerating the penetration of high-speed Internet and reviewing the structure of NTT group in case competition is not enhanced;

- Continuing the discussion on increasing the number of lawyers - at present, a ceiling of only 1,000 is set on the number of lawyers qualifying each year; and

\footnotetext{
${ }^{18}$ One of the major barriers to entry in highly regulated industries, such as transportation, power, and telecommunications, has been the so-called "supply-demand adjustment clause." The government estimated the appropriate level of service suppliers against the estimated level of demand, and limited the number of operators accordingly through licensing. However, this restriction has been abandoned in most of the sectors in recent years.

${ }^{19}$ The new three-year program integrated the recommendations of the former Regulatory Reform Committee with items from other reform initiatives such as the revised Action Plan for Economic Structure Reform (December 2000) and e-Japan Priority Program (March 2001), as well as opinions from various quarters.
} 
Allowing banks to operate trust businesses.

8. The Council for Regulatory Reform was established under the new Cabinet Office in April 2001 to replace the former Regulatory Reform Committee so as to have greater authority in leading other government agencies in the reform process. While Japan's past approach to reform has been characterized as piecemeal, the new organization is expected to exert sufficient authority to draw out and implement more comprehensive plans, for example in social welfare programs. It will also monitor the progress of the enforcement of the three-year program.

\section{Administrative Reform}

9. Following a series of legislation approved in June 1998, July 1999, and December 1999, a large-scale reorganization of the central government took place on January 6, 2001:

- The number of principal ministries and offices has been reduced from 23 to 13 through mergers, with a view to streamlining the central government organization and to enhancing the Prime Minister's leadership (Box V.2). The newly created Cabinet Office has been placed above other ministries in the organizational chart, with a view to giving it a better control over comprehensive policy formulation.

- $\quad \mathbf{5 7}$ government business operations have been detached as independent administrative institutions (IAIs) to reduce government involvement in economic decision-making and enhance efficiency. ${ }^{20}$

- The number of central government employees is to be reduced by 25 percent by FY2009 following a Cabinet Decision in April 1999 that accelerated the initiative stated in the 1998 law. The scheme calls for a cut of about 550,000 central

20 IAIs were modeled after the "agencies" introduced in the United Kingdom in 1988 to streamline the government. An IAI is independent from the government and provides public services that need not be provided directly by the government, but may need some public sector involvement--e.g., museums, research institutes, and colleges. It has greater freedom in its organization and resource allocation, compared to the past when it operated as a branch of the government, which is expected to result in increased efficiency. An additional five agencies together with some national health institutions will join the list by 2004 . 


\section{Box V.2. Reorganization of Central Government}

The number of the central government ministries and agencies was reduced from 23 to 13 on January 6, 2001, following the agenda stipulated in the Basic Law for Government Reform in June 1998 and succeeding laws on the specifics in July and December 1999.

Former organization

New organization

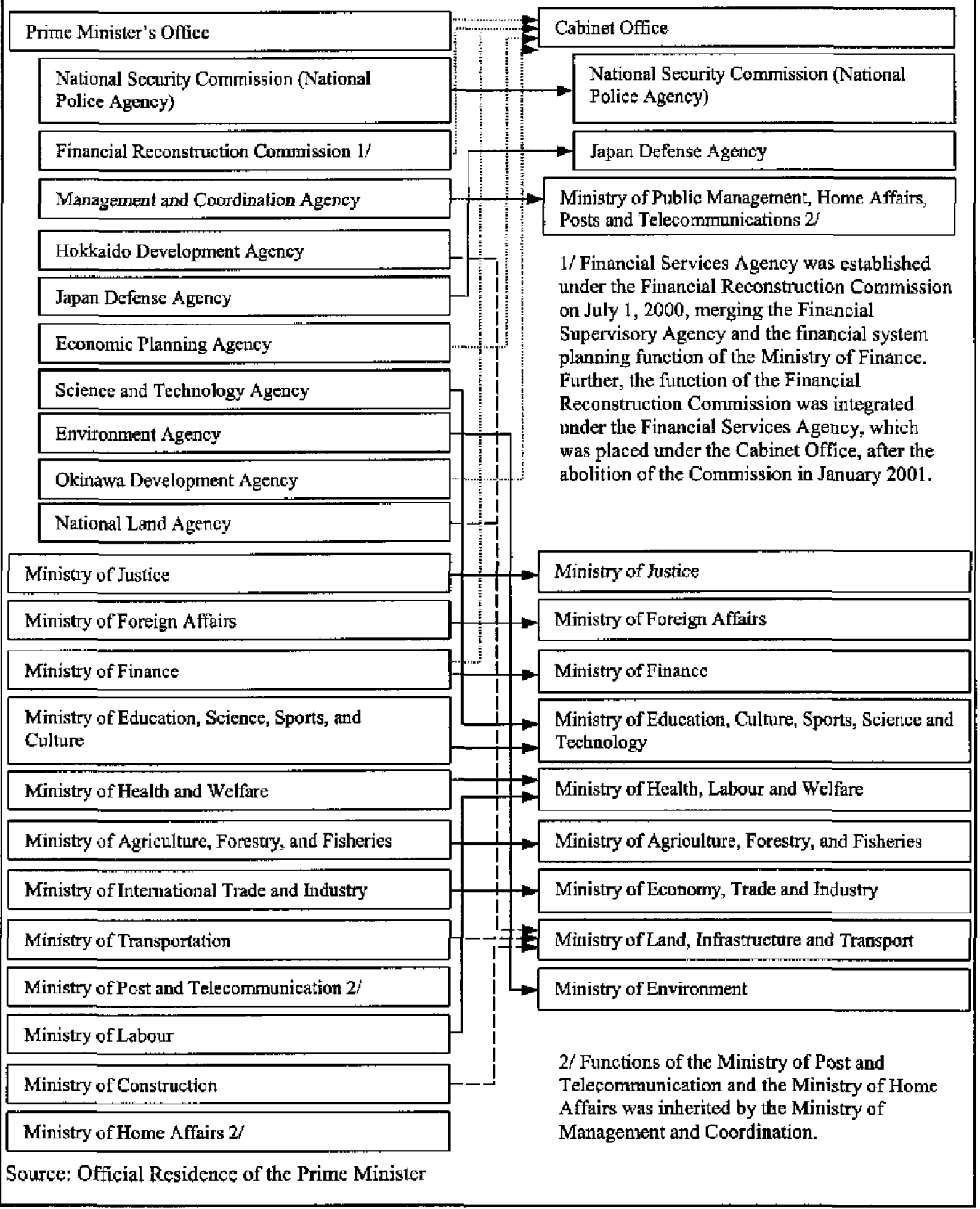


government officials over ten years, of which two-fifths will be cut through orderly reduction plans and the remainder through the separation of LAIs. ${ }^{21}$

10. To propel administrative reform beyond the central government reorganization, the government is currently fleshing out further reform targets for the next 5 years. A new position was created in the Cabinet to oversee the area of administrative reform, with a new supporting office attached to the Prime Minister's Secretariat. Special emphasis was placed on the following issues:

- The efficiency of the public service is to be raised through changes in the remuneration structure and stepped-up training. Based on a report released in June 2001, this includes such initiatives as: introducing performance-based pay and promotion systems for public servants; enhancing personnel exchange with the private sector; and strengthening the restrictions on the re-employment of public servants at private firms.

- In line with fiscal consolidation and FILP reform, public enterprises with special legal status (77 tokushu-huojin and 86 ninka-houjin), which are responsible for a large share of public sector expenditures, will ultimately be closed, privatized, or transformed into IAIs. ${ }^{22}$ Several institutions, including the Honshu-Shikoku Bridge Authorities and the Japan Highway Public Corporation, have been cited as examples in need of major reform. A review of their operations (preliminary results of which were reported in June 2001) will be the basis for a consolidation plan expected by the end of the year. ${ }^{23} \mathrm{~A}$ law requiring the completion of reform by end-FY2005 passed the Diet in June 2001.

${ }^{21}$ The total figure does not include those 300,000 employees of the postal insurance, savings, and services operations who will be transferred to a public corporation in 2003.

${ }^{22}$ A tokushu-houjin is defined as a corporation with special legal purpose established through a special incorporation process (e.g., Japan Highway Public Corporation, NTT, and Japan Railway Companies). Individual ministries establish and supervise such entities with the approval by the Ministry of Public Management, Home Affairs, Posts and

Telecommunications (MPHPT). A ninka-houjin, on the other hand, is defined as an institution with special legal purpose established through an ordinary incorporation process in the Commercial Code, followed by government authorization (e.g., Japanese Red Cross Society, Japanese Institute of Certified Public Accountants, etc.). Tokushu-houjin and ninkahoujin collectively received $¥ 71 / 2$ trillion of subsidies and handled $¥ 241 / 2$ trillion of FILP operations in FY2001.

${ }^{23}$ The Prime Minister called for the closure of the Japan National Oil Corporation ahead of the formulation of the broader consolidation plan at the year-end, to act as a model case. Its operations include managing oil reserves and extending loans to private oil developers, and are funded by fiscal transfers (subsidies exceeded $¥ 360$ billion in FY 2001 ). 
A comprehensive review of the operations of authorized non-profit organizations (koueki-houjin) that operate as agents for the government was completed in April 2001. ${ }^{24}$ Directions are to be formulated by the summer of 2001 to eliminate the operations that unjustifiably restrict private sector businesses or fail to use public: funds efficiently. An implementation plan is to be produced by the end of FY2001.

11. The law on information disclosure by the government became effective in April 2001 to improve public access to government information. The law is expected to put increased pressure on the efficiency of government operations.

\section{Finally, legislation to mandate policy reviews for individual ministries was} approved by the Diet in June 2001. The law requires the evaluation of policy measures so as to improve accountability and efficiency of specific policies. Policy reviews are to be conducted at various stages of policy formulation and implementation by individual ministries (with assistance from third parties including academics), reinforced by the review of MPHPT which will further run comprehensive evaluations across ministries based on uniform and objective standards.

\section{E. Information Technology Issues}

13. In recognizing the critical role of IT in the shift to a knowledge-based economy, the promotion of IT has emerged as one of the main pillars of the government's political agenda. A basic strategy for IT policy, released by the IT Strategy Council in November 2000 , formed the basis for further policy developments in this area. ${ }^{25}$ Supported by specific legislation and the IT Strategy Headquarters led by the Prime Minister, the strategy was refined into the government's "e-Japan Priority Policy Program" in March 2001. 26 The program identified the necessary policy steps to create a society equipped with an advanced information and telecommunications network, and established a set of goals with defined the timeframes. The areas emphasized in the program include the following:

${ }^{24}$ A koueki-houjin is a non-profit organization for public purposes. They enjoy preferential tax treatment on the non-profit operations. There are currently about 26,000 such organizations registered. About 1,000 of them operate as agents for the government based on specific laws (e.g., nationally authorized safety inspections and certified proficiency examinations), some of which receive budgetary transfers.

${ }^{25}$ The IT Strategy Council consisted of 20 private sector representatives, including business leaders and leading academics.

${ }^{26}$ The IT Basic Law, enacted in January 2001, identified the need for Japan to move toward an advanced information network society, and called for the formulation of an action plan. It also required the establishment of the IT Strategy Headquarters headed by the Prime Minister and composed of all cabinet members and a number of private sector representatives. 
- An advanced information network is to be provided within 5 years by promoting higher competition in the telecommunications industry and reducing the constraints in constructing optical fiber networks.

- In order to build the skills necessary to achieve broad-based use of the Internet within 5 years, education and investment in human resource are to be upgraded. The government also plans to promote the acquisition of IT skills in schools and seminars, and the formulation of TT-related human capital is to be advanced through university reforms and imports of foreign engineers.

- A user-friendly e-commerce market is to be established by 2003 , including by adapting existing regulations; introducing new rules to cope with issues intrinsic to etransactions; and ensuring appropriate protection of intellectual property.

- An e-government is to be established by 2003, with many administrative processes adapted to electronic format.

- To guarantee network safety and establish public confidence by 2005 , measures will be taken to protect individuals' private information-starting with the bill on private information currently being discussed in the Diet-and improving the technology on secure coding.

\section{F. Priorities for the Remaining Reform Agenda}

14. While the government has identified a broad reform agenda to implement in the coming years, progress in a number of areas will be crucial to boosting long-term growth prospects:

- A reduction in telecommunications charges could be key to the expansion of IT usage in Japan. ${ }^{27}$ Although the recently approved bill has imposed new regulations on dominant operators to allow other operators' connection to their networks and to create intra group firewalls, an advisory body's recommendation to consider dissolution of NTT's holding company structure unless competition intensified was not legislated. Also, while the network connection charges will be reduced by 20 percent by 2002 and $22 \frac{1}{2}$ percent by 2003 from the level in 2000 , they will remain high by international standards.

- Further liberalization in the power industry, especially in distribution, could contribute to a decline in production costs. Despite its initial impact of bringing down electricity prices by up to 10 percent, the partial liberalization of large-customer retail business enforced so far (March 2000) may not be sufficient to meet the current target

${ }^{27}$ See Callen and Nagaoka, 2001, in the accompanying Selected Issues volume for a discussion on the low IT usage in Japan. 
of reducing electricity charges to an internationally comparable level by $2005{ }^{28}$ The next review of the current liberalization initiative planned for 2003 could be brought forward to allow a more accelerated approach to lower electricity costs.

- Greater flexibility in the labor market could improve the efficiency of resource allocation. ${ }^{29}$ While government policy is primarily targeted at job security and reemployment support, recent measures including the relaxation of restrictions on private job placement business and job dispatching business (temporary employment service) have not had large effects on improving the flexibility in the labor market. A stronger focus on customized and specialized retraining programs could increase human capital and lead to a more mobile labor force. Moreover, despite a rather liberal legal framework, existing case law has continued to effectively impose high barriers for corporate layoffs.

- An overhaul of the Commercial Code could improve corporate governance as well as accelerate restructuring efforts and raise corporate profits. Recent amendments to the Commercial Code (June 2001)-which liberalized the holding of treasury stocks and shortened the process of new share issues from 4 weeks to 2 weeks by simplifying registration processes - have eased restrictions on corporate finance, but more deep-reaching measures are required. More comprehensive changes to the Code currently under discussion would lead to a greater empowerment of shareholders, aimed at improving efficiency and profitability. The issues being discussed include the introduction of mandatory external board members; clear separation of executive and auditing functions and removal of statutory auditors; further liberalization of stock options; and permission to use IT for sharebolders meetings.

- Progress with structural reform in the area of agriculture remains slow. As reflected in the imposition of preliminary safeguard measures on selected products in the spring of 2001, the competitiveness of agricultural products is losing ground to foreign imports. More generally, tariff peaks on certain agricultural products remain very high. In addition, while recent changes in land ownership regulations (enacted in March 2001) allow certain equity corporations to own farmland and price subsidies on agricultural products are being shifted to income subsidies, the consolidation of farmlands by efficient agricultural agents that is necessary to benefit from economies of scale is yet to be seen.

\footnotetext{
${ }^{28}$ The Action Plan for Economic Structure Reform of 1997 initially aimed to meet the target by 2001 , but the timeframe was extended in the revised action plan in December 2000 .

${ }^{29}$ See Callen and Nagaoka, 2001, in the accompanying Selected Issues volume for a discussion on the labor market rigidity.
} 


\section{References}

Japan Fair Trade Commission, 2000, "How the Japan Fair Trade Commission Ensures a Robust Economy," September.

Levy, Joaquim, 2000, "Reform of Japan's Insolvency Laws," Post Bubble Blues-How Japan Responded to the Asset Price Collapse, IMF.

Management and Coordination Agency, 2000, Kisei Kanwa Hakusho (White Paper on Deregulation), December (in Japanese).

Ministry of Economy, Trade and Industry, 2001, Tsusho Hakusho 2001 (White Paper on International Trade 2001), pp. 39-63, May (in Japanese; English version forthcoming).

Nomura Securities Financial Research Institute, 2001, "2000 Nen no Nihon Kigyou ni Kanren suru M\&A no Doukou (Development of M\&A Concerning Japanese Companies in 2000)," Nomura Securities Co., Ltd., January (in Japanese).

Teikoku Databank, 2001, "Minji Saisei Hou Sekou 1 Nen no Shinsei Doukou Chousa (Survey on the Filings Under the Civil Rehabilitation Law After I Year of Enforcement)," April (in Japanese). 


\section{VL. Trade Policy and Economic Assistance ${ }^{1}$}

1. Over the past year, Japan maintained its traditional emphasis on pursuing further trade liberalization through the WTO framework, while at the same time initiating talks on bilateral free trade agreements.

- While Japan's trade regime is relatively open according to a number of indicators, there remain barriers in several areas. ${ }^{2}$ The average tariff rate on imports is relatively low by global standards, positioned between the U.S. and E.U.

(Table VI,1). Nevertheless, very bigh tariffs and non-tariff barriers on imports of certain products imply that markets for some agricultural products remain relatively closed, mainly reflecting official concerns over food security against the background of a very low selfsufficiency rate. ${ }^{3}$ More generally, the complexity of the tariff structure (including the use of

\begin{tabular}{|c|c|c|c|}
\hline \multicolumn{4}{|c|}{$\begin{array}{c}\text { Table VI.1. Simple Average Applied } \\
\text { Tariffs, } 2000\end{array}$} \\
\hline & Japan' & U.S. $^{2}$ & E.U. $^{2}$ \\
\hline & \multicolumn{3}{|c|}{ (In percent) } \\
\hline Total & 6.5 & 5.7 & 6.9 \\
\hline WTO agriculture & 18.2 & 11.0 & 17.3 \\
\hline WTO nonagricutlure & 4.0 & 4.7 & 4.5 \\
\hline Petroleum & 6.5 & 2,3 & 2,9 \\
\hline \multicolumn{4}{|c|}{ Source: WTO Antual Report, 2001.} \\
\hline $\begin{array}{l}{ }^{1} \text { As of } 2000 . \\
{ }^{2} \text { As of } 1999 . \\
{ }^{3} \text { Excludes petroleum. }\end{array}$ & & & \\
\hline
\end{tabular}
non-ad valorem tariffs on agricultural products), time-consuming applications, private sector distribution practices, and different standards and units from exporting countries, continue to create difficulties for exporters to Japan (WTO, 2000, and Nicoletti, et al, 2000).

- Japan continued to support a comprehensive approach for the new WTO round. ${ }^{4}$ It maintained its stance that places the WTO at the center of the

\footnotetext{
${ }^{\text {I }}$ Prepared by Takashi Nagaoka (ext. 37613),

${ }^{2}$ An international comparison by the OECD ranked Japan $15^{\text {th }}$ among 21 OECD countries in terms of openness in trade and investment, mainly due to discriminatory procedures and ownership barriers (Nicoletti, Scarpetta and Boylaud, 2000).

${ }^{3}$ Notwithstanding the dismantling of QRs, some agricultural imports are still virtually blocked by very high tariff rates of above 500 percent. Meanwhile, Japan's food selfsufficiency rate on a caloric basis has declined from 80 percent in 1960 to below 40 percent in 1999 (the lowest among OECD countries); on a grain basis, domestic production accounted for 27 percent of consumption in 1999 (second lowest).

${ }^{4}$ Japan is among a group of countries that advocate an approach that will include both the "Built-in Agenda" for agriculture and services from the Uruguay Round and other areas such as investment, competition, environment, and anti-dumping.
} 
trade liberalization framework, and maintained its commitment to work toward an early launch of a new round.

- Meanwhile, Japan opened negotiations with Singapore in early 2001 to conclude an Economic Partnership Agreement (EPA) by year-end. The agreement will be wider in scope than a free trade agreement (FTA), covering mutual certification agreements and R\&D cooperation, in addition to free trade of goods and services. It is expected that it will provide a model for similar bilateral agreements in the future. Negotiations now underway with Korea and Mexico on investment agreements may become platforms for future FTAs or EPAs with these countries as well.

- Against a rapid increase in imports, Japan introduced preliminary WTO safeguard measures on selected products for the first time in April 2001. While still reviewing the full imposition of safeguards, the authorities have enforced provisional tariff quotas on three agricultural products to avoid what they perceive as irrecoverable damage to these industries. ${ }^{5}$ The government and the industries concerned need to formulate credible restructuring plans by November, when the current 200-day limit expires, if the full safeguard measures are to be enforced.

2. A number of important steps have been taken over the past year in line with international efforts to assist developing countries.

- As the chair of the Okinawa G7 Summit, Japan led the move toward accelerated implementation and expansion of the HIPC debt relief initiative. Following its full commitment to debt relief regarding claims outside ODA in April 2000, Japan led an initiative among the G7 countries to expand the commitments to qualified commercial claims at the Okinawa Summit in July. The G7 countries also agreed on targeting 20 HIPCs to reach decision points by the end of $2000 .^{6}$

- Japan has improved its duty- and quota-free access of exports from least developed countries (LDCs) to its markets. Effective April 2001, the number of LDCs was expanded from 42 to 46 and 352 industrial products were added to the list of items eligible for preferential treatment (the " 99 percent initiative on industrial tariffs"). However, there was no expansion of preferential treatment on agricultural products, some of which are protected by very high tariff rates.

- Japan remained the world's largest provider of ODA in 2000 at about $\$ 13$ billion, or 0.27 percent of GDP, with a very high untied ratio by global

\footnotetext{
${ }^{5}$ The three agricultural products are: long onions; shiitake mushrooms; and tatami surfaces.

${ }^{6}$ Consequently, the initiative was extended to 22 HIPCs.
} 


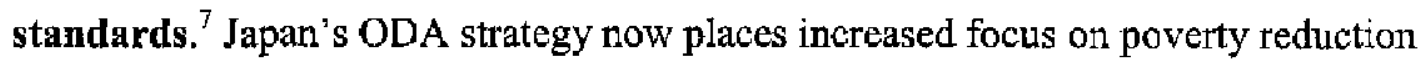
and social development, together with efficiency, effectiveness, and transparency in implementation. However, calls to review and reduce Japan's ODA budget have grown stronger over the past year, reflecting the weak economy and the growing need for fiscal reform. ${ }^{8}$

3. Japan has made progress over the past year toward the implementation of the Chiang Mai Initiative on bilateral swap and repurchase agreements. Substantial agreements were reached with Korea, Malaysia and Thailand on bilateral swap agreements by May 2001, and negotiations continue with Philippines and China.

\section{References}

Industrial Structure Council, 2001, 2001 Report on the WTO Consistency of Trade Policies by Major Trading Partners, Ministry of Economy, Trade and Industry.

Nicoletti, Giuseppe, Stefano Scarpetta and Olivier Boylaud, 2000, "Summary Indicators of Product Market Regulation with an Extension to Employment Ptotection Legislation," Economic Department Working Papers No.226, ECO/WKP(99)18, OECD, April.

World Trade Organization, 2000, "Trade Policy Review--Japan," November. ,2001, Annual Report, 2001, May.

\footnotetext{
${ }^{7}$ Japan's net ODA flows declined in FY2000 following the one-off increase in the contribution to the AsDB's Asian Currency Crisis Support Facility in FY1999. Discounting this element of $\$ 3$ billion, the underlying ODA flows continued to increase in FY2000. Japan scored the fourth highest untied ratio among DAC members in 2000, after Norway, Switzerland, and Portugal.
}

${ }^{8}$ Recently, the Finance Minister called for a 10 percent reduction in the ODA budget for FY2002. 